Dr.2542

\title{
ECONOMICS OF WIND ENERGY FOR IRRIGATION PUMPING
}

Final Report
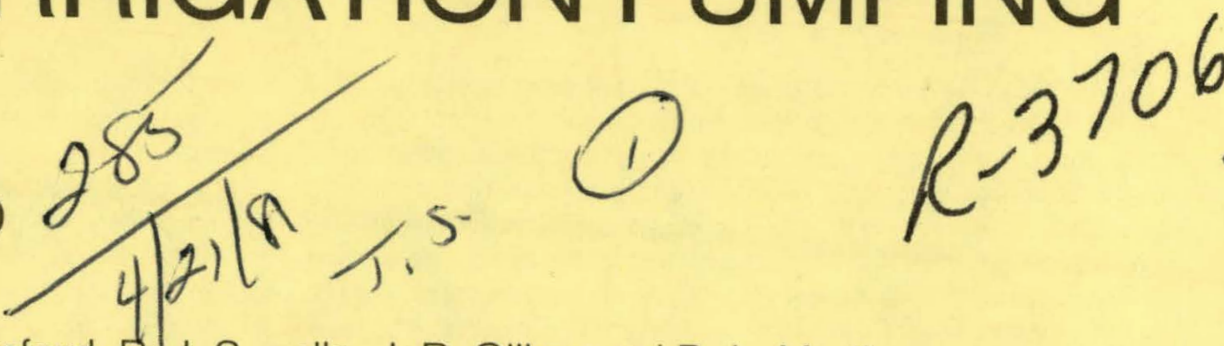
July 14,1980

R. R. Lansford, R. J. Supalla, J. R. Gilley, and D. L. Martin

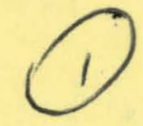

Southwest Research and Development Company Las Cruces, New Mexico

AIO1-168T20319

Prepared by

U.S. Department of Agriculture Science and Education Administration Agricultural Research

Prepared for U.S. Department of Energy Federal Wind Energy Program Interagency agreement: EX-76-A-29-1026

Report No. DOE/SEA-7315-20741/81/2 


\section{DISCLAIMER}

This report was prepared as an account of work sponsored by an agency of the United States Government. Neither the United States Government nor any agency Thereof, nor any of their employees, makes any warranty, express or implied, or assumes any legal liability or responsibility for the accuracy, completeness, or usefulness of any information, apparatus, product, or process disclosed, or represents that its use would not infringe privately owned rights. Reference herein to any specific commercial product, process, or service by trade name, trademark, manufacturer, or otherwise does not necessarily constitute or imply its endorsement, recommendation, or favoring by the United States Government or any agency thereof. The views and opinions of authors expressed herein do not necessarily state or reflect those of the United States Government or any agency thereof. 


\section{DISCLAIMER}

Portions of this document may be illegible in electronic image products. Images are produced from the best available original document. 
This report was prepared as an account of work sponsored by an agency of the United States Government. Neither the United States Government nor any agency thereof, nor any of their employees, makes any warranty, express or implied, or assumes any legal liability or responsibility for the accuracy, completeness, or usefulness of any information, apparatus, product, or process disclosed, or represents that its use would not infringe privately owned rights. Reference herein to any specific commercial product, process, or service by trade name, trademark, manufacturer, or otherwise, does not necessarily constitute or imply its endorsement, recommendation, or favoring by the United States Goverment or any agency thereof. The views and opinions of authors expressed herein do not necessarily state or reflect those of the United States Government or any agency thereof.

Report No. DOE/SEA-7315-20741/81/2, printed March 1981. 


\title{
ECONOMICS OF WIND ENERGY FOR \\ IRRIGATION PUMPING
}

by

Robert R. Lansford, Raymond J. Supalla,

James R. Gilley and Derrel L. Martin

Technical Completion Report

\author{
Submitted to: \\ Dr. R. Nolan Clark \\ USDA - SEA - AR \\ Great Plains Research Center \\ Bushland, Texas 79012 \\ Agreement No. 53-7330-9-139
}

by

Southwest Research and Development Company

1825 Imperial Ridgc

Las Cruces, New Mexico 88001

Robert R. Lansford, Coordinator

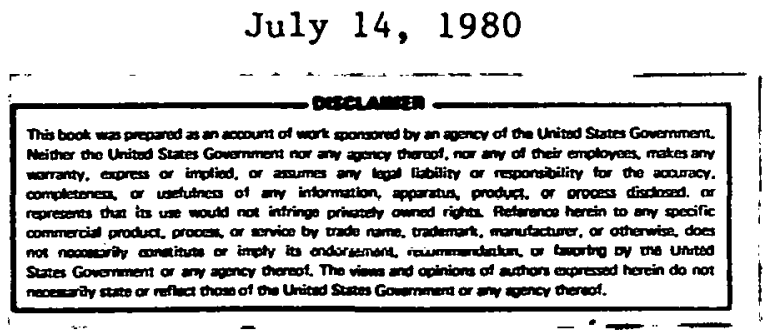

DISTRIBUTION OF THIS DOCUMENT IS UNLIAHIED 
THIS PAGE

\section{WAS INTENTIONALLY LEFT BLANK}


How much can an irrigator afford to invest in a wind turbine system for pumping irrigation water? This study addresses some of the economic questions associated with wind power as an energy source for irrigation under different situations in seven regions of the nation. The analysis will provide the United States Departments of Energy and Agriculture with target investment costs for wind turbines used for irrigation pumping; it also will provide policy makers with bases for adjusting taxes to make alternative sources of energy investments more attractive.

Three types of wind systems were considered for each of the seven regions. These regions were selected on the basis of the typical wind power available during the irrigation season and other factors, such as the length of the 1rrigation season and the quantity of irrigation water required. The regions were:

A. Kansas, Oklahoma, High Plains of Texas, High Plains of New Mexico, and Eastern Colorado.

B. Nebraska, South Dakota and North Dakota.

C. South Texas (Edwards Plateau) and Pecos Valley of New Mexico.

D. Southern Artzona and Southern California (primarily the Imperial Valley).

E. Snake and Columbia River Basins in Idaho, Oregon, and Washington.

F. Midwestern U.S. -- IIIInois and Indiana.

G. Southeastern U.S. -- Florida and Georgta.

The three types of wind powered irrigation systems evaluated for each region were: wind assist combustion engines (diesel, natural gas, propane pane), wind assist electric englnes, with or without sale of surplus electricity, and stand alone reservoir systems with gravity flow reservoirs.

The wind assist unfts essentially consist of vertical axis turbines connected to a conventional power source by means of an override clutch. conventional fuel consumption would be reduced when wind power is used, but 
the system would retain its ability to function without wind power, if necessary.

With the stand alone system, water would be pumped directly by wind into a reservoir for use when Irrigation water was needed. Outflow from the reservoir would be by gravity.

The approach used in the study of wind assist systems was as follows: (1) estimates were made of the average monthly amount of energy that can be harvested by a wind turbine under average conditions; (2) estimates were made of the economic value of the energy saved and/or sold; and (3) assessments were made of what irrigators in selected sttuations could afford to pay for wind turbines of different sizes. A similar approach was used for analyzing stand alone systems, with two additional steps: varlous combinations of reservoir and turbine sizes necessary to meet water demands were calculated for selected situations, and reservoir construction costs were estimated.

The amount that one could afford to invest in wind turbines was estimated for average conditions in each wind regton, under three energy price projections, for each major energy source, over a 20-year period. Discount rates of 7 and 10 percent were used in these analyses.

\section{Energy Savings}

The estimated amount of energy saved from assisting conventionally powered irrigation pumping units with wind turbines ranged from $13 \mathrm{k1lo-}$ watt hours per square meter of turbine size $\left(\mathrm{kWh} / \mathrm{m}^{2}\right)$ in Region $\mathrm{F}$ to 117 $\mathrm{kWh} / \mathrm{m}^{2}$ in Region $\mathrm{D}$. When the electricity that could be generated during non-1rrigation periods was added to irrigation savings, total estimated energy saved ranged from $565 \mathrm{kWh} / \mathrm{m}^{2}$ for Region A to $93 \mathrm{kWh} / \mathrm{m}^{2}$ for Reglon G.

\section{Economic Results and Conclusions}

\section{Wind Power Assist Without Sale of Surplus Electricity}

Results of the economic analyeis for wind assist systems indicate that wind turbines may be a viable alternative for irrigators who are using diesel or LP gas pumps in Region A. At the high energy price scenario, and with a 10 percent discount rate, diesel users in Region $A$ 
could afford to pay $\$ 132$ per square meter before tax savings, if they could not shift to any other conventional fuel. When tax consideration: are taken into account, a diesel user in the 25 percent tax bracket in Region A could afford to invest $\$ 161$ per $\mathrm{m}^{2}$ by claiming the business energy and investment tax credits. When the additional first-year depreciation and annual depreciation are included, the investment for wind turbines could be increased to $\$ 192$ per $\mathrm{m}^{2}$. LPG users in the same situation could afford to pay $\$ 106$ per $\mathrm{m}^{2}$ before the tax savings, and $\$ 154$ when all tax credits are claimed. Fstimated Investment values for all other wind assist situations are much lower (all less than $\$ 75$ per $\mathrm{m}^{2}$ ) at the medium energy price scenario. Thus, such systems would not be economically attractive unless production costs could be reduced well below the current cost of about $\$ 250$ per $\mathrm{m}^{2}$ for prototype units.

\section{Wind Power Assist With Sale of Surplus Electricity}

Wind assist with sale of surplus electriclty is more attractive economically than without it. Under this alternative, the investment per $\mathrm{m}^{2}$ for a wind turbine under the high energy price scenar1o, with a 10 percent discount rate, ranged from $\$ 217$ per $\mathrm{m}^{2}$ In Region $A$ to $\$ 21$ per $\mathrm{m}^{2}$ in Region G. With all tax credits claimed, the maximum investment per $\mathrm{m}^{2}$ for wind turbines ranged from $\$ 315$ in Region $A$ to $\$ 31$ in Region $G$ for a person in the 25 percent federal income tax bracket. Under the medium energy price scenario, the investment ranged from (-) $\$ 146 / \mathrm{m}^{2}$ in Region $G$ to $(-) \$ 2 / m^{2}$ in Region $A$, and when federal tax credits were included, it ranged from $\$ 212 / \mathrm{m}^{2}$ in Region $A$ to $(-) \$ 2 / \mathrm{m}^{2}$ in Region $G$. Investment values appear to be high enough in Region $A$ under both the high and medium energy price scenarios to merit serious considerations. In Region $B$, the investment values almost merit consideration under the 25 percent federal tax bracket, and they merit serious consideration under the 50 percent federal income tax bracket. In the other regions, the values do not appear high enough to merit serious consideration at this time.

\section{Stand Alone System}

The amount that one could afford to invest in wind turbines for a stand alone system was estimated for average conditions in each wind re- 
gion. Under the high energy price scenario, the fuel that would be replaced, the maximum before-tax investment value per $\mathrm{m}^{2}$ and the corresponding wind turbine sizes for each region are as follows: Region $A$, diesel, $\$ 702 / \mathrm{m}^{2}, 197 \mathrm{~m}^{2}$; Region B, diesel, $\$ 178 / \mathrm{m}^{2}, 326 \mathrm{~m}^{2}$; Region C, natural gas, $\$ 45 / \mathrm{m}^{2}, 694 \dot{\mathrm{m}}^{2}$; Region D, electricity, $\$ 129 / \mathrm{m}^{2}, 830 \mathrm{~m}^{2}$; Region E, electricity, $\$ 78 / \mathrm{m}^{2}, 628 \mathrm{~m}^{2}$; Region $\mathrm{F}$, gasoline, $\$ 91 / \mathrm{m}^{2}, 354 \mathrm{~m}^{2}$ and Region G, diesel, $\$ 143 / \mathrm{m}^{2}, 416 \mathrm{~m}^{2}$. Thus, when a high energy price scenario is assumed, stand alone wind systems appear to have reasonable potential for irrigators in Regions $A$ and $B$ who cannot shift to electricity or natural gas, cven when federal income tax deductions are not considered. When all federal incentives and taxes are deductcd, stand alone wind systems appear to have reasonable potential for irrigators using diesel and LPG in Region A, even under the low energy price scenario. If at least medium energy prices are expected, after tax, wind energy values look attractive for diesel and LPG users in Regions $A$ and B. Under the high energy price scenario, after tax, wind energy values for the diesel user in Region $G$ may also fall within the feasible range. Est1mated investment values for all remaining situations are well below the current cost of about $\$ 250$ per m for prototype wind turbine units.

\section{Other Considerations}

This study indicates that producere in several situations may find wind turbines a viable investment, espectally pruducers who must otherwise use diesel or LYG In Regions A and B. There are, however, additional considerations. 1) The results were based on average monthly wind data for broad geographical areas, and may not fit each Individual case. (A producer would find it desirable to ohtain daily or weekly wind energy values and compare wind energy available to needs for pumping); 2) The performance coefficlent of tho turbine may vary from the 20 percent used in this study; 3) There may be possibilities for modifylng irrigation and crop management practices to take greater advantage of wind power; and 4) The existence of state tax provisions not considered in the study may make wind energy more attractive in particular states. .

The above considerations clearly merit further investigation in view of the economic potential that wind energy for irrigation pumping appears 
0 have. What is provided in this study is essentially a first cut at estimating target investment values. Until more is known about the above factors, significant uncertainties regarding the economic value of wind systems will continue to exist. 


\section{THIS PAGE}

\section{WAS INTENTIONALLY LEFT BLANK}


EXECUTIVE SUMMARY . . . . . . . . . . . . . . . 111

LIST OF TABLES . . . . . . . . . . . . . . . . $x 1$

LIST OF FIGURES . . . . . . . . . . . . . . . x xi1

INTRODUCTION . . . . . . . . . . . . . . . . 1

Description of Study Regions ............ 2

Location and Quantity of Wind Power by Region . 2

Region Selection ............... 5

Irrigation Systems . . . . . . . . . . . 5

Wind-Powered Irrigation Systems . . . . . 5

METHODS AND PROCEDURES . . . . . . . . . . . . 11

Wind Power Available............... 11

Energy Saved .................... 12

Wind Assist Without Sale ......... 12

Wind Assist With Sale............ 14

Stand Alone System . . . . . . . . . . 14

Reservoir and Turbine Sizing . . . . . . . 16

Economic Analysis .. . . . . . . . . . . . 18

Energy Price Scenarios . . . . . . . . . . . 19

Breakeven Investment Values for Wind

Assist Systems ............. 20

Breakeven Investment Values for Stand

Alone System ................ 21

Effect of Taxes on Investment Values ..... 22

Typical Size and Cost of Wind Turbines . . . . . 23

RESULTS • . • . . . . . . . . . . . . . . 27

Amount of Energy Saved . . . . . . . . . . . 27

Amount of Surplus Electricty Available for Sale • . 27

Breakeven Instrument Values . . . . . . . . . . 27

Wind Assist Without Sale of Surplus

Electricity . . . . . . . . . . . 27

Wind Assist with Sale of Surplus Electricity . $\quad 31$

Stand Alone System ............ 33

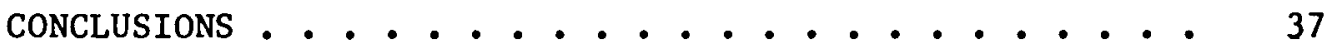

REFERENCES . . . . . . . . . . . . . . . 4 41

APPENDIX A - Turbine and Reservoir Sizing Analysis . . 43

APPENDIX B - Breakeven Investment Values, Wind Assist Without Sale of Surplus Electricity ... . 
TABLE OF CONTENTS (continued)

Page

APPENDIX C - Breakeven Investment Values, Wind Assist With Sale of Surplus Electricity . . . .

APPENDIX D - Breakeven Investment Values, Stand Alone System . . . . . . . . . . . . . . 
1 Wind power avallable and hours of turbine, operation by region . . . . . . . . . . . . . 15

Energy price by source and region, January, 1980 . 19

3 Adjustment factors for converting before-tax investment values to after tax values at different tax rates and depreciation schedules . . . . . . 24

Conversion sizes of turbines (square meters) to diameter (meters) to power leve1 at 10 meters per second .................... 24

5 Investment value per square meter for wind assist turbines by energy source and energy price scenario, by region . . . . . . . . . . . . . . 29

6 Investment values per square meter for wind assist turbines selling surplus electricity by energy price scenario . . . . . . . . . . . 32

7 Investment value per square meter for stand alone wind systems by region, energy source, and price scenario at 10 percent discount rate . . . . . . 34

A-1 Turbine and Reservoir Sizing Analysis for Region A . 44

A-2 Turbine and Reservoir Sizing Analysis for Region B . . 45

A-3 Turbine and Reservoir Sizing Analysis for Region C • . 46

A-4 Turbine and Reservoir Sizing Analysis for Region D . . 47

A-5 Turbine and Reservoir Sizing Analysis for Reginn E . . 48

A-6 Turbine and Reservoir Sizing Analysis for Region F • . 49

A-7 Turbine and Reservoir Sizing Analysis for Region G • . 50 
Mean annual wind power $\left(W / \mathrm{m}^{2}\right)$ estimated at $50 \mathrm{~m}$ above exposed areas. Over mountainous regions shaded areas) the estimates are lower limits expected for exposed mountain tops and ridges . . . . 3

Summer - average wind power $\left(W / \mathrm{m}^{2}\right)$ estimated at $50 \mathrm{~m}$ above exposed areas. Over mountainous regions shaded areas) the estimates are lower limits expected for exposed mountain tops and ridges . . . . 4

3 Location of wind energy regions . . . . . . . 6

$4 \quad$ Number of pumping units by source of energy and wind region .................... . 7

5 Number of pumping units by type of irrigation system by wind region .................... 8

6 Number of pumping units by size of pumping plant by region . . . . . . . . . . . . . . . 9

7 The potential amount of energy saved from using wind turbines for pumping irrigation and the amount of surplus electricity avatlable for sale from the use of wind turbines by region . . . . . . . . . 28

A-1 Turbine vs. Reservoir Size - Region $\Lambda$. . . . . . 51

A-2 Turbine vs. Keservolr Hize - Rquinn B, . . . . . 52

A-3 Turbine vs. Reservoir Size - Region C . . . . . . 53

A-4 Turbine vs. Reservoir Size - Region D . . . . . . . 54

A-5 Turbine vs. Reservoir Size - Region E . . . . . . 55

A-6 Turbine vs. Reservoir Size - Region F . . . . . 56

A-7 Turbine vs. Reservolr Size - Rugion C. . . . . . 57

B-1 Breakeven Investment value (1980 dollars). by turbine size for diesel by energy price scenario, wind assist without sale of surplus electricity, Region A . . . 60

B-2 Breakeven investment value (1980 dollars) by turbine size for LPG by energy price scenario, wind assist without sale of surplus electricity, Region A . . . 
B-3 Breakeven investment value (1980 dollars) by turbine size for natural gas by energy price scenarlo, wind assist without sale of surplus electricity, Reglon A. 62

B-4 Breakeven investment value (1980 dollars) by turbine size for diesel by energy price scenario, wind assist without sale of surplus electricity, Region B... . 63

B-5 Breakeven investment value (1980 dollars) by turbine size for natural gas by energy price scenario, wind assist without sale of surplus electricity, Region D. 65

C-1 Breakeven investment value (1980 dollars) by turbine size for electricity by energy price scenario, wind assist with sale of surplus electricity, Region A. .

C-2 Breakeven investment value (1980 dollars) by turbine size for electricity by energy price scenarlo, wind assist with sale of surplus electricity, Region B . .

C-3 Breakeven investment value (1980 dollars) by turbine size for electricity by energy price scenario, wind assist with sale of surplus electricity, Region C..

C-4 Breakeven investment value (1980 dollars) by turbine size for electricity by energy price scenario, wind assist with sale of surplus electricity, Region D. .

C-5 Breakeven investment value (1980 dollars) by turbine size for electricity by energy price scenario, wind assist with sale of surplus electricity, Region E . . 70

C-6 Breakeven investment value (1980 dollars) by turbine size for electricity by energy price scenario, wind assist with sale of surplus electricity, Region F . .

C-7 Breakeven inveslment value (1980 dollars) by turbine size for electricity by energy price scenario, wind assist with sale of surplus electricity, Region G • . 72

D-1 Breakeven investment value (1980 dollars) by turbine size and energy source, by energy price scenario, stand alone system, Region A . . . . . . . 73

D-2 Breakeven investment value (1980 dollars) by turbine size and cnergy source, by energy price scenario, stand alone system, Region B . . . . . . . . .

D-3 Breakeven investment value (1980 dollars) by turbine size and energy source, by energy price scenario, stand alone system, Region C . . . . . . . 75 
D-4 Breakeven investment value (1980 dollars) by turbine size and energy source, by energy price scenario, stand alone system, Region D . . . . . . . 76

D-5 Breakeven investment value (1980 dollars) by turbine size for electricity, by energy price scenario, stand alone system, Region E . . . . . . . . . 77

D-6 Breakeven investment value (1980 dollars) by turbine size and energy source, by energy price scenario, stand alone system, Region F . . . . . . . 78

D-7 Breakeven investment value (1980 dollars) by turbine size and energy source, by energy price scenario, stand alone system, Region G . . . . . . . . 79 
ECONOMICS OF WIND ENERGY FOR

IRRIGATION PUMPING

by

Robert R. Lansford, Raymond J. Supalla

James R. Gilley, and Derrel L. Martin

\section{INTRODUCTION}

In response to rapidly rising energy costs, farmers have begun looking at alternative systems for pumping irrigation water. Among the alternatives receiving increased attention are wind turbines. The adoption of wind power for irrigation is a choice of technique as well as an investment decision. Unlike more familiar choices of technique - whether or not to use new varieties and whether or not to purchase a more powerful tractor - the adoption of wind energy is subject to enormous technological and economic uncertainties. The technological uncertainties refer to performance characteristics of the wind power system -- how long will it last, what is its likely efficiency in converting wind energy into usable pumping energy, what maintenance costs are required, and so forth. The economic uncertainties refer to future costs, prices and financing: What is the likely cost of wind power systems; what are the likely costs of alternative fuels in the future; is Federal policy likely to equalize the costs of fuels on a BTU basis; what are loan-value ratios, interest rates, term of loan, or tax treatment associated with financing wind energy systems.

The purpose of this study was to address some of the abnve economic questions and thus reduce some of the uncertainties associated with wind power as an energy source for irrigation. More specifically, the principal objective of the study was to determine the maximum amount which irrigators in different situations could afford to invest in a wind turbine system for pumping irrigation water.

The results of the analysis will provide the U.S. Departmenta of Energy and Agriculture with target investment costs for wind turbines used for irrigation pumping, and potential users of wind turbines with a basis for deciding when and if they should invest in a wind powered 
system. The results could also be used by policy makers who are interested in adjusting tax policy to make alternative sources of energy that substitute for fossil fuels more attractive.

\section{Description of Study Regions}

The geographic regions analyzed in this report were selected based on the available wind power and the amount of irrigation. The wind power data were obtained from a Battelle study by Elliot (1977) and data concerning irrigation acreage, number of pumping plants, size of pumping plants, and method of irrigation were obtained from a 1979 irrigation assessment by Gilley (1980).

Location and Quantity of Wind Power by Region

The Great. Plains has the greatest potential for utilizing wind energy than of any region in the United States (Figure 1). Elliot (1977), estimates the Great Plains has a mean annual wind power rang1ng from 350 watts per square meter $\left(\mathrm{W} / \mathrm{m}^{2}\right)$ to over $500 \mathrm{~W} / \mathrm{m}^{2}$, at 50 meters above the ground. Other important U.S. irrigation regions have much less potent1al wind energy. Southern California, the San Joaquin and Imperial valleys, southern Arlzuna, the Snutheast and the Midwest have mean annual wind power of only $200 \mathrm{~W} / \mathrm{m}^{2}$ or 1ess. In Washington, Oregon, and Idaho, where large grnundwater irrigated areas exist, the average annual wind power is nearly $300 \mathrm{w} / \mathrm{m}^{2}$. In the Great Plains and the Southeast, the maximum wind power occurs in the spring; much of the Pacific States receive wind power in the winter months, with the exception of the San Joaquin Valley.

The Great Plains tend to have higher average wind power during the growing season. (May through September) than any irrigated region in the Unit.cd States, especially during the critical summer months, with 400 $\mathrm{W} / \mathrm{m}^{2}$ (Figure 2). The Pacific Northwest averages $200 \mathrm{~W} / \mathrm{m}^{2}$ during the summer, followed by Southern California and Arizona, with 100 to 200 $\mathrm{W} / \mathrm{m}^{2}$. The Midwest averages $150 \mathrm{~W} / \mathrm{m}^{2}$, and the Southeast irrigated areas range from 50 to $150 \mathrm{w} / \mathrm{m}^{2}$. Data 1 in Figures 1 and 2 were used on $1 y$ for regional delineation, not for wind power values for irrigation. 


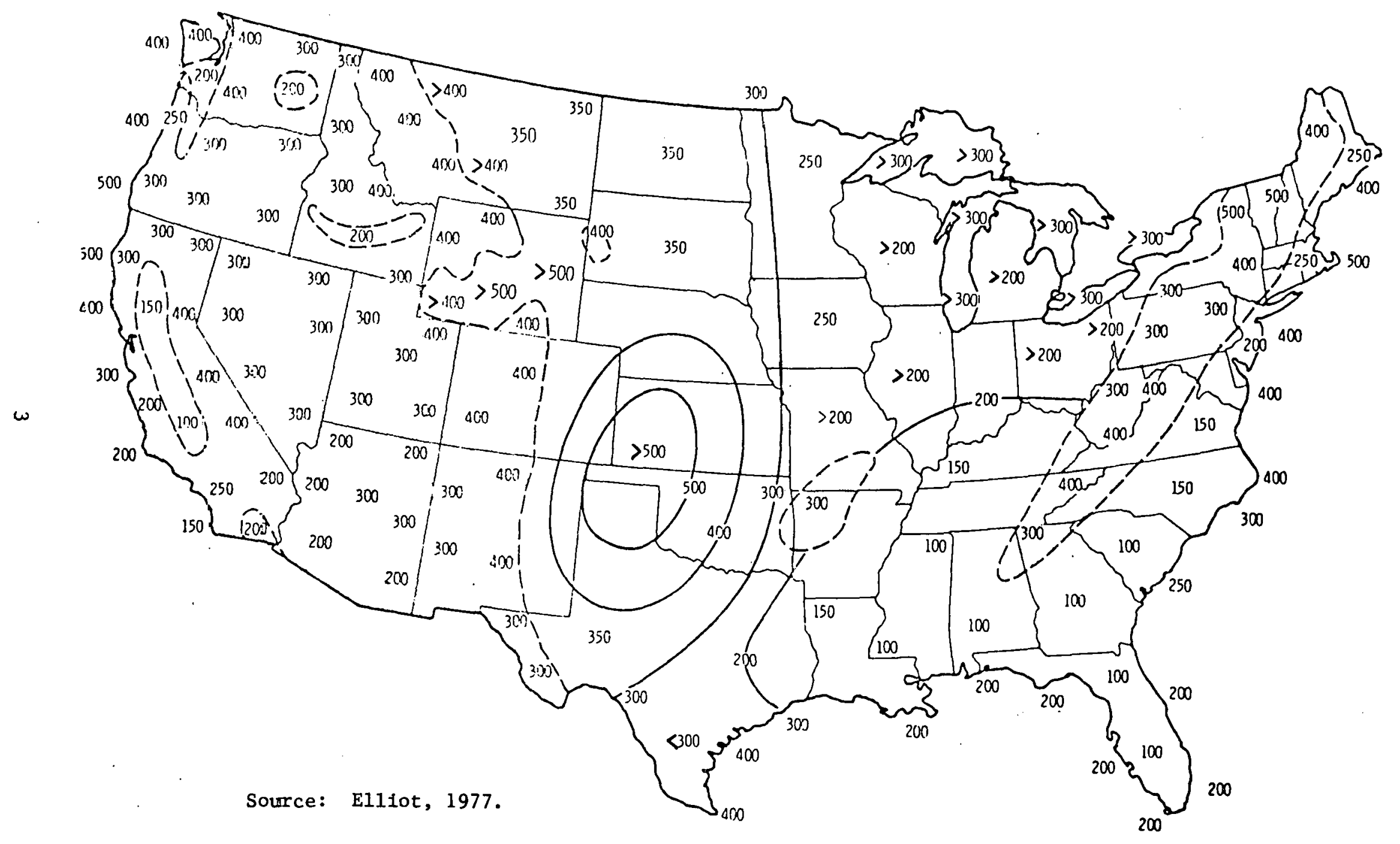

FIGJRE 1. Mean annual wind power $\left(\mathrm{W} / \mathrm{m}^{2}\right)$ estimated at $50 \mathrm{~m}$ above exposed areas. Over mountainous regions (shaded areas), the estimates are lower limits expected for exposed mountain tops and ridges. 


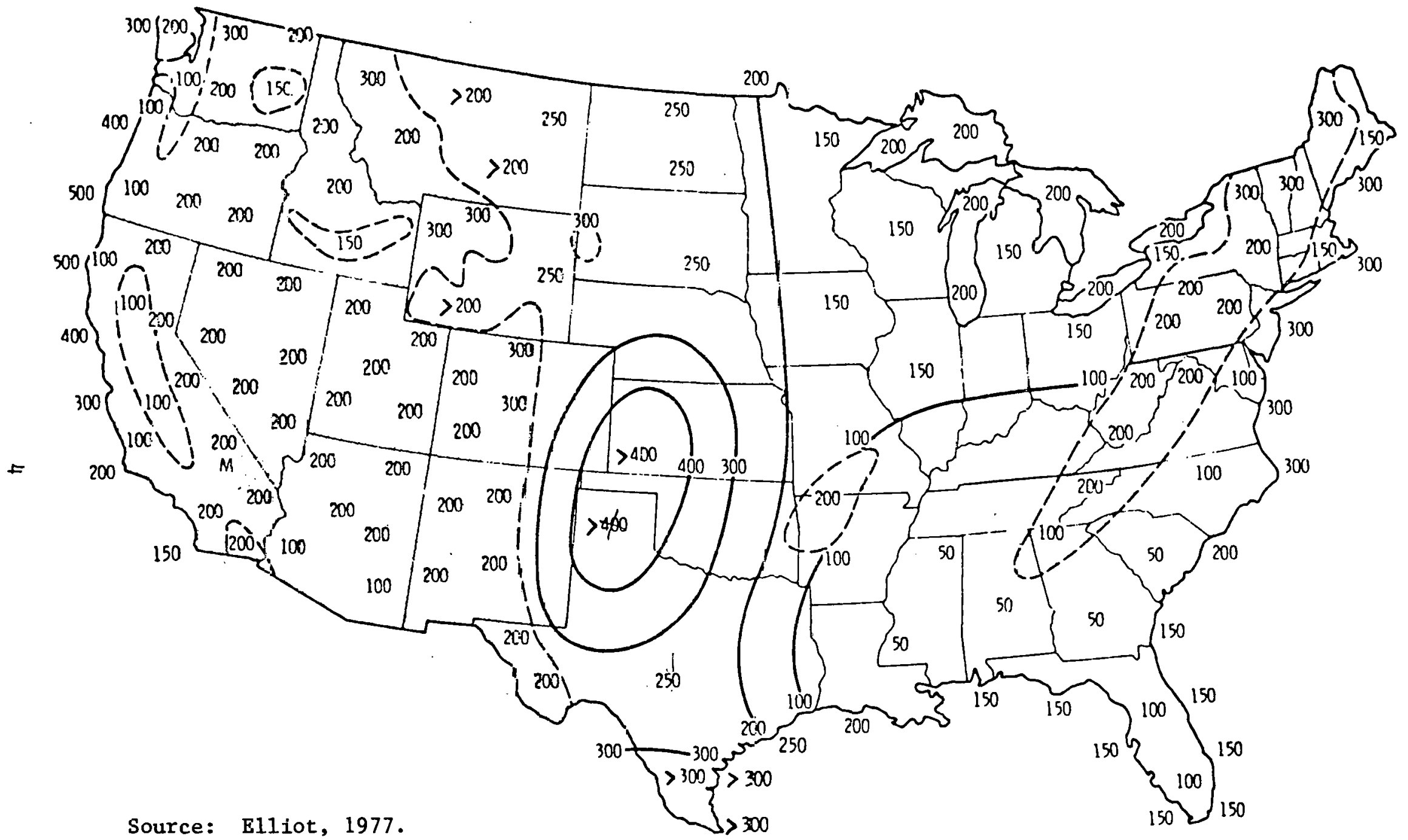

FIGURE 2. Summer--Average wind power $\left(\mathrm{W} / \mathrm{m}^{2}\right)$ estimated at $50 \mathrm{~m}$ above exposed areas. Over mountainous regions (shaded areas), the estimates are lower limits expected for exposed mountain tops and ridges. 
Typical wind power avallable during the Irrigation season was combined with other factors, such as the length of irrigation season, quantity of irrigation water required during the season, type of irrigation system, size of pumping plant, and type of fuel used for pumping irrigation water, as a basis for the selection of seven Wind Regions (Figure 3). They are:

\section{Wind Regions}

A. Kansas, Oklahoma, High Plains of Texas, High Plains of New Mexico, and Eastern Colorado.

B. Nebraska, South Dakota and North Dakota.

C. South Texas (Edward Plateau) and Pecos Valley of New Mexico.

D. Southern Arizona and Southern California (primarily the Imperial Valley).

E. Snake and Columbla River Basins in Idaho, Oregon, and Washington.

F. Midwestern U.S. -- I111nois and Indiana.

G. Southeastern U.S. -- Florida and Georgia.

\section{Irrigation Season}

March - October

Apr11 - September

March - October

A11 year

Apr11 - October

June - September

March - October

\section{Irrigation Systems}

The number of pumping units, by source of energy used to pump irrigation water, are presenter for each wind region in Figure 4. Only those sources of energy that represented 15 percent or more of the pumping units were included in the analysis. The number of sprinkler and surface irrigation plants by wind region is shown in Figure 5. The size distribution of the irrigation pumping plants in the seven regions is shown in Figure 6.

Wind-Powered Irrigatiun Systems

Four types of wind powered Irrigation systems were evaluated. They are: 



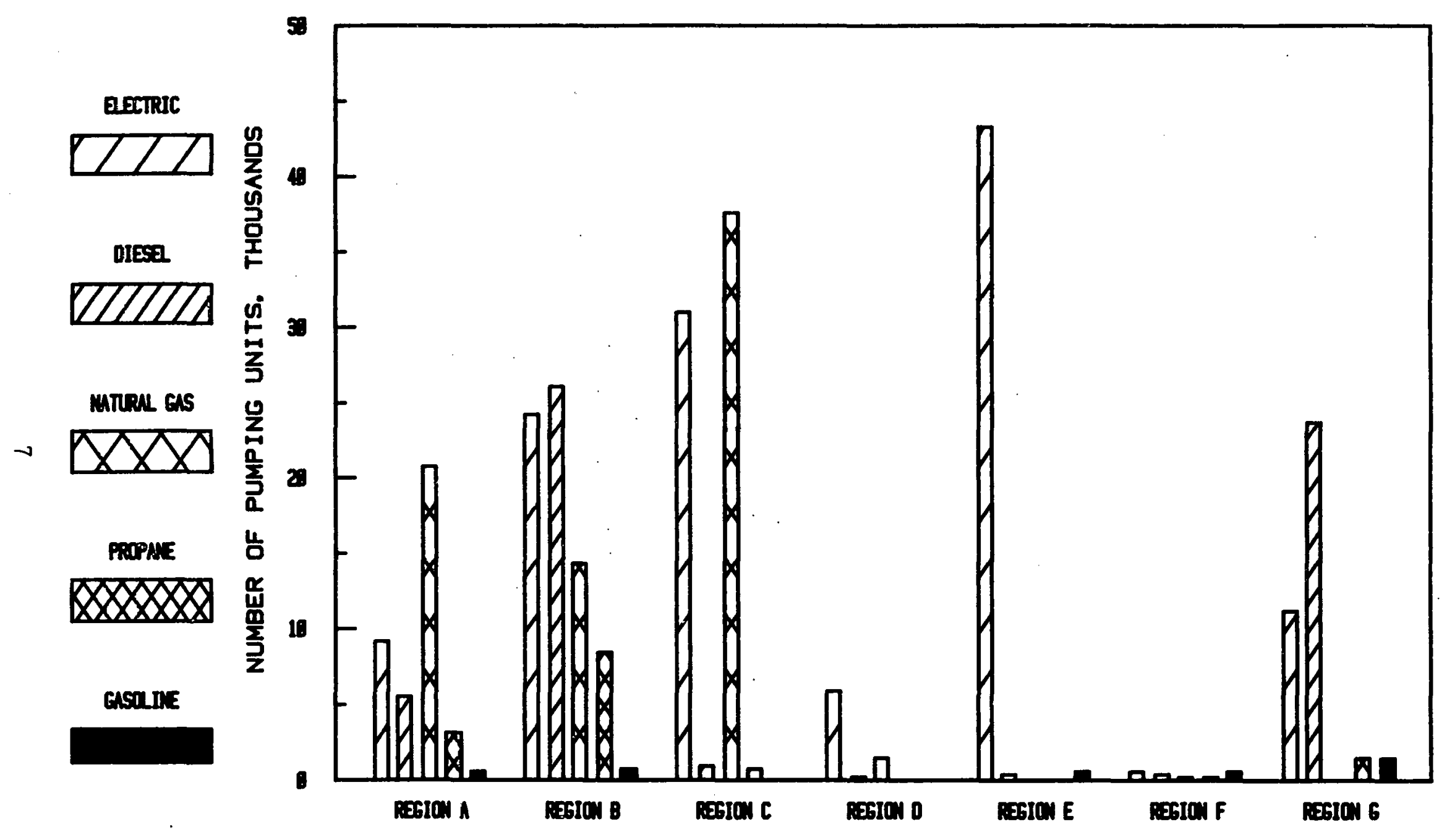

Figure 4. Number of pumping units by source of energy and wind region. 


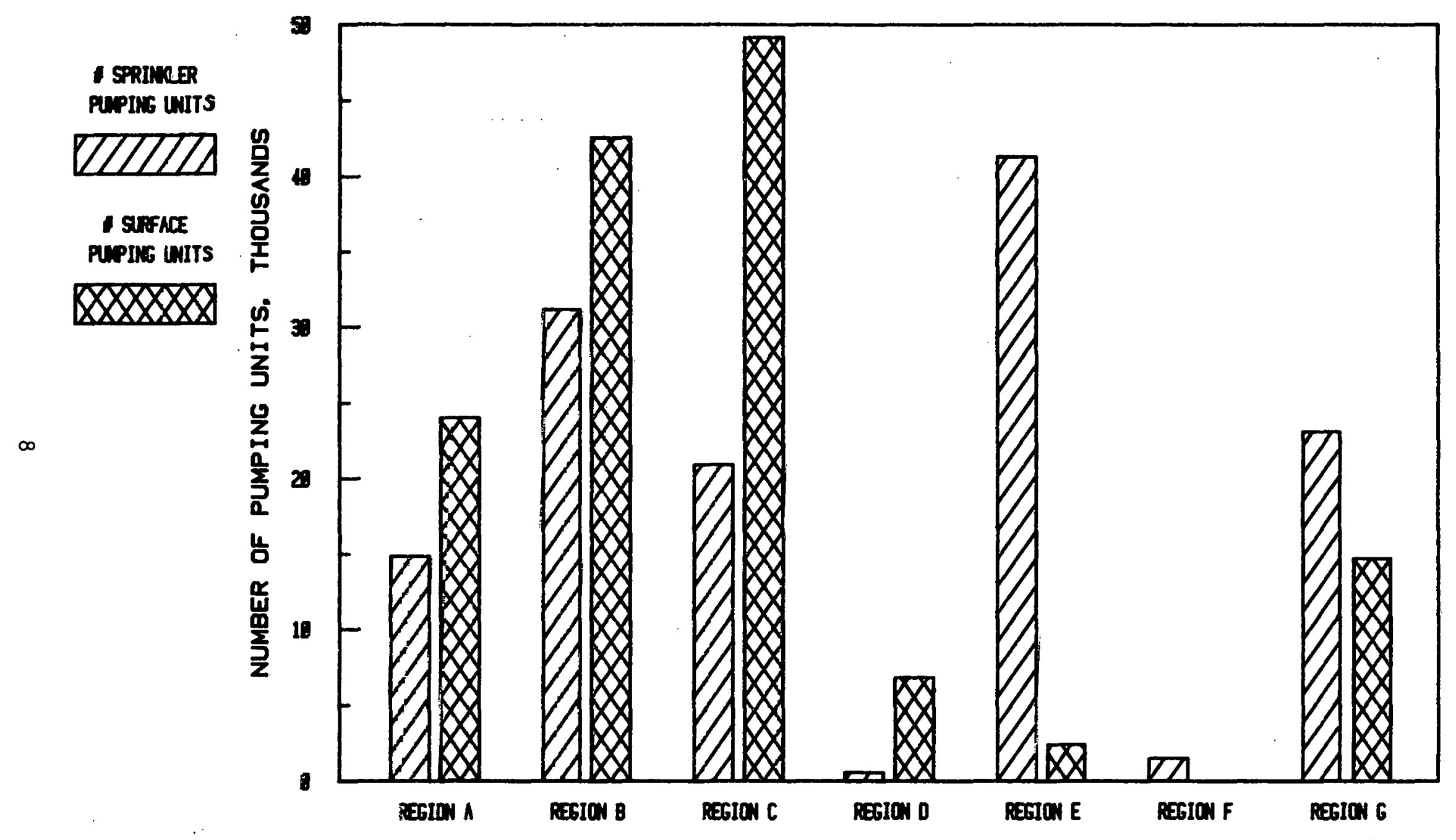

Figure 5. Number of pumping units by type of irrigation system by wind region. 


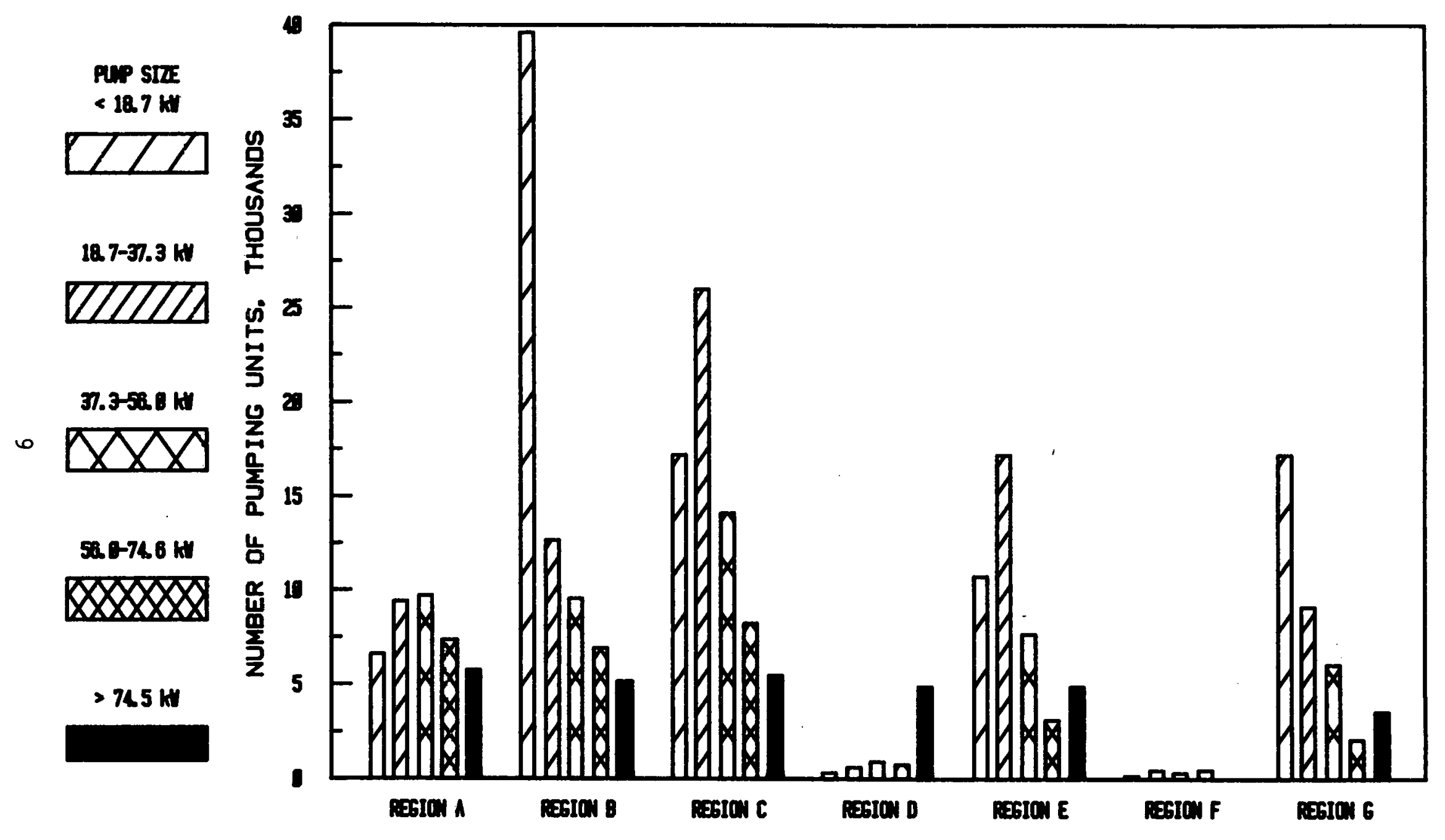

Figure 6. Number of pumping units by size of pumping plant by region. 
A. Wind assist combustion engines

1. Diese1

2. Natural Gas

3. Propane

4. Gasoline

B. Wind assist electric engines, without sale of surplus electricity

C. Wind assist electric engines, with sale of surplus electricity

D. Stand alone reservoir system with gravity flow reservoir 
The general analytical approach used in this study for wind assist systems involved four basic steps: (1) estimates of the amount of wind power available, (2) estimates of the amount of energy that can be harvested by a wind turbine under various conditions, (3) estimates of the economic value of the energy saved and/or sold, and (4) assessment of what irrigators in selected situations could afford to pay for different sized wind turbines. A similar approach was used for analyzing stand alone systems, with two additional steps: calculations of the various combinations of reservoir and turbine sizes necessary to meet water demands for selected situations, and estimates of reservoir construction costs.

\section{Wind Power Available}

The monthly wind power avallable at an elevation of 20 meters for the seven study regions was estimated using the wind data techniques from Reed (1979). The following data were available for each weather station: annual average power, the power at the average annual wind speed, the ratio of these two power values, and average monthly wind speed. These values were tabulated for the anemometer elevation of the particular weather station. Details regarding these data are given in Reed (1979).

The average monthly wind power $\left(P E_{i}\right)$ for a given weather station was calculated by use of the following formula:

$$
\mathrm{PE}_{1}=1 / 2 \circ\left(\mathrm{V}_{i}\right)^{3} * \operatorname{RATIO} * \mathrm{DENS}_{1} * \mathrm{TEMP}_{i}
$$

where: $\quad \mathrm{PE}_{i}=$ the average monthly power at the given anemometer elevation; $\mathrm{w} / \mathrm{m}^{2}$.

$\rho=$ the air density, $\mathrm{kg} / \mathrm{m} 3$.

$v_{i}$ - the average monthly wind speed at the given anemometer elevation, meters/second.

RATIO = the ratio of the average annual power to the power in the annual average wind speed. This value was assumed constant for all months. This correction converts power in the average wind speed to average power. 


$$
\begin{aligned}
\text { DENS = } & \text { the air density correction factor for weather } \\
& \text { station altitude (Reed, 1979). } \\
\text { TEMP }_{1}= & \text { the monthly air temperature correction factor } \\
& \text { for air density (Reed, 1979). }
\end{aligned}
$$

Average monthly wind power at 20 meters $\left(P_{1}\right)$. was calculated as:

$$
\begin{aligned}
& \mathrm{PE}_{\mathrm{i}}=(20 / \mathrm{X})^{3 / 7} \mathrm{PE}_{\mathrm{i}} \\
& \text { where: } \mathrm{X}=\text { the anemometer elevation in meters. }
\end{aligned}
$$

An elevation of twenty meters was selected because this is the USDA recommended height for rural turbines. These above assumptions were necessary to estimate average monthly wind power given the available . annual average wind power and average monthly wind speed data from Reed.

The above formula was used to estimate average monthly wind power for each weather station. The average monthly wind power from several weather stations within each of the seven wind regions were averaged to determine the monthly wind power for the selected region. For most regions, at least 10 weather stations were averaged to determine the theoretical avallable wind power available at 20 meters. The anemometry confidence code given by Reed and the proximity of the weather station to the irrigated area within the region were used to select the weather stalions included in the analysis.

\section{Energy Saved}

The amount of energy saved with a wind turbine system is essentially dependent upon: the length of time of the operation of the turbine; the geographic location of the turbine (wind power available); and how much energy is harvested per unit of time.

Wind Assist W1 thout Sale

For the wind assisted, no sale alternative, the amount of energy saved per $\mathrm{m}^{2}$ per year can be calculated as follows: 


$$
E=\sum_{j=1}^{12} C_{p} \quad P_{j} \quad T_{j} \quad K_{f}
$$

where:

$E=$ amount of the harvested engrgy per unft cross sectional area of the turbine, $\mathrm{kWh} / \mathrm{m}^{2}$ per year.

$C_{p}=$ performance coefficient for the turbine, dimensionless; (1.e., percent of the available power that is converted to shaft power $=0.2$ for this study based on data supplied by the USDA). square meter) for month $j$.

$\mathrm{T}_{\mathrm{j}}=$ monthly hours of operation of the turbine for month $\mathrm{j}$. $\begin{aligned} \mathrm{K}_{\mathrm{f}}= & \text { a conversion factor relating the amount of fuel saved to. } \\ & \text { shaft energy, units of fuel per } \mathrm{kWh} \text {. }\end{aligned}$

fuel $K_{f}$ (unit of fuel/kWh shaft energy)*

$\begin{array}{ll}\text { Diesel } & 0.341 \text { liter } \\ \text { Propane } & 0.5531 \text { lfter } \\ \text { Natural Gas } & 0.427 \mathrm{~m} \\ \text { Electric } & 1.102 \mathrm{kWh}\end{array}$

*Fuel efficiency ( $\mathrm{kWh} / \mathrm{unit}$ of fuel) for Internal combustion engines decreases with decreasing load.

The above values assumed 85 percent of full load for the Internal combustion engines and 90.7 percent average electric motor efficiency.

For the wind assist systems, the wind turbine is assumed to operate simultaneously with the primary power source. Therefore, the turbine would operate for the length of the irrigation pumping season. Representative hours of operation, by month, for the respective wind energy regions were determined from data compiled by James R. Gilley under contract with Southwest Research and Development Company (Gilley, 1980). The data used for computing energy savingo reflect average conditions for the respective regions (Table 1). These monthly distributions were 
estimated by taking monthly hours of operation for each major crop in the region and computing a weighted average based on the proportion of total irrigated acreage devoted to each crop.

\section{Wind Assist With Sale}

For electrical wind-assist systems where surplus energy is sold, the analys1 is slightly different, because the turbine would operate continuously. Some of the generated energy would be used directly in the pumping irrigatton water. The remaining energy would be sold back to the power supplier at a price different from that used to normally pump irrigation water. Therefore, the total energy contribution (ET) was estimated as equation (1) plus the energy sold (ES). Given:

$$
\begin{aligned}
& E S=\sum_{j=1}^{12}\left[C_{p} P_{j}\left(T t_{j}-T_{j}\right) A\right] \\
& \text { where: } \quad E S=\text { electriclty sold, } \mathrm{kWh} / \mathrm{m}^{2} / \text { year. } \\
& \mathrm{Tt}_{j}=\text { total hours in month } \mathrm{j} \text {. } \\
& \text { A = alternator efficiency; assumed to be } 90 \text { percent. } \\
& \text { All other varlables as epecified in equation [3]. } \\
& \text { theil ET }=\sum_{j=1}^{12}\left[C_{p} P_{j} T_{j} K_{I}+C_{p} \dot{P}_{j}\left(I_{j}-T_{j}\right) A\right]
\end{aligned}
$$

Stand Alone System

The energy saved with a stand alone reservoir system (gravity flow) is equal to the total energy requirements of the conventional system:

$$
\begin{aligned}
\mathrm{AF} & =0.00362 \mathrm{~L} \mathrm{~W} \\
\text { where: } & \mathrm{AE} \\
\mathrm{L} & =\text { annual energy saved, } \mathrm{kWh} \\
\mathrm{W} & =\text { volers of head }
\end{aligned}
$$


Table 1. Wind power avallable and hours of turbine operation, by region

\begin{tabular}{|c|c|c|c|c|c|c|c|c|c|c|c|c|c|}
\hline POWER AND TIME & JAN & FEB & MAR & APR & MAY & JUN & JUL & AUG & SEP & OCT & Nov & DEC & ANNUAL \\
\hline & \multicolumn{13}{|c|}{ REGION A } \\
\hline Wind Power $\left(\mathrm{kW} / \mathrm{m}^{2}\right.$; & .378 & .424 & .560 & .544 & .432 & .406 & .296 & .258 & .323 & .319 & .367 & .344 & \\
\hline Hours - Irrigatior: & 0 & 0 & 71 & 96 & 224 & 240 & 370 & 419 & 120 & 65 & 0 & 0 & 1,605 \\
\hline \multirow[t]{2}{*}{ Hours - Non-Irrigation } & 744 & 672 & 673 & 624 & 520 & 480 & 374 & 325 & 600 & 679 & 720 & 744 & 7,155 \\
\hline & \multicolumn{13}{|c|}{ REGION B } \\
\hline Wind Power $\left(\mathrm{kW} / \mathrm{m}^{2}\right)$ & .326 & .311 & .430 & .491 & .381 & .283 & .219 & .219 & .244 & .281 & .370 & .293 & \\
\hline Hours - Irrization & 0 & 0 & 0 & 7 & 48 & 114 & 460 & 460 & 247 & 0 & 0 & 0 & 1,336 \\
\hline \multirow[t]{2}{*}{ Hours - Non-Irriga'1on } & 744 & 672 & 744 & 713 & 606 & 606 & 284 & 284 & 473 & 744 & 720 & 744 & 7,424 \\
\hline & \multicolumn{13}{|c|}{ REGION C } \\
\hline Wind Power $\left(\mathrm{kw} / \mathrm{m}^{2}\right)$ & .178 & .230 & .329 & .319 & .256 & .260 & .154 & .117 & .121 & .131 & .147 & .153 & \\
\hline Hourg - Irrigation & 0 & 0 & 126 & 310 & 71 & 162 & 350 & 415 & 29 & 58 & 0 & 0 & 1,521 \\
\hline \multirow[t]{2}{*}{ Hours - Non-Irrigation } & 744 & 672 & 618 & 410 & 673 & 558 & 394 & 329 & 691 & 686 & 720 & 744 & 7,239 \\
\hline & \multicolumn{13}{|c|}{ REGION D } \\
\hline Wind Power $\left(\mathrm{kW} / \mathrm{m}^{2}\right)$ & .178 & .230 & .329 & .319 & .256 & .260 & .154 & .117 & .121 & .131 & .147 & .153 & \\
\hline Houra - Irrigation & 35 & 98 & 292 & 269 & 279 & 393 & 557 & 522 & 280 & 53 & 91 & 0 & 2,869 \\
\hline \multirow[t]{2}{*}{ Hours - Non-Irrigat Lon } & 709 & 574 & 452 & 151 & 465 & 327 & 187 & 222 & 440 & 691 & 629 & 744 & 5,891 \\
\hline & \multicolumn{13}{|c|}{ REGION E } \\
\hline Wind Power $\left(\mathrm{kV} / \mathrm{m}^{2}\right)$ & .254 & .306 & .337 & .365 & .323 & .297 & .274 & .233 & .196 & .169 & .205 & .212 & \\
\hline Hours - Irrigetion & 0 & 0 & 0 & 161 & 325 & 463 & 443 & 331 & 142 & 11 & 0 & 0 & 1,876 \\
\hline \multirow[t]{2}{*}{ Hours - Non-Irrigation } & 744 & 672 & 744 & 559 & 395 & 257 & 301 & 413 & 578 & 733 & 720 & 744 & 6,884 \\
\hline & \multicolumn{13}{|c|}{ REGION F } \\
\hline Wind Power $\left(\mathrm{kw} / \mathrm{m}^{2}\right)$ & .255 & .299 & .331 & .320 & .187 & .120 & .073 & .070 & .098 & .131 & .260 & .221 & \\
\hline Hours - Irrigation & 0 & 0 & 0 & 0 & 0 & 160 & 240 & 320 & 80 & 0 & 0 & 0 & 800 \\
\hline \multirow{2}{*}{ Hours - Non-Irrigation } & 744 & 672 & 744 & 720 & 744 & 560 & 504 & 424 & 640 & 744 & 720 & 744 & 7,960 \\
\hline & \multicolumn{13}{|c|}{ REGION G } \\
\hline Wind Power $\left(\mathrm{kW} / \mathrm{m}^{2}\right)$ & .088 & $.1: 0$ & .118 & .101 & .064 & .047 & .038 & .034 & .053 & .063 & .069 & .072 & \\
\hline Hours - Irrigation & 0 & 0 & 358 & 358 & 417 & 118 & 151 & 34 & 375 & 353 & 0 & 0 & 2,169 \\
\hline Hours - Non-Irrigation & 744 & $6: 2$ & 386 & 362 & 327 & 602 & 593 & 710 & 345 & 386 & 720 & 744 & 6,591 \\
\hline
\end{tabular}


Reservoir and Turbine Sizing

A stand alone wind system requires a turbine large enough to pump the required water during the course of the year and a reservoix large enough to store the peak monthly difference between inflow and outflow. For any given irrigation situation (water requirements and meters of head), several reservoir-turbine size combinations could be used. As the turbine size increases, the required reservoir size decreases and viceversa. The question becomes: what is the feasible range of turbine and reservoir sizes for use under average conditions in each wind region?

Reservoir size can be determined with an energy balance technique similar to a flood routing procedure. 'l'he linfluw of encrgy, in the form of water, into the reservoir comes from the turbine output. There are two outflows of energy from the reservoir: evaporation losses and irrigation energy water requirements. It was assumed that construction of the reservoir will be such that seepage losses are negligible. The amount of energy stored in the reservoir at anytime is thus the difference between the cumulative inflow and the cumulative outflows. This energy balance relationship can be expressed as:

$$
\begin{aligned}
& \operatorname{EIS}_{n}=\sum_{j=1}^{n} \quad\left[\left(C_{p} P_{j} U T_{j}\right)-\left(\operatorname{EIS}_{\max } 1_{j} / 3.05\right)-\left(\operatorname{IR}_{j} E_{p}\right)\right] \text { [7] } \\
& \text { where: } \text { EIS }_{n}=\text { the amount of energy in storage for month } n \text {, } k W h \\
& \text { EIS }_{\max }=\text { the maximun valie of EIs for the year, kWh } \\
& \mathrm{C}_{\mathrm{p}}=\text { performance coefficient of turbine }(0.2) \\
& \mathrm{P}_{\mathrm{J}} \quad=\text { average monthly wind power available, } \mathrm{kW} / \mathrm{m}^{2} \\
& \mathrm{U} \quad=\text { turbine size, } \mathrm{m}^{2} \\
& \mathrm{~T}_{j} \quad=\text { hours of operation } L_{11} \text { wonth } j \\
& 1_{j}=\text { net evaporalion loso (gross-precipitation) for month } \\
& \mathrm{E}_{\mathrm{p}}=\underset{(0.00362 \mathrm{~L})}{\operatorname{energy}} \text { required to pump one } \mathrm{m} \text { of water, } \mathrm{kWh} / \mathrm{m}^{3} \\
& \begin{aligned}
I R_{j}= & \text { the 1rrigation water requirement of the irrigated } \\
& \text { area for month } \mathrm{j}, \mathrm{m}
\end{aligned} \\
& 3.05=\text { the effective storage depth of the reservoir, } m
\end{aligned}
$$


In the above summations, the months are summed with $j=1$ for the last month of the irrigation season, $j=2$ for the next to last, etc.

The above equation was used to estimate an array of turbine and reservoir size combinations for each region. This involved an iterative process, since the value of EIS $_{\max }$ depends upon the size of the turbine. For a given turbine size, the value of EIS ${ }_{\max }$ was determined subject to these constraints: 1) that the turbine could operate a maximum of 12 months, 2) that all energy was depleted from the reservolr at the end of the irrigation season; and (3) the amount of energy in storage was always enough water to meet crop and evaporative demands once the system was started.

Use of the energy balance equation required developing estimates for the following parameters:

1. pumping lift

2. monthly irrigation water demands

3. monthly gross lake evaporation

4. monthly precipitation

5. monthly wind power available

6. average peak weekly water use rate

7. size of area irrigated per wind system

Estimates of the above parameters were developed for average condttions in each wind region (Appendix A, Tables A-1 to A-7). Pumping lifts, irrigation water demands, peak weekly water use rates and the size of area irrigated per wind system were computed primarily from the results of the irrigation assessment (Gilley, 1980). The monthly precipitation figures used in the analysis were weighted averages (weighted by irrigated area) of the state level data reported in the Climate Atlas (1968). Monthly lake evaporation estimates were developed using the following Blaney Criddle equation:

$$
1_{j}=\left(1.8 T_{j}+32\right) \quad p_{j} / 3937
$$

where: $1_{j}$ = estimated lake evaporation in month $j$, meters

$$
\begin{aligned}
& \mathrm{T}_{\mathbf{j}}=\text { mean monthly air temperature, in degrees Celsius } \\
& \mathrm{P}_{\mathbf{j}}=\text { mean monthly percent of annual daytime hours }
\end{aligned}
$$


In selecting the $T_{j}$ and $p_{j}$ values for each wind region a single location in the center of the irrigated area within the region was used.

The final step in computing turbine versus reservoir size combinations for each region conststed of selecting a finite array of possibilities for each region. This was done by first selecting maximum and minimum feasible reservoir and turbine sizes and then choosing enough points between the two extremes to enable plotting reasonable curves.

It was assumed that a turbine of the maximum size would supply the average peak weekly energy requirement. A turbine of the minimum size would have to operate all year to supply the amount of energy required.

The maximum reservoir size used in the analysis corresponded to the minimum turbine size. It was assumed that the minimum reservoir would have to be large enough to hold at least one day of water use at the average peak weekly use rate for the area irrigated.

The resulting reservoir versus turbine size combination for the seven regions are shown in Appendix $A$ in both tabular (Tables A-1 to A-7) and graphic form (Figures $A-1$ to $A-7$ ). The range of turbine sizes goes well beyond what is feasible mechanically. "Impossible" turbine sizes were Included so that a complete range of economic tradeoffs between reservoir costs and turbine size could be shown for each region.

\section{Economic Analysis}

The acquisition of a wind turbine involves making a substantial initial investment that will produce benefits over a long period of time (20 years). Thus, the timing of the cost and returns must be considered in the economic analysis. The discounted cash flow technique was used in the study, as it enables all the future cash f́lows to be discounted to the present values by use of an interest rate that may approximate the irrigator's cost of capital. The present value computations represent the amount an,irrigator can pay based on that stream of anticipated future annual returns. 
Three energy price scenarios for each fuel source were used in the analysis. Specification of these price scenarios involved first determining an average current price for each fuel source in each region. The initial prices were then increased at varying rates over time to reflect possible future conditions.

Average base prices for diesel, gasoline, and liquid petroleum gas (LPG) for each region were estimated from USDA data by weighting the average price for each state by region by the proportion of total regional irrigated areas in that state (Table 2). The base price data for natural gas were obtained, by region, for late 1979 and early 1980, from. the American Gas Association Rate Services and were adjusted to January, 1980 prices. The base price data for electricity, by region, were obtained by telephone interviews with relevant state agencies in the study regions (Table 2). The value of surplus electricity produced to be sold to local utilities was estimated by USDA and USDOE personnel to be 60 percent

Table 2. Energy price, by source and region, January 1980

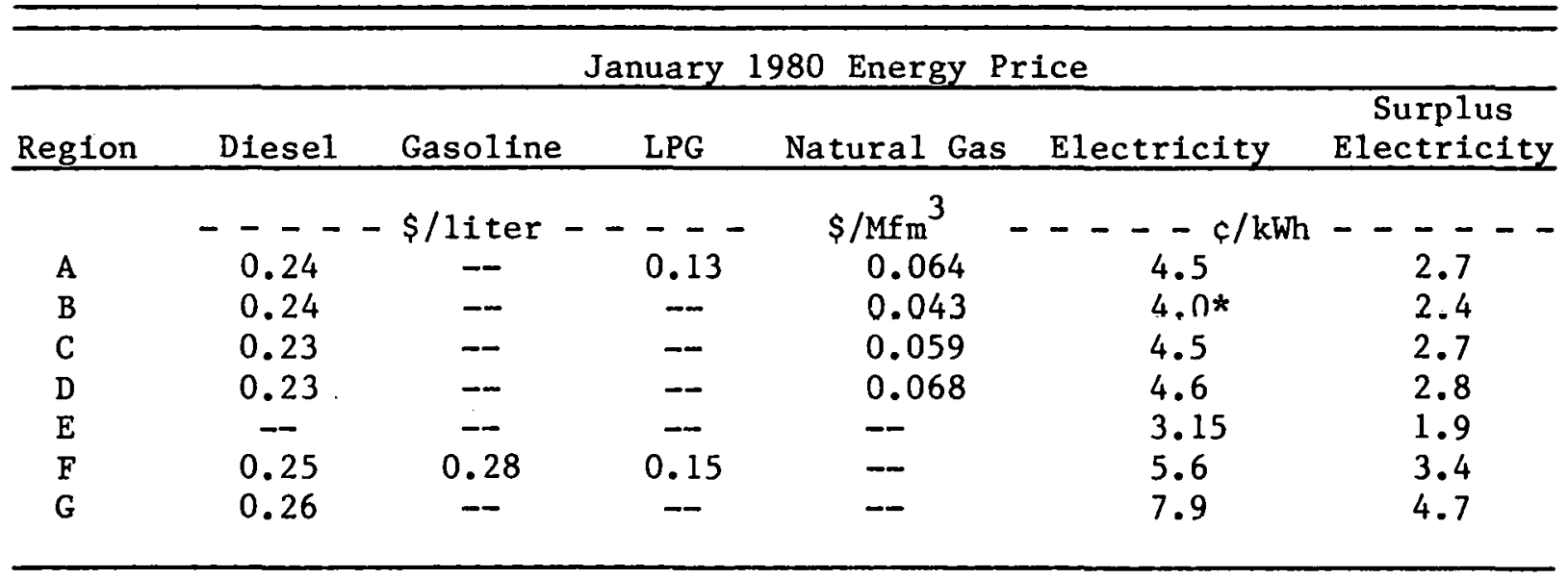

* Plus $\$ 17.43$ per Installed kilowatt capacity of the electric motor. of the price irrigators pay for electricity for irrigation pumping. This value is higher than the typically quoted 40 to 50 percent of electricity purchases. However, it was assumed that some of the surplus electricity 
would be used by the farmer for other farm uses, thus increasing the blend value to about 60 percent of the retail price.

The three 20-year price scenarios (high, medium, and low) were developed in consultation with the personnel from USDA and USDOE.

The high energy price scenario is the maximum expected energy price increases in real terms over the next 20 years. The high energy price scenario projections were:

Fossil Fuels: January, 1980 energy prices are compounded at a rate of 35 percent per year for two years and then at a rate of 8 percent per year thereafter.

Electricity: January, 1980 electricity rate price is compounded at a rate of 20 percent per year for two years and then at 4 percent per year thereafter.

The low energy price scenario is the minimum real energy price in-creases that could be expected for the next 20 years. The energy price projections for this alternative are as follows:

Fossil Fuel: Prices were increased at an annual compounded rate of 4 percent per year for the entire 20-year period.

Electricity: Prices were increased at an annual compounded rate of 2 percent per year for the entire 20-year perlod.

A medium energy price ecenario was developed for sensitivity analysis. The energy projections tor this scenario were:

Fossil fuel: Prices were increased at an annual compounded rate of 8 percent per year for the entire 20 -year period.

Electricity: Prices were increased at an annual compounded rate of 4 percent per year for the 20 -year period.

Breakeven Investment Values for Wind-Assist Systems

The central economic question to be analyzed is, How much can irrigators in each situation (wind region and fuel source) afford to pay for wind machines of different sizes? An answer to this question can be conceptualized as follows for all wind assist, including sale of or no sale of surplus electricity. 


$$
v_{i}=\sum_{t=1}^{20} \frac{E_{i} P e_{i t}+E S_{i} P_{i t}-M}{(1+r)^{t}}
$$

where: $v_{i}=$ investment value in dollars per square meter of turbine for case $i$, before taxes.

$t=$ time in years (20 years for system life was assumed based on consultation with personnel from USDA)

$E_{i}=$ units of energy saved in case $i$ (from Eq. 3)

$\mathrm{Pe}_{\text {it }}=\begin{gathered}\text { energy price for case } i \text { in year } t \text { (price of energy } \\ \text { saved) }\end{gathered}$

$\mathrm{ES}_{i}=$ units of energy sold in case $i$ (from Eq. 4)

Pes $_{i t}=\begin{aligned} & \text { energy price for case } i \text { in year } t \text { (price of energy } \\ & \text { sold) }\end{aligned}$

$M \quad=$ operation and maintenance charge $\left(\$ 10 / \mathrm{m}^{2}\right)$. This figure is a preliminary judgement of officials from USDA who have experience with experimental turbines)

$r \quad=$ discount $\operatorname{rate}(7$ and 10 percent)

\section{Breakeven Investment Values for Stand Alone Systems}

Analysis of the stand alone-reservoir system is more complicated than the wind assist system. With this system, the amount that irrigators could pay for a wind turbine equals the present value of the fossil fuel savings, plus the present value of the savings from displacing a conventional power unit, minus reservoir costs. For any given reservoir size and set of wind region parameters $(k)$, the investment value of the corresponding turbine size (U) can be expressed as:

$$
I_{u k}=\sum_{j=1}^{n} \frac{F S P e_{i}+C-M U-R}{(1+r)^{n}}
$$


where: $\mathrm{I}_{\mathrm{uk}}=$ investment value of turbine size $\mathrm{U}$ in wind region $k$ in 1980 dollars

$$
\begin{aligned}
& \text { FS = units of fuel saved } \\
& \mathrm{Pe}_{i}=\text { price of fuel per unit in year } i \\
& \text { C = annual savings from avoiding the cost of a } \\
& \text { conventional power plant } \\
& M=\text { annual maintenance charge } / \mathrm{m}^{2} \text {, assumed to be } \$ 10 / \mathrm{m}^{2} \\
& \mathrm{U}=\text { turbine size in } \mathrm{m}^{2} \\
& \mathrm{R} \quad=\text { reservoir construction costs } \\
& \text { n = assumed 20-year project 11fe }
\end{aligned}
$$

Estimates of fuel saved (FS) were based on the energy required to lift the average water requirement in each region a given average lift (see Appendix A, Tables A-1 to A-7).

The annual savings due to replacement of a conventional power plant (C) were equal to the amortized investment cost at 10 percent interest, plus a 5 percent operation and maintenance allowance. The investment costs used for each engine size were from data compiled by Extension economists at the University of Nebraska-Lincoln in early 1980.

Reservoir construction costs $(R)$ were estimated by computing the amount of rolled fill material required and the surface area that would be lined for each reservoir size, and multiplying times $\$ 1.08$ per cubic meter for the fill material and $\$ 1,215$ per hectare for lining. It was assumed that each side of a square reservoir would be 2.4 meters wide on top, 3.05 meters high and 14.6 meters wide at the bottom. The unit costs used were expected averages, based on the recent experience of the Soil Conservation Service; USDA.

Project life was assumed to be 20 years for both the wind turbine and the reservoit.

\section{Effect of Taxes on Investment Values}

Federal income tax provisions strongly affect the economic feasibility of an investment such as a wind turbine. Tax savings generated by 
the investment can be added to the savings from reduced fuel requirements and revenues from possible surplus power sales. Adding the tax savings increases the amount that an irrigator can afford to pay for a wind turbine. The magnitude of this increase depends on the irrigator's marginal tax bracket. The irrigators in the highest tax bracket could justify the highest investment in wind turbines.

Because of the widely varying income positions of irrigators in each region, it is not possible to select a single set of parameters as typical after tax conditions. Thus, for purposes of this study, a set of adjustment factors was computed for a variety of tax situations (table 3 ). These adjustment factors, when multiplied by the results of equations 9 and 10, indicated what producers in the various tax and irrigation situations could afford to pay for wind turbines.

Six different federal tax situations were considered at two different depreciable lives, 10-year and 20-year (see table 3 for a list). The results indicate that tax considerations increase investment values by as much as 108 percent for someone in the 5.0 percent tax bracket who takes all credits he is entitled to and uses a 10-year depreciation schedule, plus 20-percent additional first-year depreciation. Probably more typical would be an investor in the 25-percent tax bracket with enough income to take all credits he is entitled to, who elects to use a 10-year depreciation schedule with 20-percent additional first-year depreciation. Someone in this circumstance could afford to pay about 54 percent more than the estimated beforetax values for a wind turbine.

\section{Typical Sizc and Cost of Wind Turbines}

Typical turbine size for irrigation is expected to range from 75 to 300 square meters. Table 4 presents conversions from size of turbines in square meters to diameter in meters, and power level at a wind speed of 10 meters per second in kilowatts. For example, a $200 \mathrm{~m}^{2}$ turbine is 15.96 moters in diameter and would be rated at 24 kllowatts.

The only information currently available on the cost of wind turbines is that associated with experimental units. Such units currently cost approxiluately $\$ 250$ per square meter of turbine area for a commercial sized unit. The total investment an irrigator would have to make, however, is 
Table 3. Adjustment factors for converting before-tax investment values to after-tax values at different tax rates and depreciation schedules*

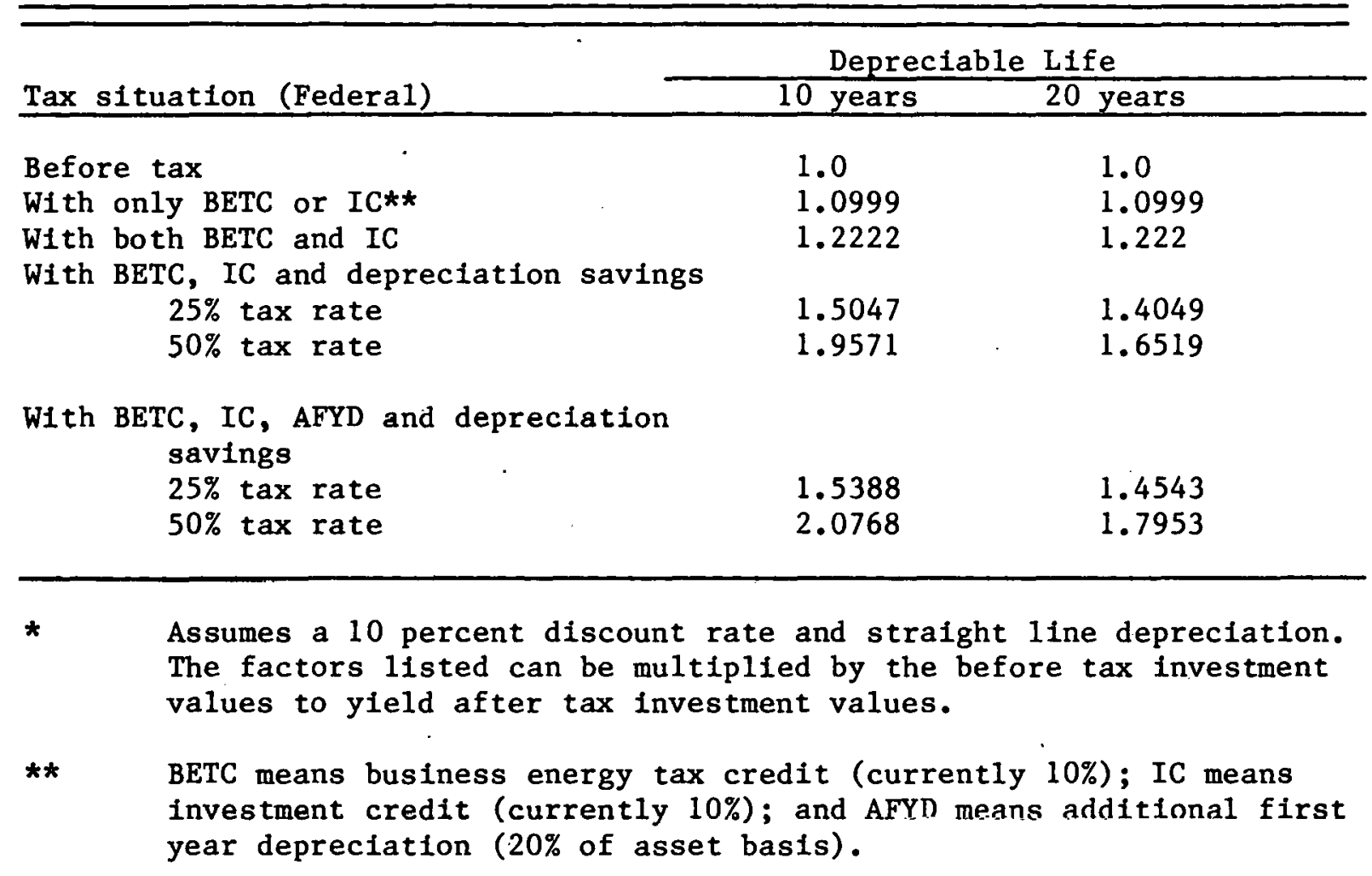

Table 4. Conversion sizes of turbines (square meters) to diameter (meters) to power level at a wind speed of 10 meters per second

\begin{tabular}{ccc}
\hline & & $\begin{array}{c}\text { Power Level at a Wind Speed } \\
\text { of } 10 \mathrm{~m} / \text { second }\end{array}$ \\
\hline & Diameter of Turbine & (kilowatts) \\
$\left(\mathrm{m}^{2}\right)$ & $-(\mathrm{m})$ & 3 \\
25 & 5.64 & 6 \\
50 & 7.98 & 9 \\
75 & 9.77 & 12 \\
100 & 11.28 & 15 \\
125 & 12.62 & 18 \\
150 & 13.82 & 21 \\
175 & 14.93 & 24 \\
200 & 15.96 & 36 \\
300 & 19.54 & 48 \\
400 & 22.57 & 60 \\
500 & 25.23 & 120 \\
1,000 & 35.68 & \\
\hline
\end{tabular}


- dependent on the size required for his particular situation. The typical irrigation systems would probably require a unit $75 \mathrm{~m}^{2}(9 \mathrm{~kW})$ in size to $300 \mathrm{~m}^{2}(36 \mathrm{~kW})$, depending on energy requirements and available wind power. Thus, the total investment for a typical wind assist system is probably in the $\$ 18,750-\$ 75,000$ range, by current prices. When, and if, wind turbines become avallable in commercial quantities, these costs will likely decrease significantly.

The total investment for stand alone systems would be much higher because of larger turbine requirements and reservoir construction costs. 


\section{THIS PAGE \\ WAS INTENTIONALLY \\ LEFT BLANK}


The results will be presented first for energy saved by wind-powered turbines for irrigation pumping, followed by the amount of surplus electricity available for sale. Then, an economic analysis will be presented by type of wind-powered irrigation system - wind assist without sale of surplus energy, wind assist with sale of surplus electricity and stand alone reservoir system with gravity flow from reservoir. In addition, the effect of federal taxes and incentives on investment values will be discussed.

\section{Amount of Energy Saved}

The estimated amount of energy saved per square meter of turbine size from assisting conventionally powered irrigation pumping units with wind turbines ranged from $13 \mathrm{kWh} / \mathrm{m}^{2}$ per year in Region $\mathrm{F}$ to $117 \mathrm{kWh} / \mathrm{m}^{2}$ in Region D (Figure 7). It was $113 \mathrm{kWh} / \mathrm{m}^{2}$ in Region A, 77 in Region B, 57 in Region C, 106 in Region $E$, and $32 \mathrm{kWh} / \mathrm{m}^{2}$ in Region G.

\section{Amount of Surplus Electricity Available for Sale}

The amount of electricity available for sale or use on the farm from the wind turbine when irrigation pumping is not required ranged from 565 $\mathrm{kWh} / \mathrm{m}^{2}$ for Region A to $93 \mathrm{kWh} / \mathrm{m}^{2}$ for Region $\mathrm{G}$ (Figure 7). It was 488 $\mathrm{kWh} / \mathrm{m}^{2}$ for Region B, 291 for Region C, 232 for Region D, 356 for Region $E$, and $331 \mathrm{kWh} / \mathrm{m}^{2}$ for Region $\mathrm{F}$.

\section{Breakeven Investmenı Values}

The amount one could invest in wind turbines was estimated for average conditions - monthly average wind power, average performance of wind turbines, and average base prices for conventional energy.

\section{Wind Assist Without Sale of Surplus Electricity}

Under this alternative, in the before-federal-tax investnent per square meter of turbine to replace conventional fuels, 


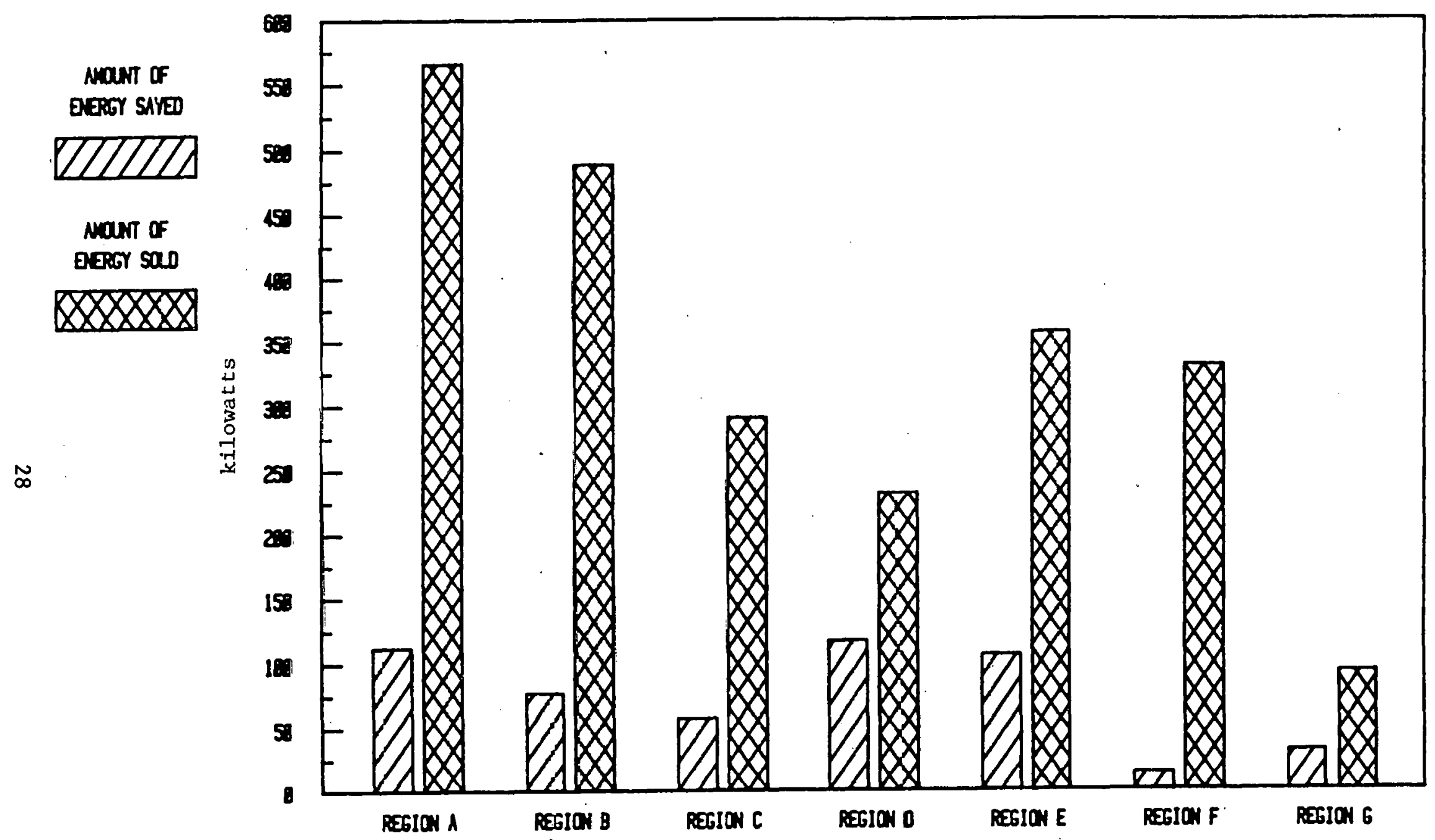

Figure 7. The potential amount of energy saved from using wind turbines for pumping irrigation and the amount of surplus electricity available for sale from the use of wind turbines by region. 
Table 5. Investment Value Per Square Meter for Wind Assist Turbines by Energy Source and Energy Price Scenario; by Region.

\begin{tabular}{|c|c|c|c|c|c|c|c|c|c|c|c|c|c|c|c|c|}
\hline \multirow{3}{*}{$\begin{array}{c}\text { Wind } \\
\text { Region }\end{array}$} & \multirow[b]{2}{*}{ Discount } & \multicolumn{3}{|c|}{ Diesel } & \multicolumn{3}{|c|}{ Gasoline } & \multicolumn{3}{|c|}{ LPG } & \multicolumn{3}{|c|}{ Natural Gas } & \multicolumn{3}{|c|}{ Electricity } \\
\hline & & $\mathrm{H}$ & $M$ & $\bar{L}$ & $\mathrm{H}$ & $M$ & L & $\mathrm{H}$ & $\mathrm{M}$ & $\mathrm{L}$ & $\mathrm{H}$ & $M$ & $\mathrm{~L}$ & $\mathrm{H}$ & $\mathrm{M}$ & $\mathrm{L}$ \\
\hline & (percent) & --- & -- & --1 & - & -- & $-d o l$ & Iss per & squar & meter & --- & -- & -- & - & -- & -- \\
\hline \multirow[t]{2}{*}{ A } & 10 & 132 & 59 & 20 & -- & -- & - & 106 & 42 & 8 & 4 & -26 & -42 & -10 & -25 & -33 \\
\hline & 7 & 186 & 86 & 29 & - & -- & - & 151 & 63 & 14 & 13 & -28 & -51 & -8 & -29 & -40 \\
\hline \multirow[t]{2}{*}{ B } & 10 & 61 & 12 & -14 & - & - & - & -- & -- & - & -44 & -58 & -65 & -37 & -46 & -51 \\
\hline & 7 & 91 & 23 & -15 & - & - & -- & -- & - & - & -51 & -70 & -80 & -44 & -56 & -63 \\
\hline \multirow[t]{2}{*}{ C } & 10 & -44 & -58 & -65 & -- & - & - & - & - & - & -44 & -58 & -65 & -44 & -50 & -55 \\
\hline & 7 & -51 & -70 & -80 & -- & - & - & -- & - & -- & -51 & -70 & -80 & -53 & -64 & -69 \\
\hline \multirow[t]{2}{*}{ D } & 10 & - & -- & - & -- & -- & -- & -- & - & - & 13 & -20 & -38 & -5 & -22 & -30 \\
\hline & 7 & - & -- & -- & - & - & - & -- & - & - & 25 & -20 & -45 & -3 & -25 & -36 \\
\hline \multirow[t]{2}{*}{$E$} & 10 & - & -- & - & - & - & -- & - & - & - & - & - & - & -34 & -44 & -48 \\
\hline & 7 & -- & -- & -- & - & - & - & - & -- & - & - & - & - & -39 & -53 & -60 \\
\hline \multirow[t]{2}{*}{ F } & 10 & -59 & -68 & -73 & -44 & -58 & -65 & -60 & -68 & -73 & - & - & - & -69 & -71 & -72 \\
\hline & 7 & -71 & -83 & -89 & -50 & -69 & -79 & -72 & -84 & -90 & - & -- & - & -85 & -88 & -90 \\
\hline \multirow[t]{2}{*}{ G } & 10 & -20 & -42 & -53 & -- & -- & -- & -- & -- & - & - & - & -- & -44 & -52 & -55 \\
\hline & 7 & -18 & -48 & -65 & -- & -- & - & -- & -- & - & - & - & - & -54 & -64 & -69 \\
\hline
\end{tabular}

* $\mathrm{H}=$ higher price scenario, where January 1980 energy source price for fossil fuels are compoumded at a rate. of.. 35 percent for two years and then 8 percent per year for 18 years. For electricity the price is campounded at 20 percent per year for two years and then 4 percent per year for 18 years.

$M=$ medium price scenario, where January 1980 fossil fuel price is 8 percent per year for 20 years and electricity price is compounded at a rate of 4 percent per year for 20 years.

$L=$ low price scenario, where January 1980 fośsil fuel price is compounded at a rate of 4 percent per year for 20 years and electricity price is compounded at a rate of 2 percent per year for 20 years. 
under the high energy price scenario for diesel, with a 10 percent discount rate, ranged from $\$ 132 / \mathrm{m}^{2}$ in the windiest region, the Southern $\mathrm{HIgh}$ Plains (Region A), to a negative $(-) \$ 59 / \mathrm{m}^{2}$ for the Midwest (Region F); for LPG, from $\$ 106 / \mathrm{m}^{2}$ in Region $A$ to $(-) \$ 60 / \mathrm{m}^{2}$ in Region $F$; for natural gas, from $\$ 13 / \mathrm{m}^{2}$ in Southern Arizona and Southern California (Region $D$ ) to $(-) \$ 44 / \mathrm{m}^{2}$ in the Northern High Plains and Edwards Plateau of Texas and the Pecos River Basin of New Mexico (Regions $B$ and $C$ ); and for electricity, from (-) $\$ 5 / \mathrm{m}^{2}$ in Region $D$ to $(-) \$ 69 / \mathrm{m}^{2}$ in Region $F$ (Table 5). Under the medium price scenario, however, the investment values dropped to less than 50 percent of the values undr the high price scenario for most fuels, and were even lower under the low energy price scenario. Under the high energy price scenario, at a discount rate of 7 percent, investment values for diesel ranged from $\$ 186 / \mathrm{m}^{2}$ in Region A to (-) 79 in Region F; for LPG, from $\$ 151 / \mathrm{m}^{2}$ in Region A to (-) $79 / \mathrm{m}^{2}$ in Region F; for natural gas, from $\$ 25 / \mathrm{m}^{2}$ in Region $D$ to $(-) \$ 51 / \mathrm{m}^{2}$ in Regions $B$ and $C$; and for electricity, from $(-) \$ 3 / \mathrm{m}^{2}$ in Region $D$ to $(-) \$ 85 / \mathrm{m}^{2}$ in Region $F$. The investment values were lower under the medium and low energy price scenarios. The negative investment values indicate that the discounted fuel savings would not cover the discounted operation and operation costs of $\$ 10 / \mathrm{m}^{2}$.

When tax savings are considered, a diesel using irrigator in the high wind power regton (Region $A$ ), who is in a 25 percent federal tax brackel, and only claims business energy tax credit and inveftmont credit could afford to invest $\$ 161 / \mathrm{m}^{2}$ instead of the before tax savings of $\$ 132 / \mathrm{m}^{2}$. If the additional first-year depreciation and annual depreciation were included, the investment for wind turbines would increase to $\$ 192 / \mathrm{m}^{2}$.

LFG users in the same tax situation could afford to invest $\$ 106 / \mathrm{m}^{2}$ in the before-tax case, or $\$ 154$ when all tax credits are clalmed. Investment values for all nther wind aosist situallons were much lower (ail less than $\$ 75 / \mathrm{m}^{2}$ ) at the medium energy price scenar10. These systems would not be cconomically attractive unless production costs could be reduced well below the current cost of about $\$ 250 / \mathrm{m}^{2}$ for prututype units, even including federal tax considerations. 
The best opportunities appear to be to replace diesel and LPG in the Southern High Plains (Region $A$ ) and diesel in the Northern High Plains (Region B). Replacing conventional sources of energy with wind power does not appear to be a viable alternative in any of the other regions.

Replacing gasoline or electricity do not appear to be viable alternatives in any region or scenario. Gasoline is used in any large quantities only in the Midwest, where irrigation is supplemental, and is used only for short periods in the irrigation season. Electricity is a relatively cheap bource of energy for most areas under investigation. The most negative investment values of wind turbines were found for replacing electricity in the two supplemental irrigated areas (South and Midwest), closely followed by Region $C$.

Figures B-1 through B-5 in Appendix B present the investment that irrigators could afford to make, by turbine size, energy price scenario, and region. The figures were prepared only for the alternatives in which the discounted investment values were positive (Table 5). For example, an irrigator requiring an 18 kilowatt wind turbine (the turbine size conversion from square meters to kilowatts in Table 4 shows this to be $150 \mathrm{~m}^{2}$ ), could afford to invest $\$ 19,800$, without federal tax considerations, for a $150 \mathrm{~m}^{2}$ wind turbine in Region A to replace a diesel powered pumping unit, under the high energy price scenario, with a 10 percent discount rate; $\$ \mathbf{8 , 8 5 0}$ under the medium energy price scenario; and only $\$ 3,000$ under the low energy price scenario (Figure B-1). Similar maximum investment values can be obtained from Figures B-2 through B-5 for the various regions, energy types, and energy price scenarios.

\section{Wind Assist With Sale of Surplus Electricity}

Wind assist with sale of surplus electricity is more attractive economically than wind assist alone (Table 6). Under this alternative, the investment per squarc meter for a wind turbine under the high energy price scenario, with a 10 percent discount rate, ranged from $\$ 217 / \mathrm{m}^{2}$ in Region A to $\$ 21 / \mathrm{m}^{2}$ in Region G (Table 6). It was $\$ 137 / \mathrm{m}^{2}$ in Region $B$, $\$ 73 / \mathrm{m}^{2}$ in Region C, $\$ 89 / \mathrm{m}^{2}$ in Region D, $\$ 66 / \mathrm{m}^{2}$ in Region $E$, and $\$ 97 / \mathrm{m}^{2}$ in Region F. 
Table 6.' Investment Values Per Square Meter for Wind Assist Turbines

Selling Surplus Electricty by Energy Price Scenario and Region

\begin{tabular}{|c|c|c|c|c|}
\hline \multirow{2}{*}{$\begin{array}{c}\text { Wind } \\
\text { Region }\end{array}$} & \multirow{2}{*}{$\begin{array}{c}\text { Discount } \\
\text { Rate }\end{array}$} & \multicolumn{3}{|c|}{ Energy Price Scenario } \\
\hline & & High & Medium & Low \\
\hline & (percent) & -- & is per s & eter - - \\
\hline A & $\begin{array}{r}10 \\
7\end{array}$ & $\begin{array}{l}217 \\
285\end{array}$ & $\begin{array}{l}146 \\
192\end{array}$ & $\begin{array}{l}115 \\
148\end{array}$ \\
\hline B & $\begin{array}{r}10 \\
7\end{array}$ & $\begin{array}{l}137 \\
181\end{array}$ & $\begin{array}{r}85 \\
113\end{array}$ & $\begin{array}{l}63 \\
81\end{array}$ \\
\hline $\mathrm{C}$ & $\begin{array}{r}10 \\
7\end{array}$ & $\begin{array}{l}73 \\
98\end{array}$ & $\begin{array}{l}38 \\
50\end{array}$ & $\begin{array}{l}22 \\
28\end{array}$ \\
\hline $\mathrm{D}$ & $\begin{array}{r}10 \\
7\end{array}$ & $\begin{array}{r}89 \\
120\end{array}$ & $\begin{array}{l}50 \\
68\end{array}$ & $\begin{array}{l}32 \\
43\end{array}$ \\
\hline $\mathrm{E}$ & $\begin{array}{r}10 \\
7\end{array}$ & $\begin{array}{l}66 \\
90\end{array}$ & $\begin{array}{l}32 \\
42\end{array}$ & $\begin{array}{l}18 \\
23\end{array}$ \\
\hline $\mathbf{F}$ & $\begin{array}{r}10 \\
7\end{array}$ & $\begin{array}{r}97 \\
128\end{array}$ & $\begin{array}{l}54 \\
73\end{array}$ & $\begin{array}{l}36 \\
47\end{array}$ \\
\hline G & $\begin{array}{r}10 \\
7\end{array}$ & $\begin{array}{l}21 \\
30\end{array}$ & $\begin{array}{r}-2 \\
0\end{array}$ & $\begin{array}{l}-7 \\
-5\end{array}$ \\
\hline
\end{tabular}

When all tax credits (BETC, IC, AFYD, and depreclatinn) were clalmcd, the maximum investment per square meter for wind turbiues rangèd frrom $\$ 315$ in Region $A$ to $\$ 31$ in Region $G$ for an irrigator in the 25 percent federal income tax bracket. Under the medium price scenario, the Investment ranged from (-) $\$ 2 / \mathrm{m}^{2}$ in Region $G$ to $\$ 146 / \mathrm{m}^{2}$ in Region A without federal tax and investment credits, and from $\$ 1 / \mathrm{m}^{2}$ in Region $\mathrm{G}$ to $\$ 212 / \mathrm{m}^{2}$ In Region A with federal tax credits.

Investment values appear to he high enough in Region $A$ under both the high and medium energy price scenarios to merit serious considerations. Under the high energy price scenario, in Region $B$, wind turbines almost merit consideration if the irrigator is under the 25 percent federal tax bracket, and they merit consideration for irrigators under the 50 percent federal income tax bracket. It appears that no other region merits serious consideration at this time. 
The investment values under the high energy price scenario without federal tax and incentive considerations, were even higher when a 7 percent discount rate was used, ranging from $\$ 285 / \mathrm{m}^{2}$ in Regton A to $\$ 30 / \mathrm{m}^{2}$ in Region G (Table 6).

Figures C-1 through C-7 in Appendix C present the investment values that farmers could afford in wind turbines, by turbine size, energy price scenario, discount rate, and wind region. For example, an Irrigator could afford to pay $\$ 32,550$ for a $150 \mathrm{~m}^{2}(18 \mathrm{kWh})$ wind turbine in Region A to réplace á conventional energy powered pumping unit, under the high energy price scenario (Figure $\mathrm{C}-1$ ). Simflar maximum investment values can be obtained from Figures $\mathrm{C}-2$ through $\mathrm{C}-7$ for the various regions and energy price scenarios.

\section{Stand Alone System}

The amount one could afford to invest in wind turbines for a stand alone system was estimated for average conditions in each region, under three energy price scenarios for each major energy source. If the high energy price scenario is expected, the maximum before-tax investment value per square meter and the corresponding wind turbine sizes to replace the energy source in each region are: Region $A$, diesel, $\$ 702 / \mathrm{m}^{2}$, $197.2 \mathrm{~m}^{2}$; Region $B$, diesel, $\$ 178 / \mathrm{m}^{2}, 326.3 \mathrm{~m}^{2}$; Region $\mathrm{C}$, natural gas, $\$ 45 / \mathrm{m}^{2}, 694.5 \mathrm{~m}^{2}$ Region D, electricity, $\$ 129 / \mathrm{m}^{2}, 830.7 \mathrm{~m}^{2}$; Region $\mathrm{E}$, electricity, $\$ 78 / \mathrm{m}^{2}, 628.0 \mathrm{~m}^{2}$; Region F, gasoline, $\$ 91 / \mathrm{m}^{2}, 354.5 \mathrm{~m}^{2}$; and Region G, diesel, $\$ 143 / \mathrm{m}^{2}, 416.5 \mathrm{~m}^{2}$ (Table 7).

The maximum value of wind turbines is much lower in most regions, if one interprets the data more conservatively. Assuming that the maximum turbine size that is feasible in either a physical or an economic sense is about $250 \mathrm{~m}^{2}$, and further assuming that all liquid fuels are avaflable to each irrigator, the maximum values for Regions A through $G$, at the high energy price scenario, without federal tax considerations, and at 10 percent interest, are $\$ 573, \$ 150, \$ 0, \$ 0, \$ 75$, and $\$ 0$ per square meter, respectively, and $\$ 805, \$ 230, \$ 2, \$ 0, \$ 0, \$ 115$, and $\$ 0$ per square meter, respectively, when all tax credits are claimed by an irrigator in the 25 percent federal income tax bracket. Under the medium price scenario rates, the highest values, by region, are $\$ 344, \$ 51, \$ 0, \$ 0, \$ 0, \$ 7$, and 


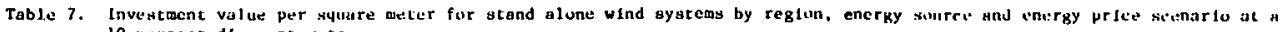
10 percent discuunt rate

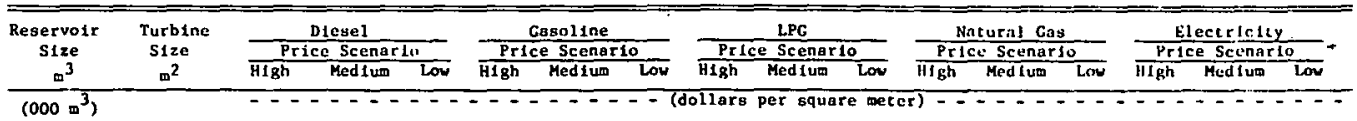

WIND REGION A

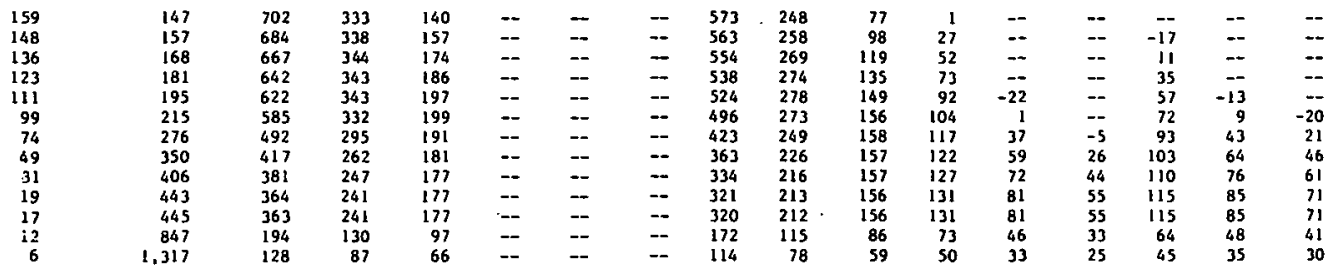

WIND RECION B

\begin{tabular}{|c|c|c|c|c|c|c|c|c|c|c|c|c|c|c|c|c|}
\hline 140 & 93 & -35 & $-\infty$ & -- & -- & -- & -- & -- & -- & -- & -- & - & -- & $\ldots$ & - & -- \\
\hline 148 & 122 & 45 & -- & -- & -- & $=-$ & $\therefore$ & -- & -- & -- & -- & -- & - & - & -- & -- \\
\hline 123 & 152 & סל & -50 & - & - & - & - & -- & -- & -- & -- & -- & - & -. & -- & -- \\
\hline 74 & 224 & iso & 51 & -1 & - & -- & -- & -- & -- & -- & -- & - & -- & -- & -- & -. \\
\hline 49 & 271 & 163 & 81 & 38 & -- & -- & -- & - & -- & -- & -36 & -- & $\rightarrow$ & -1 & -25 & -36 \\
\hline 20 & 326 & 178 & 110 & 75 & - & - & -- & -- & -- & -- & 13 & -6 & $=-$ & 42 & 22 & 13 \\
\hline 12 & 462 & 136 & 88 & 63 & - & -- & -- & $\cdots$ & -- & -- & 19 & 6 & -2 & 40 & 26 & 19 \\
\hline 6 & 567 & 118 & 79 & 59 & -- & -- & -- & -- & -. & -- & 23 & 12 & 6 & 40 & 29 & 23 \\
\hline 5 & 592 & 115 & 78 & 58 & -- & -- & -- & -- & -- & -0 & 24 & 14 & 8 & 40 & 29 & 24 \\
\hline
\end{tabular}

WIND RECION C

\begin{tabular}{|c|c|c|c|c|c|c|c|c|c|c|c|c|c|c|c|c|}
\hline 80 & 2,37 & - & - & -- & -- & - & -- & -- & -- & -- & -7 & -- & -- & -10 & -- & -- \\
\hline 74 & 257 & -- & -- & -- & - & - & -- & - & $-m$ & $=-$ & 4 & -- & -- & 0 & -- & -- \\
\hline 62 & 32.3 & -- & -- & -- & -- & -- & -- & -- & -- & -- & 19 & -21 & - & 16 & -1 & -11 \\
\hline 63 & 455 & -- & -- & -- & - & -- & - & -- & -- & - & 31 & 3 & -- & 29 & 10 & 2 \\
\hline 31 & 344 & -- & -- & -- & -- & -- & -- & -- & -- & -- & 37 & 13 & $\therefore$ & 35 & 19 & 12 \\
\hline 19 & 633 & $=$ & -- & -- & -- & -- & -- & -- & -- & - & 42 & 21 & 10 & 40 & 27 & 21 \\
\hline 12 & 678 & -- & $\cdot-$ & -- & -- & - & -- & - & -- & -- & 44 & 25 & 15 & 43 & 30 & 25 \\
\hline 10 & 694 & -- & -- & -- & - & - & - & $m$ & - & -- & 45 & 27 & 17 & 44 & 32 & 26 \\
\hline 6 & 1.557 & - & -- & -- & -- & -- & - & -- & -- & - & 22 & 14 & 9 & 22 & 16 & 13 \\
\hline 4 & 2,020 & - & -- & -- & -- & -- & -- & -- & -- & - & 18 & 11 & 8 & 17 & 13 & 11 \\
\hline
\end{tabular}

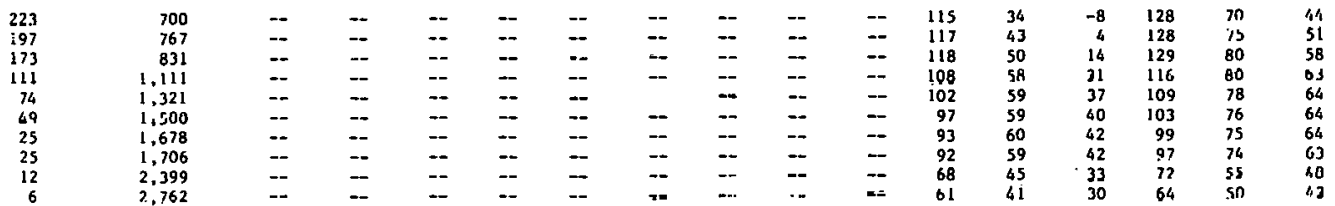

WIRD REGION $\mathbf{E}$

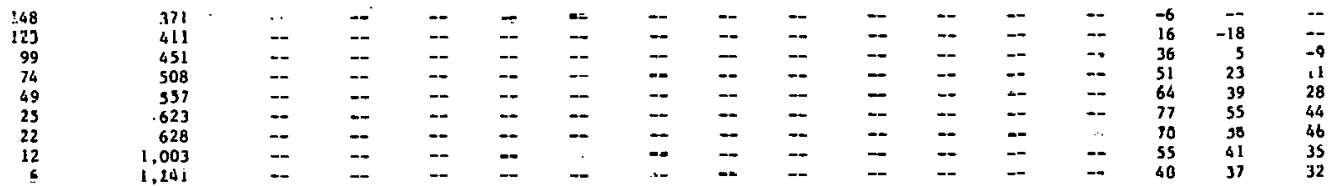

UTND REGION $\boldsymbol{P}$

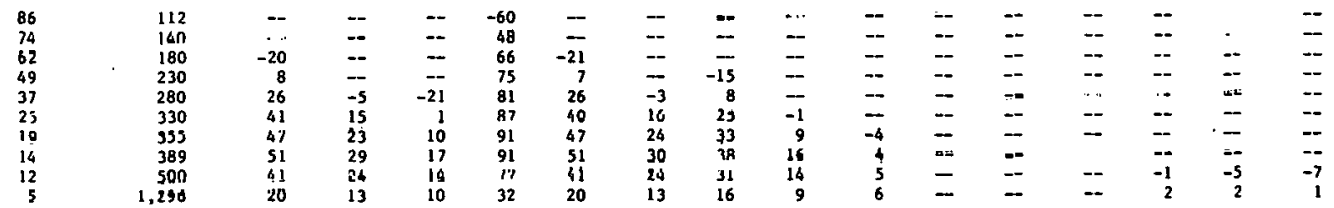

WIND RECION G

\begin{tabular}{|c|c|c|c|c|c|c|c|c|c|c|c|c|c|c|c|c|}
\hline 06 & 300 & 119 & 36 & -7 & -- & -- & - & -- & -- & - & $\therefore$ & -- & - & -1 & $\cdots$ & +- \\
\hline 80 & 312 & 122 & 43 & 2 & - & $m$ & $\infty$ & - & -- & -- & - & -- & - & 7 & 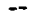 & -- \\
\hline 74 & 323 & 125 & 49 & 9 & -- & - & - & - & -- & -- & -- & - & - & 14 & - & -- \\
\hline 62 & 352 & 129 & 60 & 23 & - & -- & -- & -- & -- & - & -- & -- & $=$ & 27 & -3 & - \\
\hline 49 & 382 & 133 & 69 & 35 & -- & -- & -- & - & $=$ & -- & - & -- & -- & 39 & 9 & -2 \\
\hline 37 & 411 & 163 & 88 & 53 & -- & -- & -- & - & - & - & - & - & - & 57 & 29 & 19 \\
\hline 25 & 502 & 124 & 76 & so & - & - & -- & - & - & - & - & -- & -- & 53 & 30 & 22 \\
\hline 12 & 604 & 115 & 74 & 53 & - & -- & - & - & -- & - & - & -- & - & 56 & 37 & 30 \\
\hline 11 & 614 & 116 & 74 & 54 & -- & $=-$ & - & - & -- & - & -- & - & $\cdots$ & 56 & 38 & 30 \\
\hline 6 & 1,530 & 48 & 32 & 26 & -- & - & - & -- & -- & - & -- & -- & -- & 25 & 17 & 14 \\
\hline 4 & 1,899 & 60 & 27 & 20 & -- & - & - & -- & - & - & - & -- & $\cdots$ & 21 & 15 & 13 \\
\hline
\end{tabular}


\$0 per square meter, respectively, without federal tax considerations, and $\$ 530, \$ 73, \$ 0, \$ 0, \$ 11$, and $\$ 0$, respectively, when all tax credits are claimed by the irrigator in the 25 percent federal income tax bracket.

Detailed results showing the relationship between turbine size and investment value per square meter at different energy price scenarios are presented graphically in Figures D-1 through D-7 in Appendix D. General$1 y$, the results indicate that the highest values per meter occur at the smallest feastble turbine sizes for the regions with the most wind power. As the amount of wind power decreases, the highest value turbine size Increases, with all other factors held constant. Another observation is that the curves with the highest investment values per square meter tend to occur at higher turbine sizes under the lower energy price scenarios, unless the monthly use rate limit (discontinuity) is reached first.

Stand alone wind systems appear to have reasonable potential in wind regions $A$ and.B for irrigators who cannot shift to electricity or natural gas. Estimated investment values for all situations in the other five regions are well below the current cost of about $\$ 250 / \mathrm{m}^{2}$ for prototype wind turbine units. 
THIS PAGE

\section{WAS INTENTIONALLY LEFT BLANK}


An irrigator anticipating the replacement of a conventionally powered Irrigation pumping unit should consider the costs of alternative source of conventional energy before deciding to invest in wind turbines. For example, electricity and natural gas had economic advantages over wind power under all energy price scenarios in this study. If electricity or natural gas is immediately available without large hook-up charges, then, clearly, their use is a less expensive method for pumping irrigation water.

The best opportunities appear to replace diesel and LPG in the Southern High Plains (Region $A$ ) and diesel in the Northern High Plains (Region B). Investment values appear to be high enough for wind-assist with and without sale of surplus electricity in Region A under both the high and medium energy price scenario, for the replacement of diesel and LPG. Under the high energy price scenario in Region $B$, wind turbines almost merit consideration for replacing diesel, if the irrigator is under the 25 percent federal tax bracket, and they merit consideration for irrigators under the 50 percent federal income tax bracket. It appears that no other region merits serious consideration at this time for wind assist irrigation systems.

Wind assist with sale of surplus electricity is more attractive economically than without it. Under this alternative, the investment per $\mathrm{m}^{2}$ for a wind turbine under the high energy price scenario, with a 10 percent discount rate, ranged from $\$ 217$ per $\mathrm{m}^{2}$ in Region $A$ to $\$ 21$ per $\mathrm{m}^{2}$ In Region G. With all tax credits claimed, the maximum investment per $\mathrm{m}^{2}$ for wind turbines ranged from $\$ 315$ in Region $A$ to $\$ 31$ in Region $G$ for a person in the 25 percent federal income tax bracket. Under the medium energy price scenario, the investment ranged from $(-) \$ 146 / \mathrm{m}^{2}$ in Region $G$ to $(-) \$ 2 / \mathrm{m}^{2}$ in Region $A$, and when federal tax credits were included, it ranged from $\$ 212 / \mathrm{m}^{2}$ in Region $A$ to $(-) \$ 2 / \mathrm{m}^{2}$ in Region $G$. Investment values appear to be high enough in Region $A$ under hoth the high and medium energy price scenarios to merit serious considerations. In Region $B$, the investment values almost merit consideration under the 25 percent federal tax bracket, and they merit serious consideration under the 50 percent federal income tax bracket. In the other regions, the values do not appear high enough to merit serious consideration at this time. 
Replacing conventional fuels does not appear to be a viable alternative in any of the other regions. Gasoline appears to be used in large quantities only in the Midwest, where irrigation is only supplemental, and is only used for short perfods during the irrigation season. Electricity is a relatively cheap source of energy for most areas under Investigation.

Stand alone wind systems appear to have reasonable potential in Regions A and B for irrigators who cannot shift to electricity or natural gas. When all federal incentives and taxes are deducted, stand alone wind systems appear to have reasonable potential for 1rrigators using diesel and LPG under the medium and low energy price scenartos in Region A, medium energy price scenario in Region $B$, and the high energy price scenario for diesel in Region G. Estimated investment values for all situations in the other four rcgions are well below the current cost of about $\$ 200 \mathrm{~m}^{2}$ for prototype wind turbine units.

What irrigators can afford to pay for wind turbines depends not only on what they are worth, but also on the irrigator's ability to finance them. The fact that something is a good investment is of little significance unless it is also possible for potential investors to acquire the necessary capital. The potential investors must either have the necessary cash or be able to borrow the money under terms consistent with their repayment capacity.

Generally speaking, it seems unlikely that potentlal investors would have trouble financing wind systems. Generally, wind turbines would probably be purchased in particularly good income years so that only a small part, if any, of the required funds would need to be borrowed. A second consideration is that the size of the investment, e.g., $\$ 50,000$ $\left(200 \mathrm{~m}^{2} \times \$ 250 / \mathrm{m}^{2}\right)$, is small relative to the cost of otlier 1 tems used in today's agriculture. Still another factor that diminishes the 1ikelihood of financing problems is the fact that irrigators almost. always have the option of using their land equity to finance long-term needs if other alternatives are not feasible or attractive.

This study indicates that producers in several situations may find wind turbines a viable investment, especially producers who must otherwise use diesel or LPG in Regions $A$ and B. There are, however, additional 
considerations. 1) The results were based on average monthly wind data for broad geographical areas, and may not fit each individual case (A producer would find it desirable to obtain daily or weekly wind energy values and compare wind energy available to needs for pumping.); 2) The performance coefficient of the turbine may vary from the 20 percent used in this study; 3) There may be possibilities for modifying irrigation and crop management practices to take greater advantage of wind power; and 4) The existance of state tax provisfons not considered in the study may make wind energy more attractive in particular states.

The above considerations clearly mertt further investigation in view of the economic potential that wind energy for irrigation pumping appears to have. What is provided in this study was essentially a first cut at estimating target investment values for wind turbines for pumping irrigation water. Until more is known about the above factors, significant uncertainties regarding the economic value of wind systems will continue to exist. 
THIS PAGE

WAS INTENTIONALLY

LEFT BLANK 
Climatic Atlas of the United States. United States Department of Commerce, Environmental Services Administration, Environmental Data Service, Washington, D.C., 80 pages, 1968.

E11iott, D.L., Synthesis of National Wind Energy Assessments, BNWL-2220, WIND-5, Battelle, Pacific Northwest Laboratories, Richland, Washington, 47 pages, July 1977.

Gilley, James R., On-Farm U.S. Irrigation Pumping Plants, Southwest Research and Development Company, Las Cruces, New Mexico, April 1980.

Reed, Jack W., "Wind Power Climatology of the U.S.", supplement, SAND 78-1620, Sandia Laboratories, Albuquerque, New Mexico, page 98, 1979. 
THIS PAGE

WAS INTENTIONALLY

LEFT BLANK 
APPENDIX A

Turbine and Reservoir Sizing Analysis 
INPUT DATA:

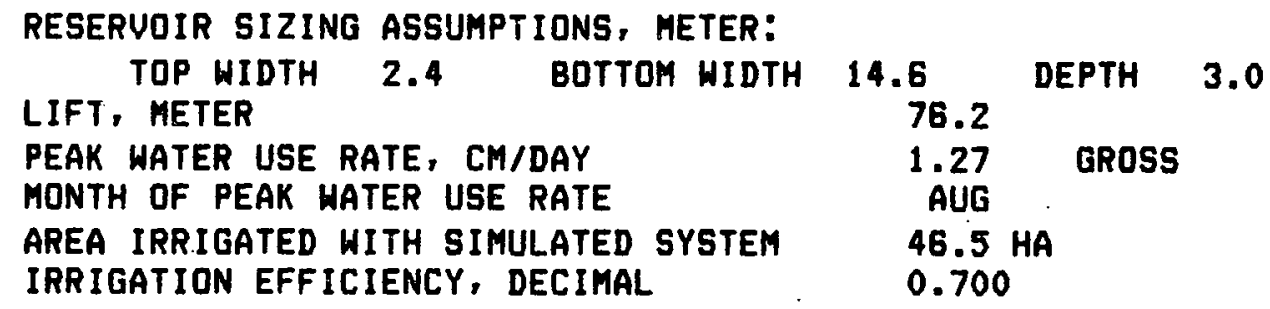

MONTHLY VALUES

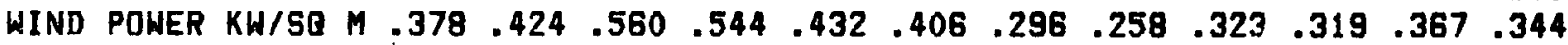

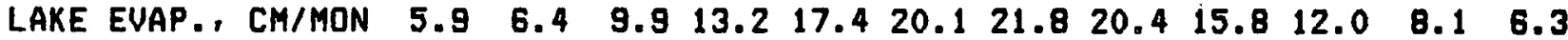

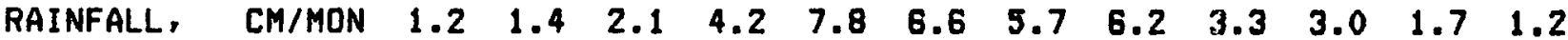

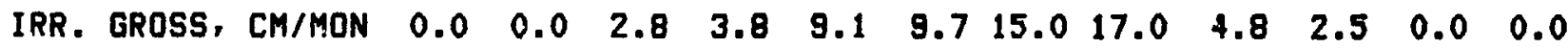

RESULTS:

NE'T POWER REQUIREMENT

INTERNAL COMBUSTION ENGINE SIZE 102.1 KW ELECTRIC MOTOR SIZE

$$
\begin{array}{rl}
51.1 & \mathrm{KH} \\
102.1 & \mathrm{KW} \\
75.0 & \mathrm{KW}
\end{array}
$$

$\begin{array}{lll}\text { ENERGY SAUED }= & 91630 . & \text { KW-HOURS OF ELECTRIC } \\ \text { ENERGY SAUED }= & 28998 . \quad \text { LITERS OF DIESEL } \\ \text { ENERGY SAUED }= & 45949 . \quad \text { LITERS OF PROPANE } \\ \text { ENEROY SAUED }= & 35321 . & \text { CUBIC M OF NAT. GAS }\end{array}$

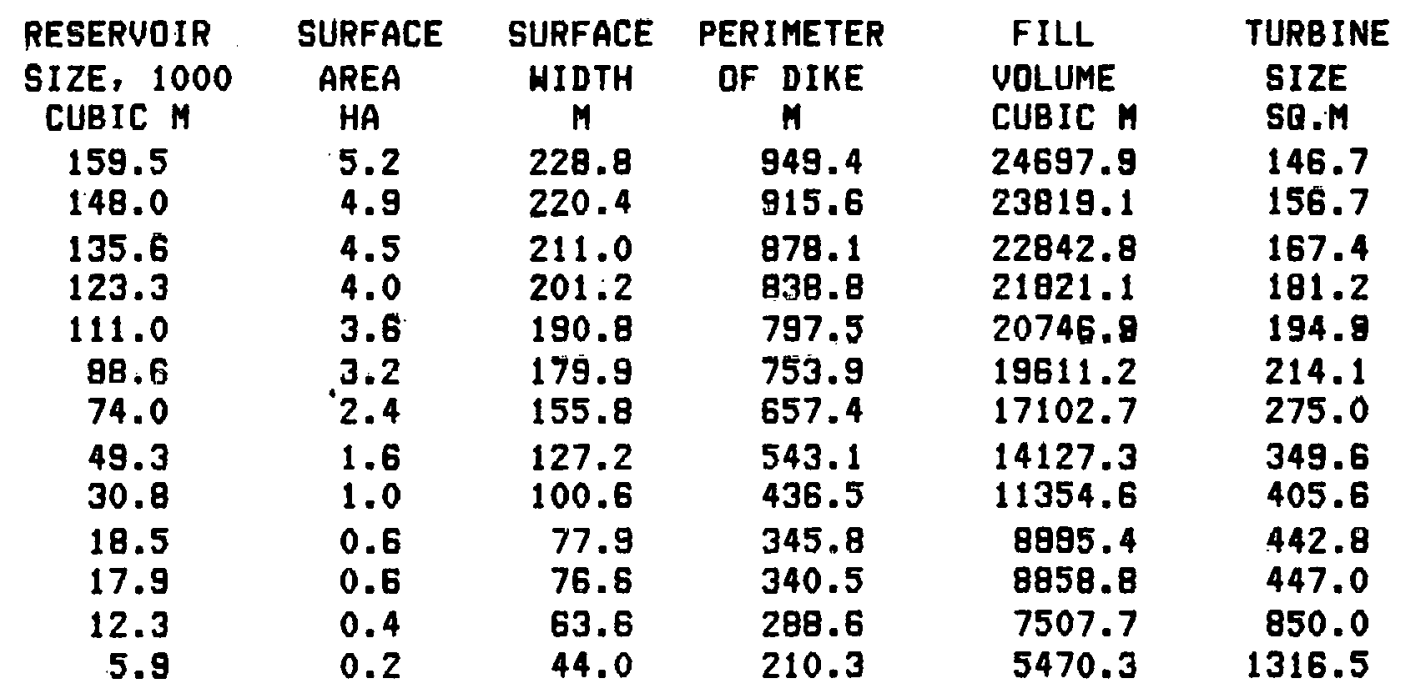


INPUT DATA:

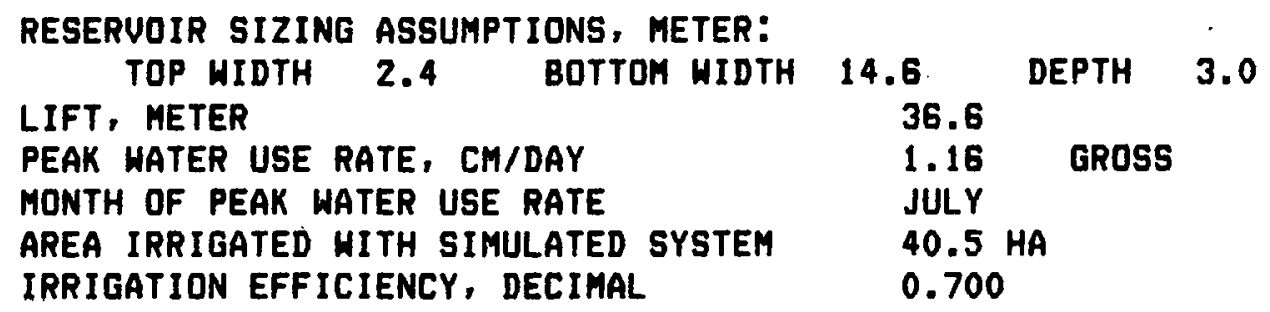

\begin{tabular}{|c|c|c|c|c|c|c|c|c|c|c|c|c|c|c|}
\hline \multirow{3}{*}{\multicolumn{2}{|c|}{$\begin{array}{l}\text { WIND POWER } \\
\text { LAKE EUAP. } \\
\text { RAINFALL, } \\
\text { IRR. GROSS, }\end{array}$}} & & \multicolumn{12}{|c|}{ MONTHLY UALUES } \\
\hline & & KW & $\begin{array}{r}\text { JAN } \\
.326\end{array}$ & $\begin{array}{c}\text { FEBR } \\
.311\end{array}$ & $\begin{array}{r}\text { MAR } \\
.430\end{array}$ & $\begin{array}{r}\text { APR } \\
.481\end{array}$ & $\begin{array}{r}\text { MAY } \\
.381\end{array}$ & $\begin{array}{l}\text { JUNE } \\
.283\end{array}$ & $\begin{array}{l}\text { JULY } \\
.219\end{array}$ & $\begin{array}{r}\text { AUG } \\
.219\end{array}$ & $\begin{array}{l}\text { SEPT } \\
.244\end{array}$ & $\begin{array}{r}\text { OCT } \\
.281\end{array}$ & $\begin{array}{r}\text { NOV } \\
.370\end{array}$ & $\begin{array}{r}\text { DEC } \\
.293\end{array}$ \\
\hline & & $\begin{array}{l}\text { CM/MON } \\
\text { CM/MON } \\
\text { CM/MON }\end{array}$ & $\begin{array}{l}3.6 \\
1.2 \\
0.0\end{array}$ & $\begin{array}{l}4.1 \\
1.5 \\
0.0\end{array}$ & $\begin{array}{l}6.3 \\
2.8 \\
0.0\end{array}$ & $\begin{array}{l}9.4 \\
5.3 \\
0.3\end{array}$ & $\begin{array}{r}13.0 \\
8.7 \\
2.3\end{array}$ & $\begin{array}{r}15.4 \\
10.3 \\
5.6\end{array}$ & $\begin{array}{r}17.2 \\
6.7 \\
22.1\end{array}$ & $\begin{array}{r}15.8 \\
5.9 \\
22.1\end{array}$ & $\begin{array}{r}11.8 \\
5.2 \\
11.9\end{array}$ & $\begin{array}{l}8.6 \\
2.6 \\
0.0\end{array}$ & $\begin{array}{l}5.2 \\
1.8 \\
0.0\end{array}$ & 0. \\
\hline
\end{tabular}

RESULTS:

NET POWER REQUIREMENT

INTERNAL COMBUSTION ENGINE SIZE

ELECTRIC MOTOR SIZE
$19.5 \mathrm{KH}$

$39.0 \mathrm{KH}$

$28.6 \mathrm{KH}$
ENERGY SAUED = ENERGY SAVED = ENERGY SAUED= ENERGY SAUED=
37945. KW-HOURS OF ELECTRIC

12009. LITERS OF DIESEL

19028. LITERS OF PROPANE

14627. CUBIC M OF NAT. GAS

\begin{tabular}{|c|c|c|c|c|c|}
\hline $\begin{array}{l}\text { RESERUOIR } \\
\text { SIZE, } 1000\end{array}$ & $\begin{array}{l}\text { SURFACE } \\
\text { AREA }\end{array}$ & $\begin{array}{c}\text { SURFACE } \\
\text { HIDTH }\end{array}$ & $\begin{array}{c}\text { PERIMETER } \\
\text { OF DIKE }\end{array}$ & $\begin{array}{l}\text { FILL } \\
\text { VOLUME }\end{array}$ & $\begin{array}{l}\text { TURB INE } \\
\text { SIZE }\end{array}$ \\
\hline $\begin{array}{c}\text { CUBIC } \\
195.1\end{array}$ & $\begin{array}{l}\text { HA } \\
6.4\end{array}$ & $\stackrel{M}{M}$ & $M_{1046.4}^{M}$ & $\begin{array}{l}\text { CUBIC M } \\
27221.5\end{array}$ & $\begin{array}{c}\text { SQ.M } \\
70.5\end{array}$ \\
\hline $\begin{array}{l}184.9 \\
172.6\end{array}$ & $\begin{array}{l}6.1 \\
5.7\end{array}$ & $\begin{array}{l}246.4 \\
238.0\end{array}$ & $\begin{array}{r}1019.7 \\
986.2\end{array}$ & $\begin{array}{l}26525.7 \\
25656.4\end{array}$ & $\begin{array}{l}79.1 \\
92.2\end{array}$ \\
\hline $\begin{array}{l}148.0 \\
123.3\end{array}$ & $\begin{array}{l}4.9 \\
4.0\end{array}$ & $\begin{array}{l}220.4 \\
201.2\end{array}$ & $\begin{array}{l}915.6 \\
838.8\end{array}$ & $\begin{array}{l}23819.1 \\
21821.1\end{array}$ & $\begin{array}{l}122.0 \\
151.4\end{array}$ \\
\hline $\begin{array}{l}98.6 \\
74.0\end{array}$ & $\begin{array}{l}3.2 \\
2.4\end{array}$ & $\begin{array}{l}179.9 \\
155.8\end{array}$ & $\begin{array}{l}753.9 \\
657.4\end{array}$ & $\begin{array}{l}19611.2 \\
17102.7\end{array}$ & $\begin{array}{l}181.1 \\
223.2\end{array}$ \\
\hline $\begin{array}{r}49.3 \\
24.7 \\
20.2 \\
12.3 \\
6.2\end{array}$ & $\begin{array}{l}1.6 \\
0.8 \\
0.7 \\
0.4 \\
0.2\end{array}$ & $\begin{array}{r}127.2 \\
90.0 \\
81.4 \\
63.6 \\
45.0\end{array}$ & $\begin{array}{l}543.1 \\
394.0 \\
358.7 \\
288.6 \\
214.1\end{array}$ & $\begin{array}{r}14127.3 \\
10249.6 \\
9357.8 \\
7507.7 \\
5568.8\end{array}$ & $\begin{array}{l}269.7 \\
316.4 \\
324.9 \\
460.3 \\
568.6\end{array}$ \\
\hline 4.7 & 0.2 & 39.3 & 191.2 & 4973.8 & 591.9 \\
\hline
\end{tabular}


INPUT DATA:

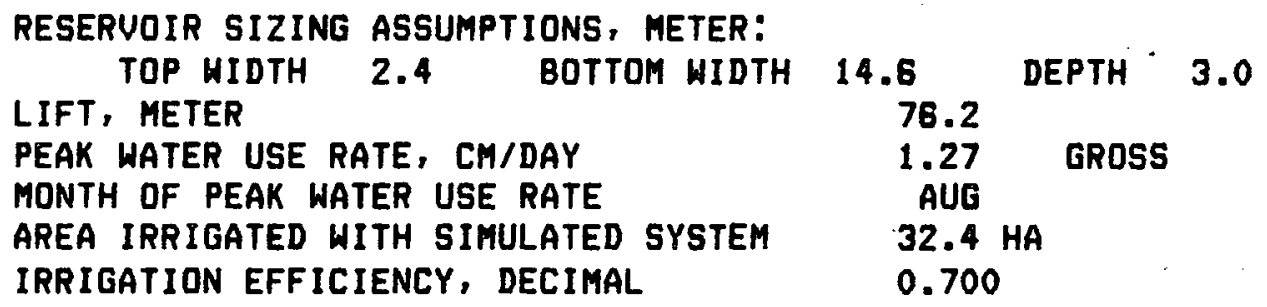

MONTHLY VALUES

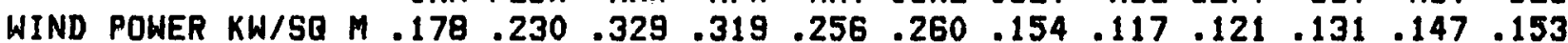

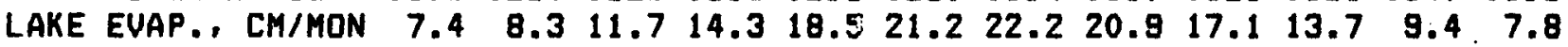

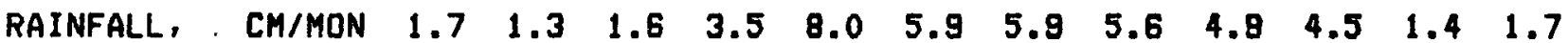

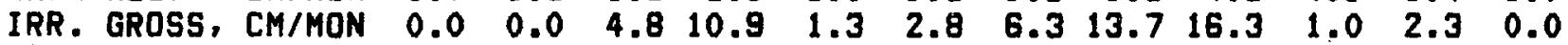

RESULTS:

NET POWER REQUIREMENT INTERNAL COMBUSTION ENGINE SIZE ELECTRIC MOTOR SIZE
$35.5 \mathrm{KH}$

$71.1 \mathrm{KH}$

$52.2 \mathrm{KH}$

ENERGY SAVED $=$ 58493. KW-HOURS OF ELECTRIC ENERGY SAUED $=18511$. LITERS OF DIESEL ENERGY SAUED $=$ 2933\%, LITERS OF PROPANE ENERGY SAUED $=$ 22548. CUBIC M OF NAT. GAS

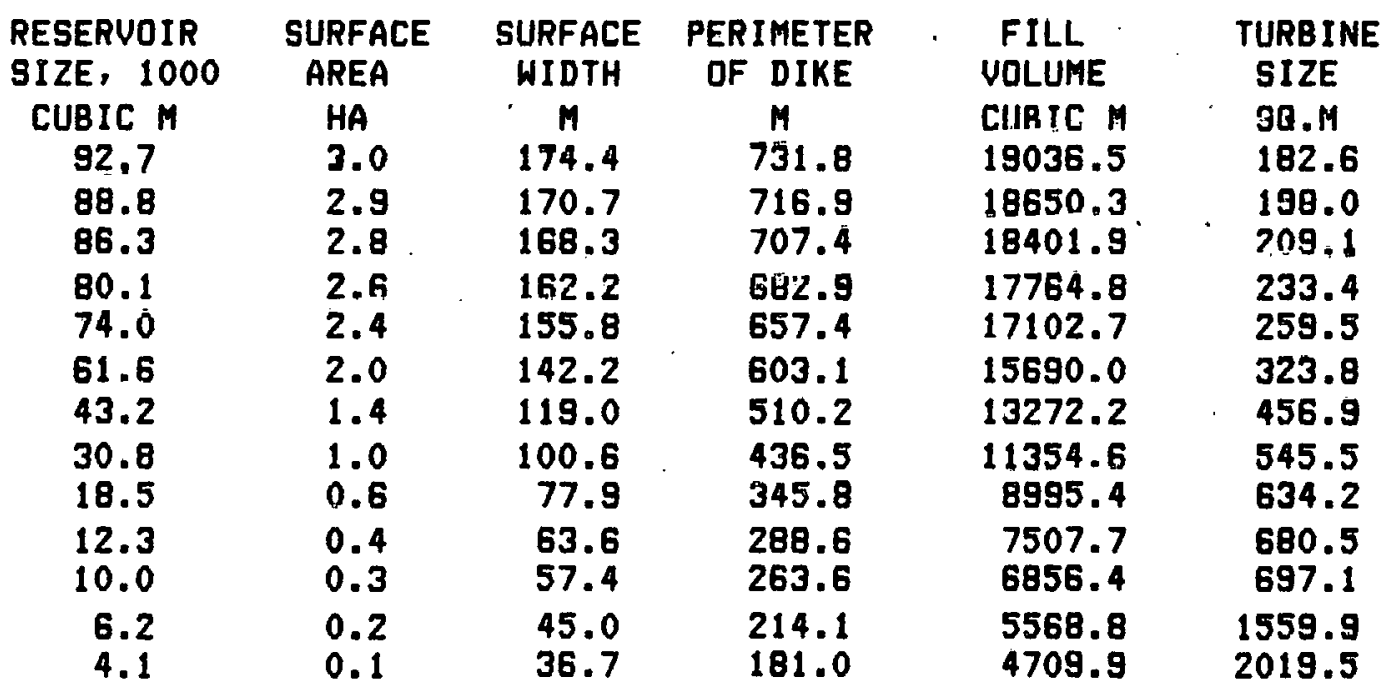


INPUT DATA:

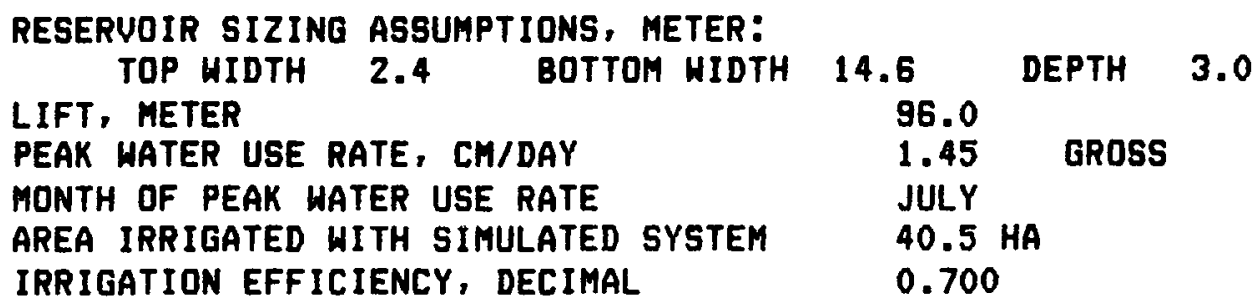

MONTHLY VALUES

JAN FEBR MAR APR MAY JUNE JULY AUG SEPT OCT NOU DEC

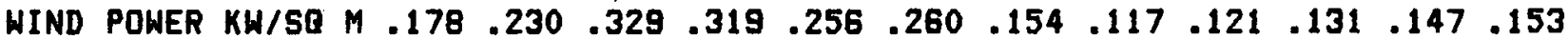

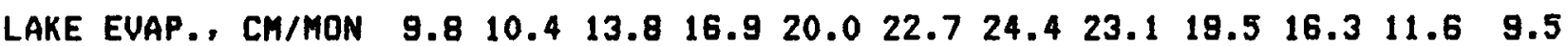

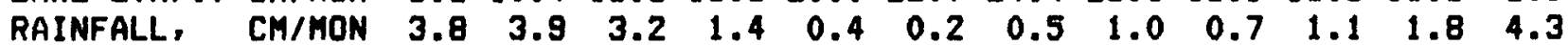

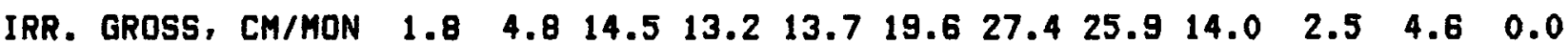

RESULTS:

NET POWER REQUIREMENT

INTERNAL COMBUSTION ENGINE SIZE

ELECTRIC MOTOR SIZE
$64.0 \mathrm{KH}$

$127.9 \mathrm{KW}$

$94.0 \mathrm{KH}$

ENERGY SAUED $=$ 220080. KH-HOURS OF ELECTRIC ENERGY SAUED $=$ 69649. LITERS OF DIESEL ENERGY SAUED $=110361$. LITERS OF PROPANE ENERGY SAUED $=$ 84837. CUBIC M OF NAT. GAS

\begin{tabular}{|c|c|c|c|c|c|}
\hline $\begin{array}{c}\text { RESERUOIR } \\
\text { SIZE, } 1000 \\
\text { CUBIC } M \\
223.6 \\
197.3 \\
172.6 \\
148.0 \\
111.0 \\
74.0 \\
49.3 \\
25.1 \\
24.7 \\
5.9\end{array}$ & $\begin{array}{c}\text { SURFACE } \\
\text { AREA } \\
\text { HA } \\
7.3 \\
6.5 \\
5.7 \\
4.9 \\
3.6 \\
2.4 \\
1.6 \\
0.8 \\
0.8 \\
0.2\end{array}$ & $\begin{array}{c}\text { SURFACE } \\
\text { WIDTH } \\
M \\
270.9 \\
254.5 \\
238.0 \\
220.4 \\
190.8 \\
155.8 \\
127.2 \\
90.7 \\
80.0 \\
43.9\end{array}$ & $\begin{array}{c}\text { PERIMETER } \\
\text { OF DIKE } \\
M \\
1117.8 \\
1052.0 \\
986.2 \\
915.8 \\
797.5 \\
657.4 \\
543.1 \\
396.9 \\
394.0 \\
209.7\end{array}$ & $\begin{array}{l}\text { FILL } \\
\text { VOLUME } \\
\text { CUBIC M } \\
29079.0 \\
27366.5 \\
25656.4 \\
23810.1 \\
20746.9 \\
17102.7 \\
14127.3 \\
10324.8 \\
10249.6 \\
5456.0\end{array}$ & $\begin{array}{l}\text { TURB INE } \\
\text { SIZE } \\
\text { SQ.M } \\
700.7 \\
769.3 \\
833.5 \\
838.1 \\
1113.1 \\
1319.5 \\
1499.9 \\
1676.3 \\
1698.8 \\
2761.8\end{array}$ \\
\hline
\end{tabular}


INPUT DATA:

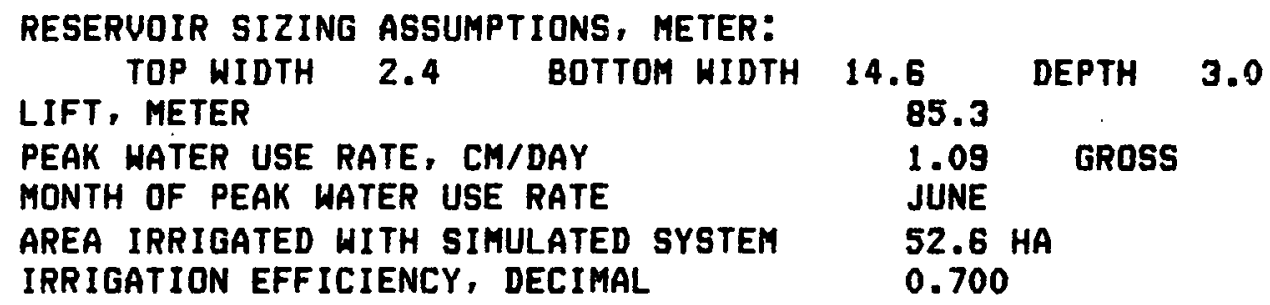

RESULTS:

NET POWER REQUIREMENT

INTERNAL COMBUSTIDN ENGINE SIZE ELECTRIC MOTOR SIZE
MONTHLY VALUES

JAN FEBR MAR APR MAY JUNE JULY AUG SEPT OCT NOU DEC

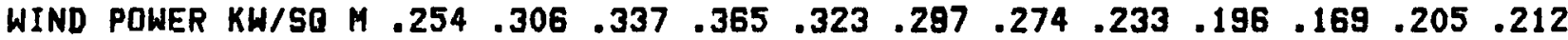

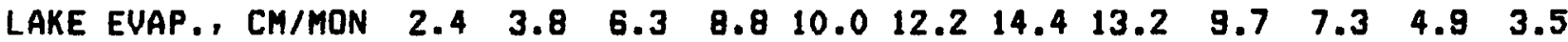

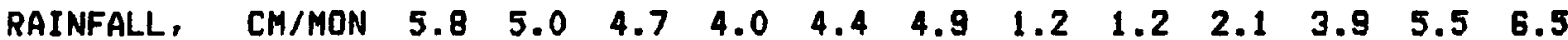

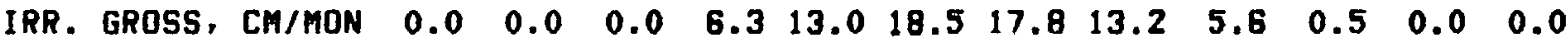

\begin{tabular}{|c|c|c|c|c|}
\hline 9 & $\begin{array}{r}424 \\
673\end{array}$ & $\begin{array}{c}K H-H \\
L \\
L\end{array}$ & & $r \pi$ \\
\hline & & & & \\
\hline
\end{tabular}

\begin{tabular}{|c|c|c|c|c|c|}
\hline $\begin{array}{l}\text { RESERUOIR } \\
\text { SIZE, } 1000 \\
\text { CUBIC } M \\
209.9 \\
203.4\end{array}$ & $\begin{array}{c}\text { SURFACE } \\
\text { AREA } \\
\text { HA } \\
6.9 \\
6.7\end{array}$ & $\begin{array}{c}\text { SURFACE } \\
\text { WIDTH } \\
\text { M } \\
262.5 \\
258.4\end{array}$ & $\begin{array}{c}\text { PER IMETER } \\
\text { OF DIKE } \\
M \\
1084.1 \\
1067.8\end{array}$ & $\begin{array}{l}\text { FILL } \\
\text { UOLUME } \\
\text { CUBIC M } \\
20201.7 \\
27777.1\end{array}$ & $\begin{array}{l}\text { TURB INE } \\
\text { SIZE } \\
\text { SB.M } \\
285 . \overline{2} \\
293.8\end{array}$ \\
\hline $\begin{array}{l}197.3 \\
177.0\end{array}$ & $\begin{array}{l}6.5 \\
5.7\end{array}$ & $\begin{array}{l}254.5 \\
238.0\end{array}$ & $\begin{array}{r}1052.0 \\
986.2\end{array}$ & $\begin{array}{l}27366.5 \\
25656.4\end{array}$ & $\begin{array}{l}302.3 \\
335.8\end{array}$ \\
\hline $\begin{array}{l}149.0 \\
123.3\end{array}$ & $\begin{array}{l}4.3 \\
4.0\end{array}$ & $\begin{array}{l}220.4 \\
201.2\end{array}$ & $\begin{array}{l}915.6 \\
838.8\end{array}$ & $\begin{array}{l}23819.1 \\
21821.1\end{array}$ & $\begin{array}{l}370.2 \\
410.2\end{array}$ \\
\hline $\begin{array}{l}98.6 \\
74.0\end{array}$ & $\begin{array}{l}3.2 \\
2.8\end{array}$ & $\begin{array}{l}179.9 \\
155.8\end{array}$ & $\begin{array}{l}753.9 \\
657.4\end{array}$ & $\begin{array}{l}19611.2 \\
17102.7\end{array}$ & $\begin{array}{l}450.5 \\
508.1\end{array}$ \\
\hline $\begin{array}{l}49.3 \\
24.7 \\
22.8\end{array}$ & $\begin{array}{l}1.6 \\
0.8 \\
0.7\end{array}$ & $\begin{array}{r}127.2 \\
90.0 \\
86.4\end{array}$ & $\begin{array}{l}543.1 \\
394.0 \\
379.8\end{array}$ & $\begin{array}{r}14127.3 \\
10249.6 \\
9880.2\end{array}$ & $\begin{array}{l}565.6 \\
623.3 \\
628.2\end{array}$ \\
\hline $\begin{array}{r}12.3 \\
5.7\end{array}$ & $\begin{array}{l}0.4 \\
0.2\end{array}$ & $\begin{array}{l}63.6 \\
43.3\end{array}$ & $\begin{array}{l}288.6 \\
207.5\end{array}$ & $\begin{array}{l}7507.7 \\
5398.6\end{array}$ & $\begin{array}{l}1003.3 \\
1241.1\end{array}$ \\
\hline
\end{tabular}


INPUT DATA:

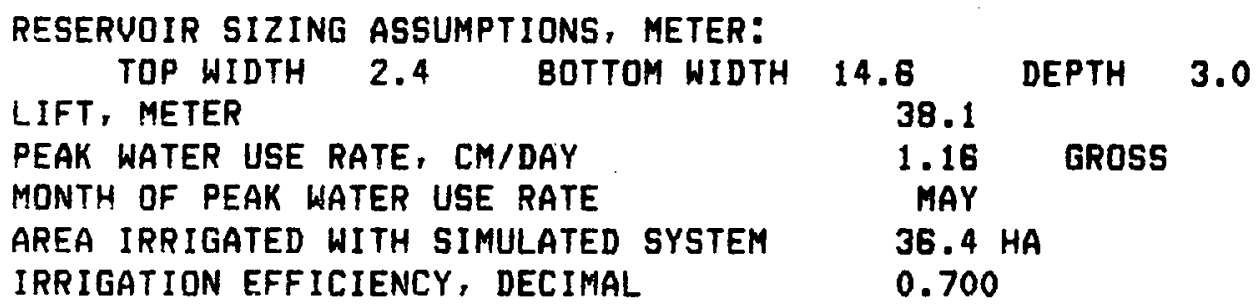

MONTHLY VALUES

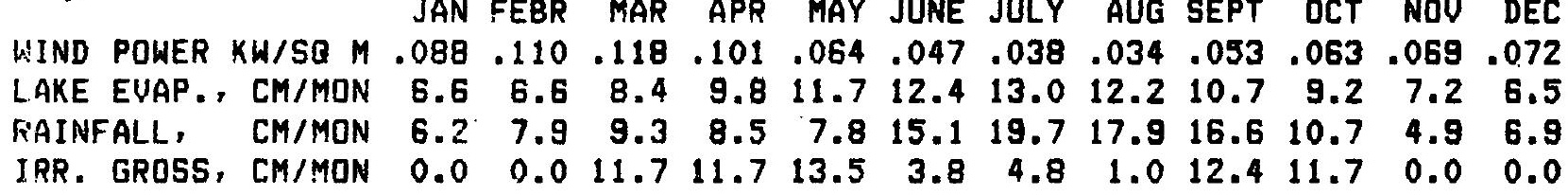

RESULTS:

NET POWER REQUIREMENT

INTERNAL COMBUSTION ENGINE SIZE

ELECTRIC MOTOR SIZE
$18.3 \mathrm{KH}$

$36.5 \mathrm{KW}$

$26.8 \mathrm{KH}$
ENERGY SAUED $=39089$. KW-HOURS OF ELECTRIC

ENERGY SAUED $=12371$. LITERS OF DIESEL

ENERGY SAVED $=19602$. LITERS OF PROPANE

ENERGY SAUED $=$ 15068. CUBIC M OF NAT. GAS

\begin{tabular}{|c|c|c|c|c|c|}
\hline RESERVOIR & SURFACE & SURFACE & PER IMETER & FILL & TURB INE \\
\hline $\begin{array}{l}\text { SIZE, } 1000 \\
\text { CUBIC } M\end{array}$ & $\begin{array}{c}\text { AREA } \\
\text { HA }\end{array}$ & WIDTH & OF DIKE & $\begin{array}{l}\text { UOLUME } \\
\text { CUBIC M }\end{array}$ & $\begin{array}{l}\text { SIZE } \\
\text { SQ.M }\end{array}$ \\
\hline $\begin{array}{l}97.6 \\
92.5\end{array}$ & $\begin{array}{l}3.2 \\
3.0\end{array}$ & $\begin{array}{l}179.0 \\
174.2\end{array}$ & $\begin{array}{l}750.2 \\
731.0\end{array}$ & $\begin{array}{l}19514.7 \\
19016.6\end{array}$ & $\begin{array}{l}278.5 \\
288.3\end{array}$ \\
\hline $\begin{array}{l}86.3 \\
80.1\end{array}$ & $\begin{array}{l}2.8 \\
2.6\end{array}$ & $\begin{array}{l}168.3 \\
162.2\end{array}$ & $\begin{array}{l}707.4 \\
682.9\end{array}$ & $\begin{array}{l}18401.9 \\
17764.8\end{array}$ & $\begin{array}{l}300.1 \\
312.2\end{array}$ \\
\hline $\begin{array}{l}74.0 \\
61.6\end{array}$ & $\begin{array}{l}2.4 \\
2.0\end{array}$ & $\begin{array}{l}155.8 \\
142.2\end{array}$ & $\begin{array}{l}657.4 \\
603.1\end{array}$ & $\begin{array}{l}17102.7 \\
15690.0\end{array}$ & $\begin{array}{l}324.1 \\
352.1\end{array}$ \\
\hline $\begin{array}{l}49.3 \\
37.0\end{array}$ & $\begin{array}{l}1.6 \\
1.2\end{array}$ & $\begin{array}{l}127.2 \\
110.2\end{array}$ & $\begin{array}{l}543.1 \\
474.9\end{array}$ & $\begin{array}{l}14127.3 \\
12353.6\end{array}$ & $\begin{array}{l}383.0 \\
416.3\end{array}$ \\
\hline $\begin{array}{l}24.7 \\
12.3 \\
11.1\end{array}$ & $\begin{array}{l}0.8 \\
0.4 \\
0.4\end{array}$ & $\begin{array}{l}90.0 \\
63.6 \\
60.3\end{array}$ & $\begin{array}{l}394.0 \\
288.6 \\
275.2\end{array}$ & $\begin{array}{r}10249.6 \\
7507.7 \\
7159.5\end{array}$ & $\begin{array}{l}507.4 \\
810.7 \\
621.2\end{array}$ \\
\hline $\begin{array}{l}6.2 \\
4.2\end{array}$ & $\begin{array}{l}0.2 \\
0.1\end{array}$ & $\begin{array}{l}45.0 \\
37.2\end{array}$ & $\begin{array}{l}214.1 \\
183.1\end{array}$ & $\begin{array}{l}5568.8 \\
4764.1\end{array}$ & $\begin{array}{l}1536.8 \\
1898.7\end{array}$ \\
\hline
\end{tabular}




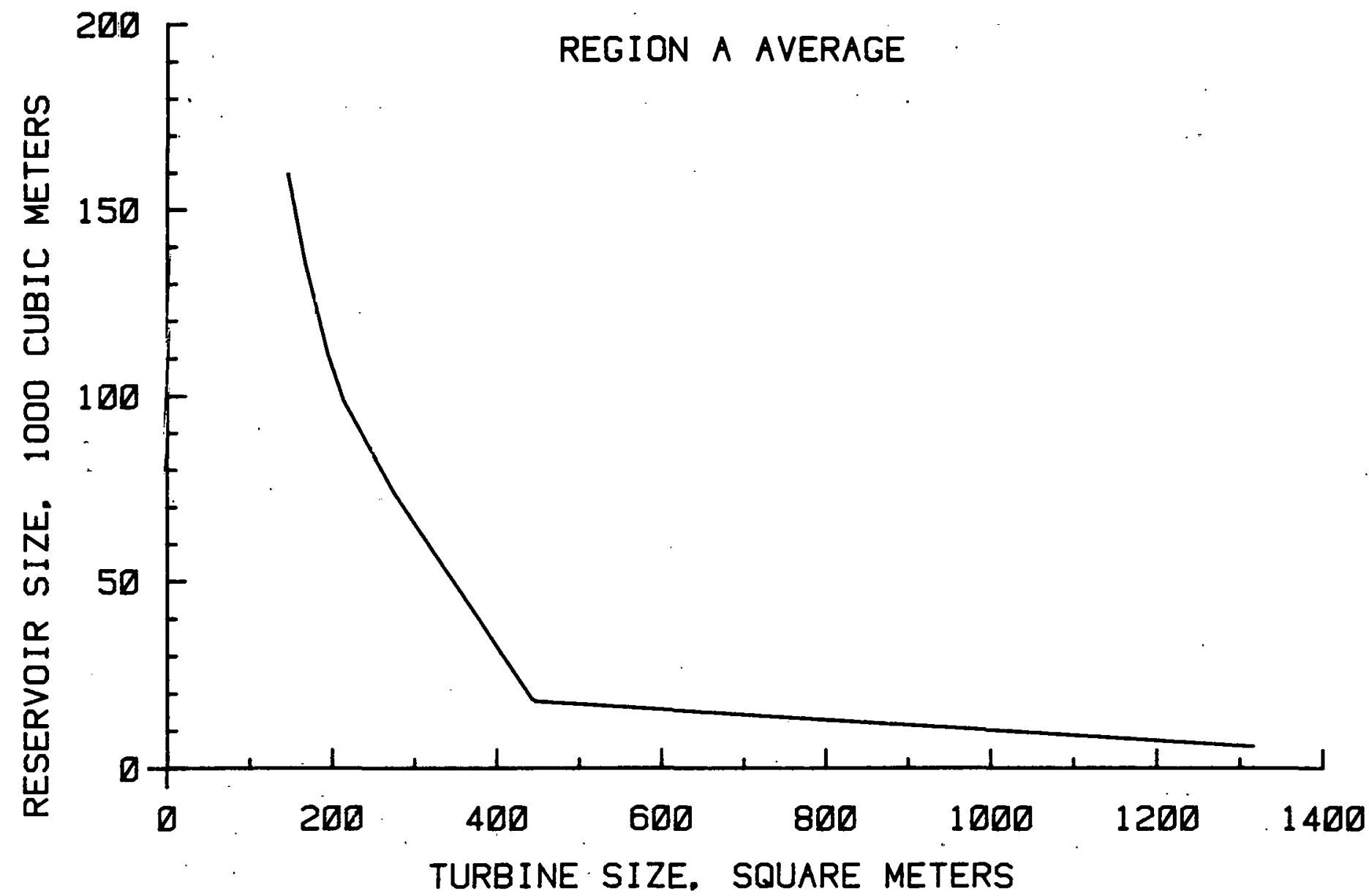

Figure A-1. Turbine size versus reservoir size - Region A. 


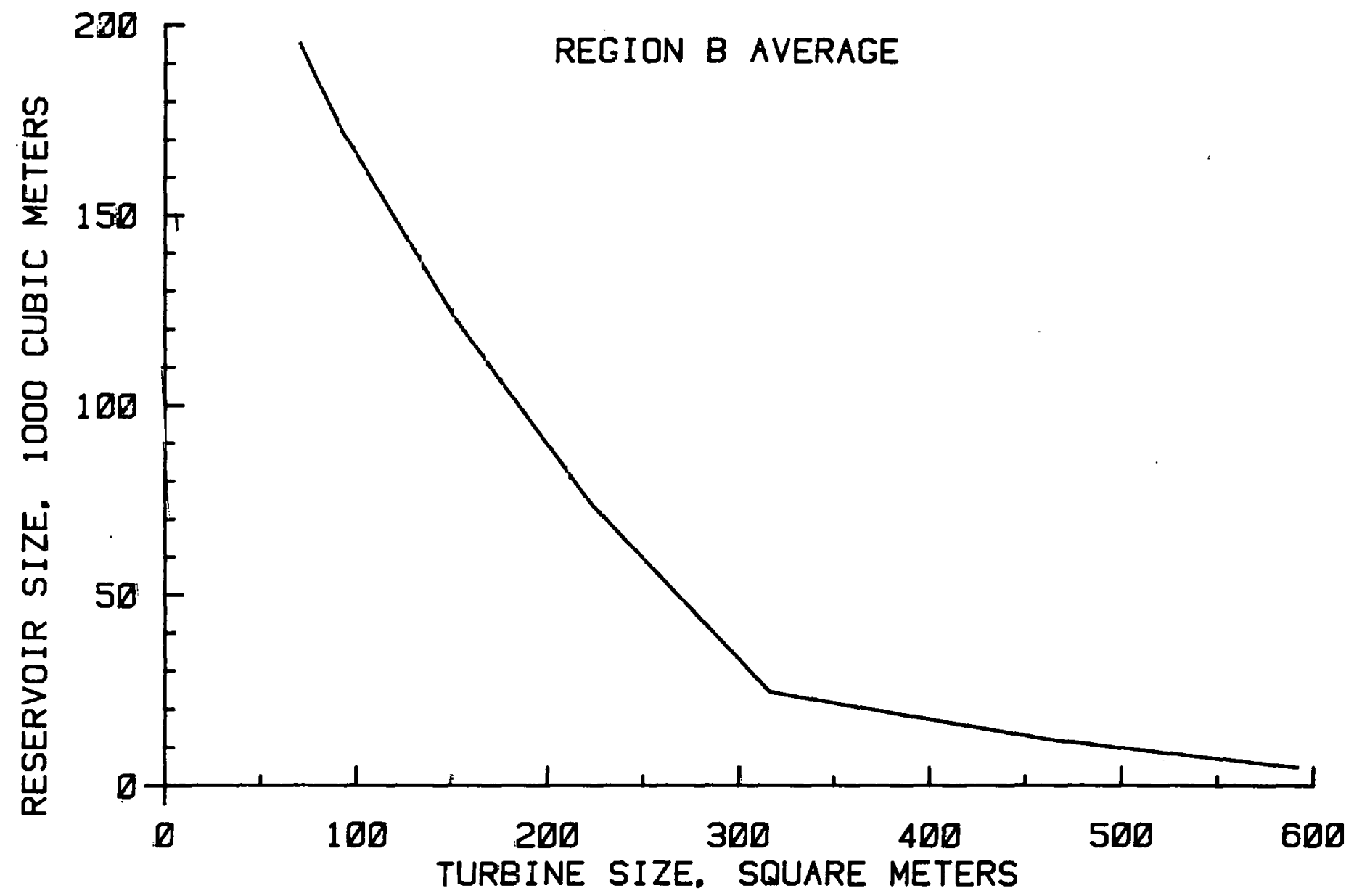

Figure A-2. Turbine size versus reservoir size - Region B. 


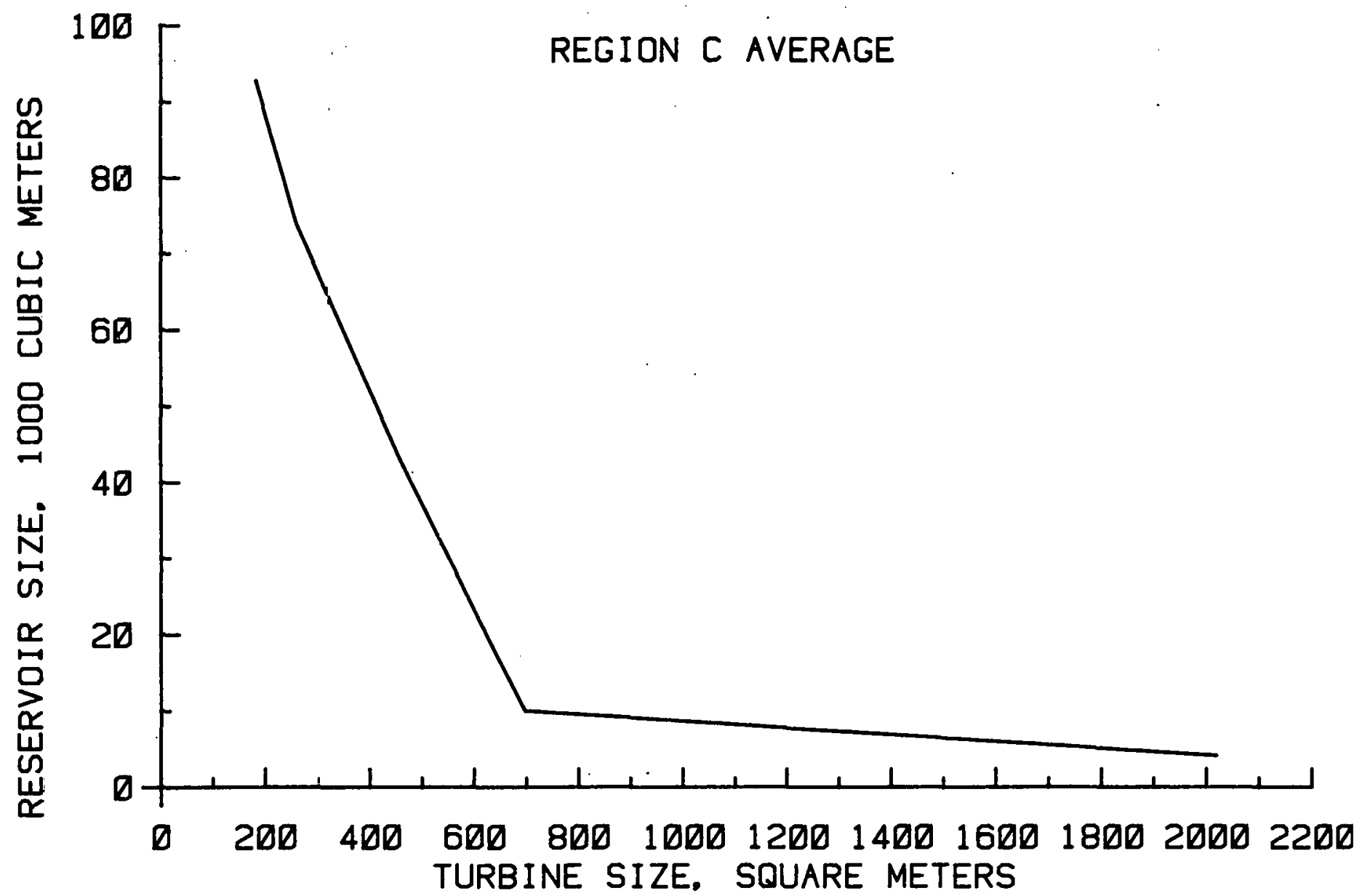

Figure A-3. Turbine size versus reservoir size - Region C. 


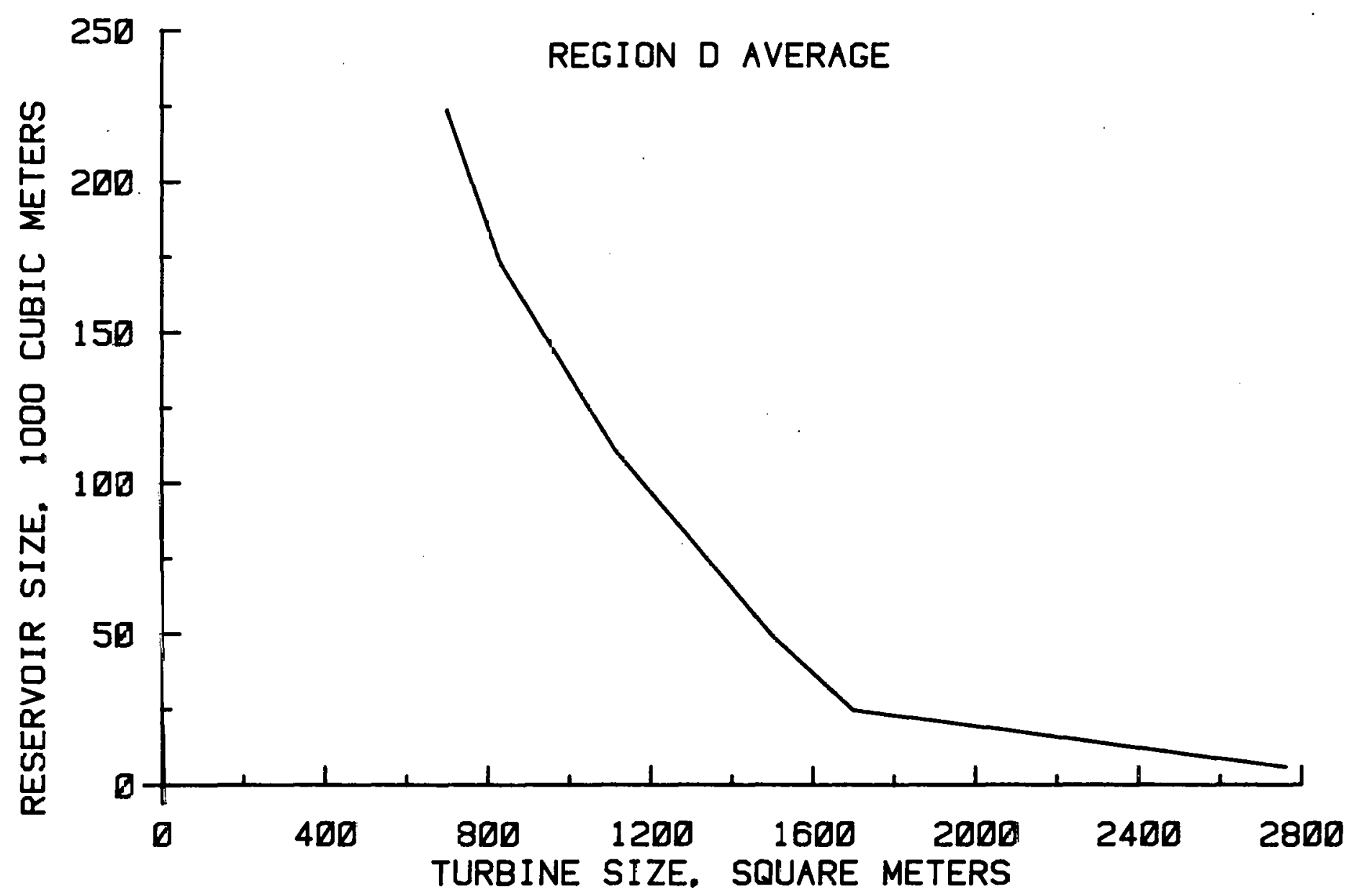

Figure A-4. Turbine size versus reservoir size - Region D. 


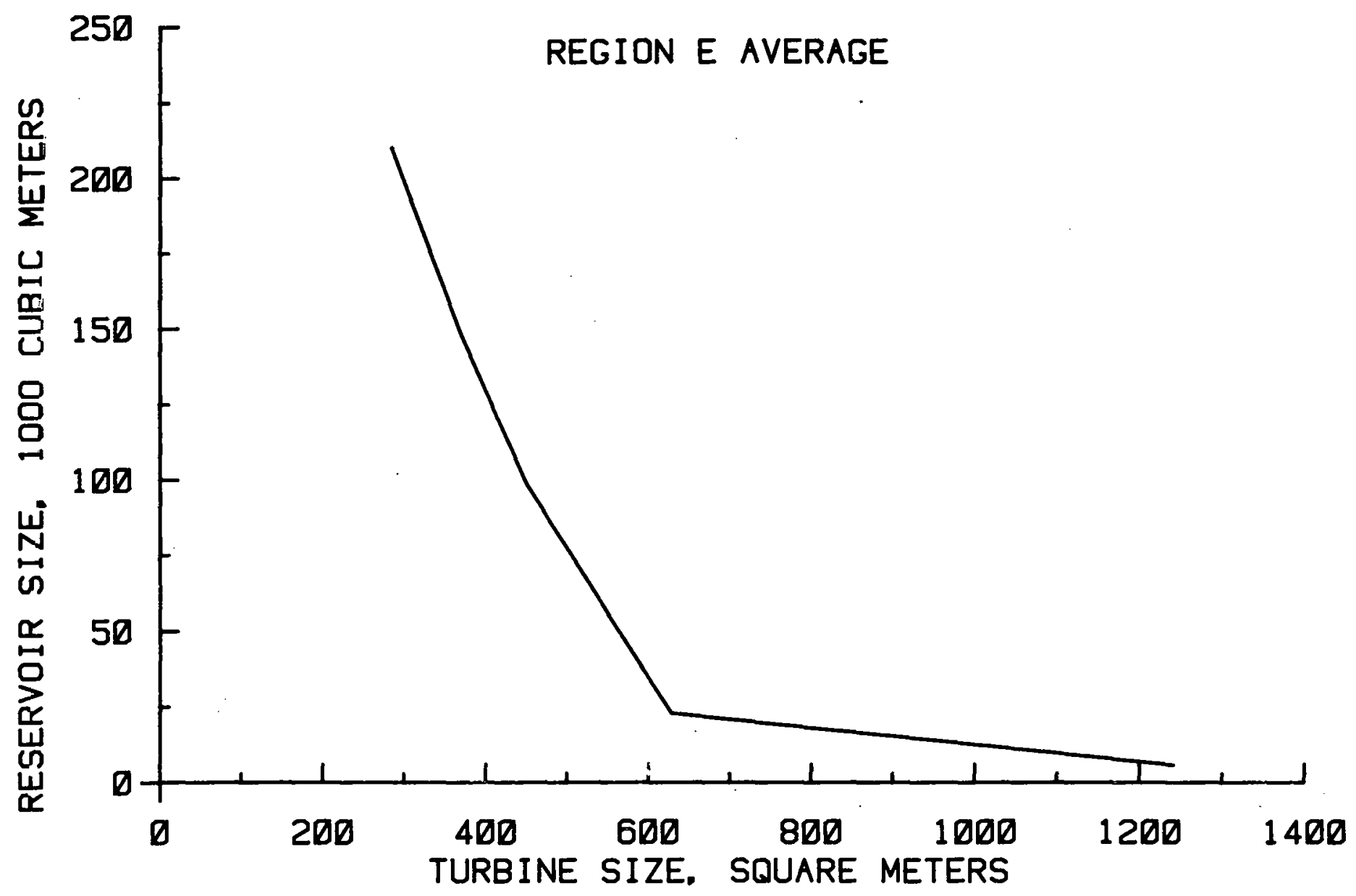

Figure A-5. Turbine size versus reservoir size - Region E. 


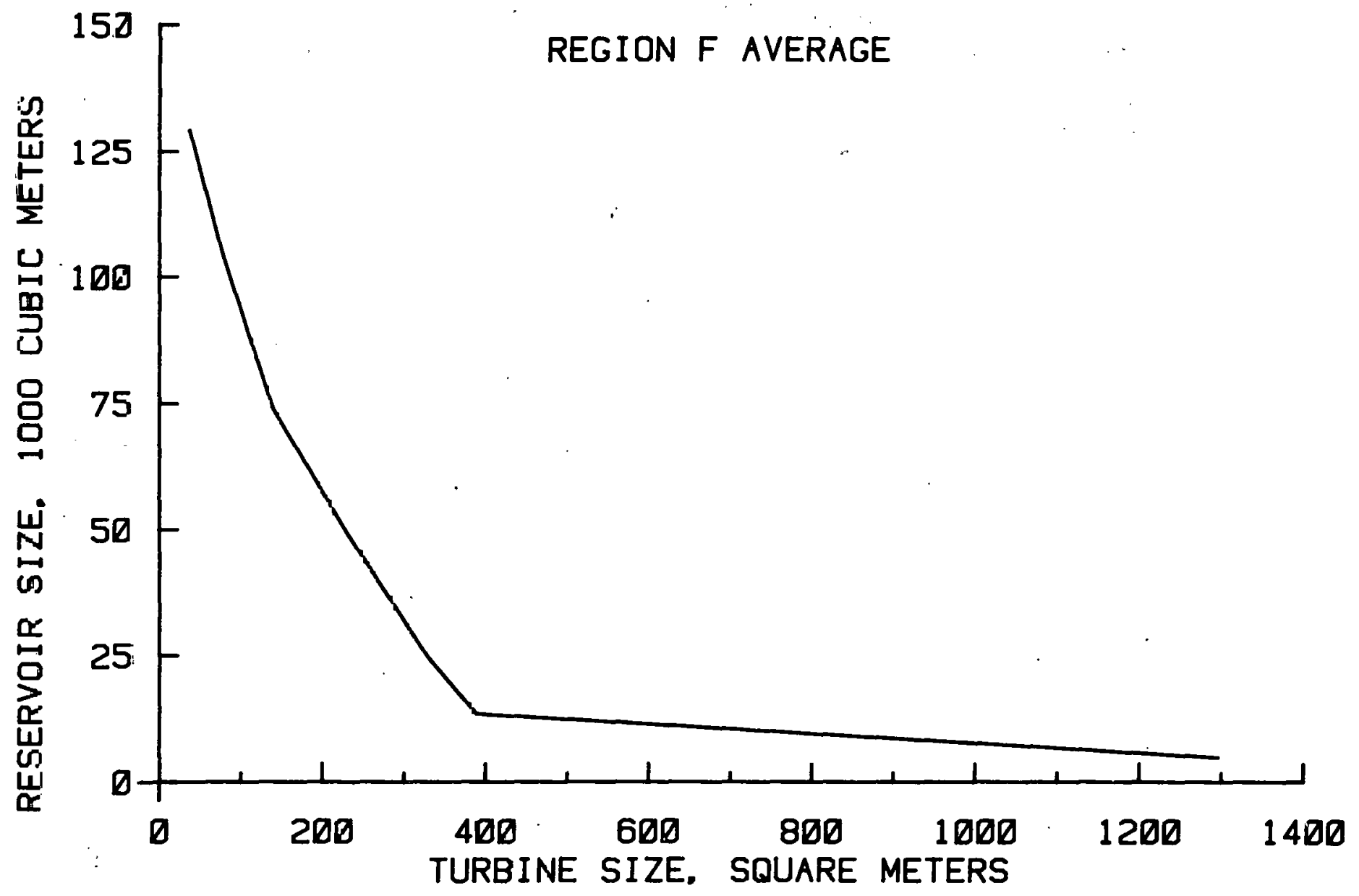

Figure A-6. Turbine size versus reservoir size - Region F. 


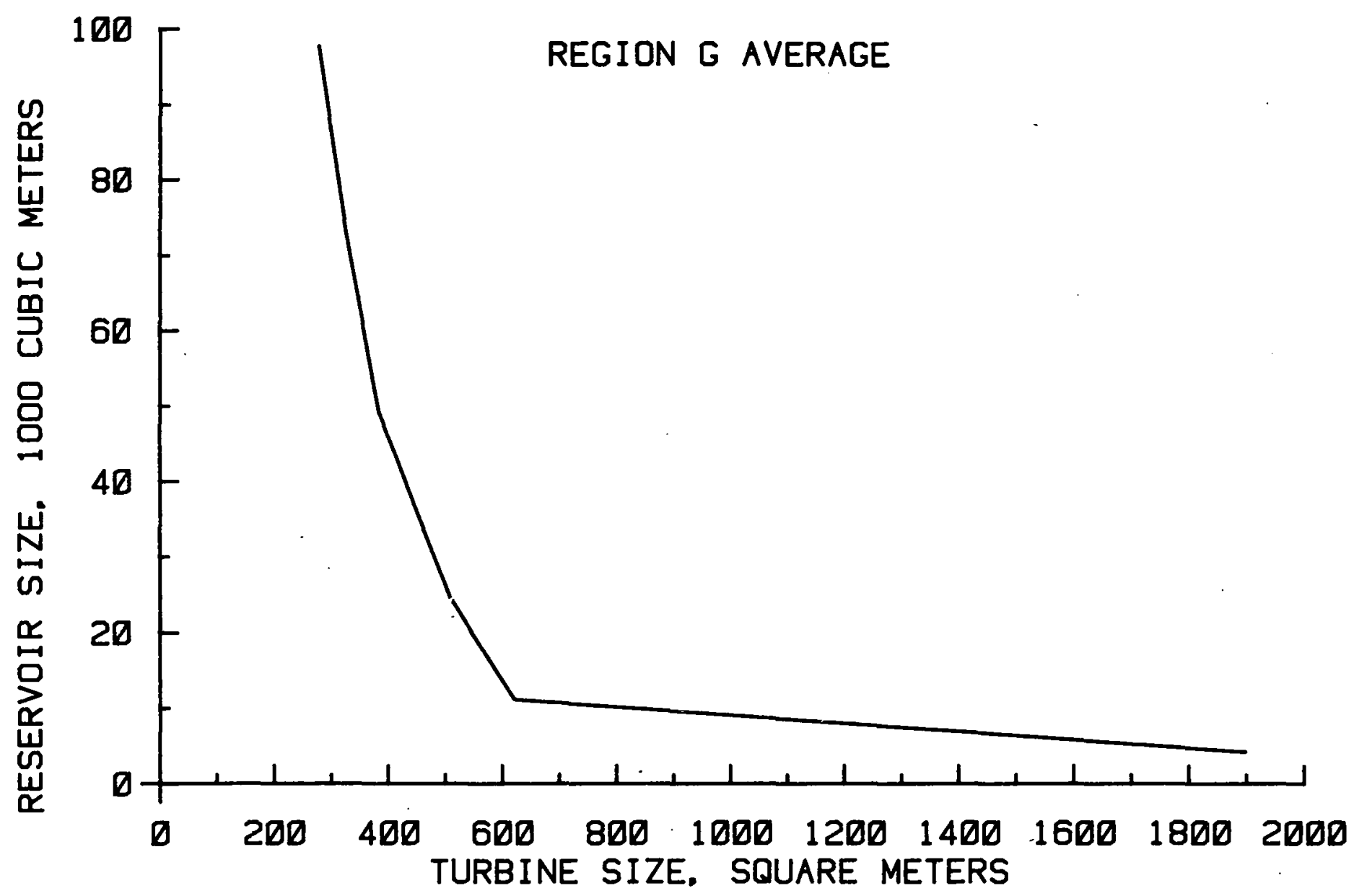

Figure A-7. Turbine size versus reservoir size - Region G. 


\section{THIS PAGE}

\section{WAS INTENTIONALLY LEFT BLANK}




\section{APPENDIX B}

Breakeven Investment Values, Wind Assist Without Sale of Surplus Electricity 

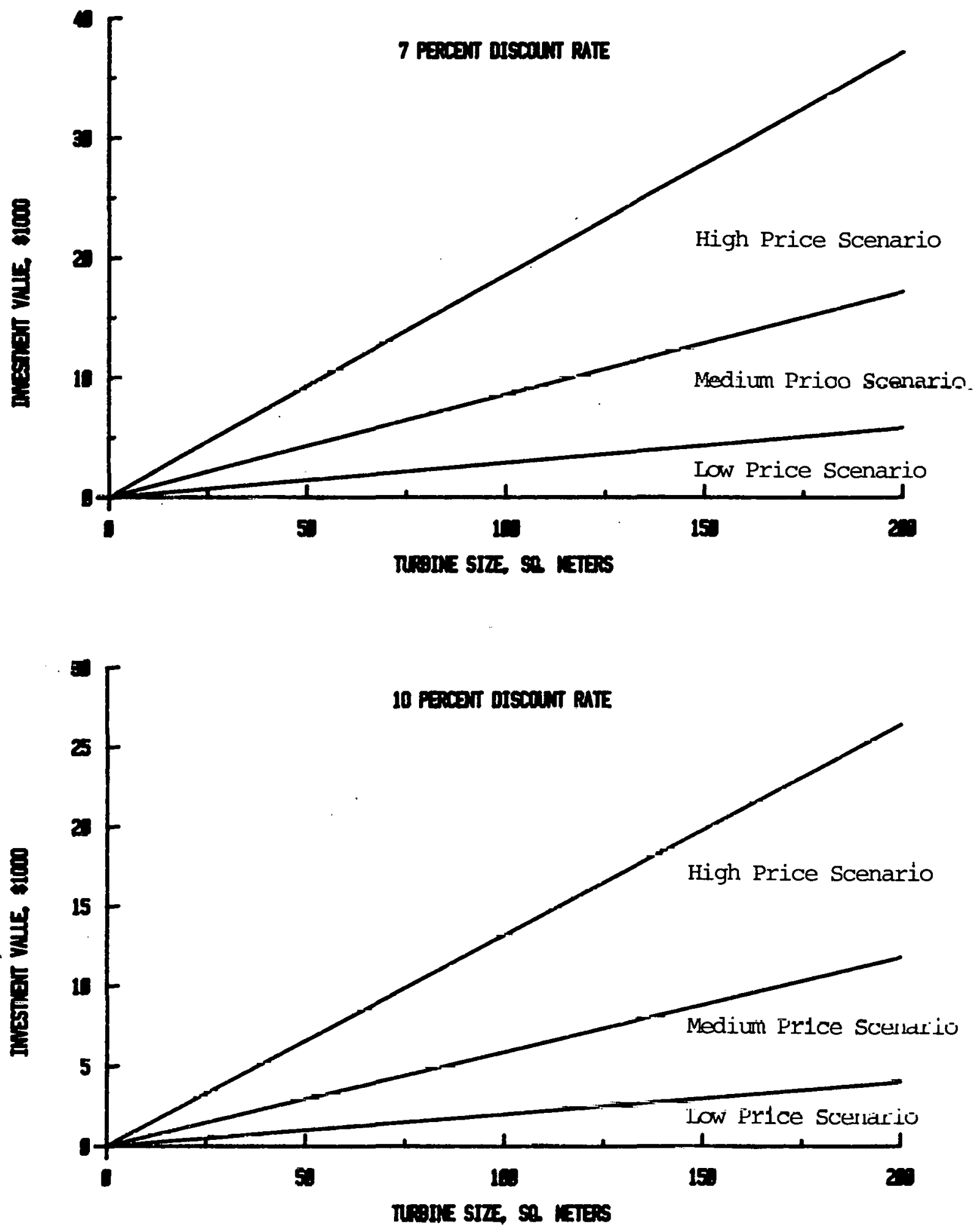

Figure B-1. Breakeven investment. value (1980 dollars) by turbine size for diesel by energy price scenario, wind assist without sale of surplus electricity, Region A. 

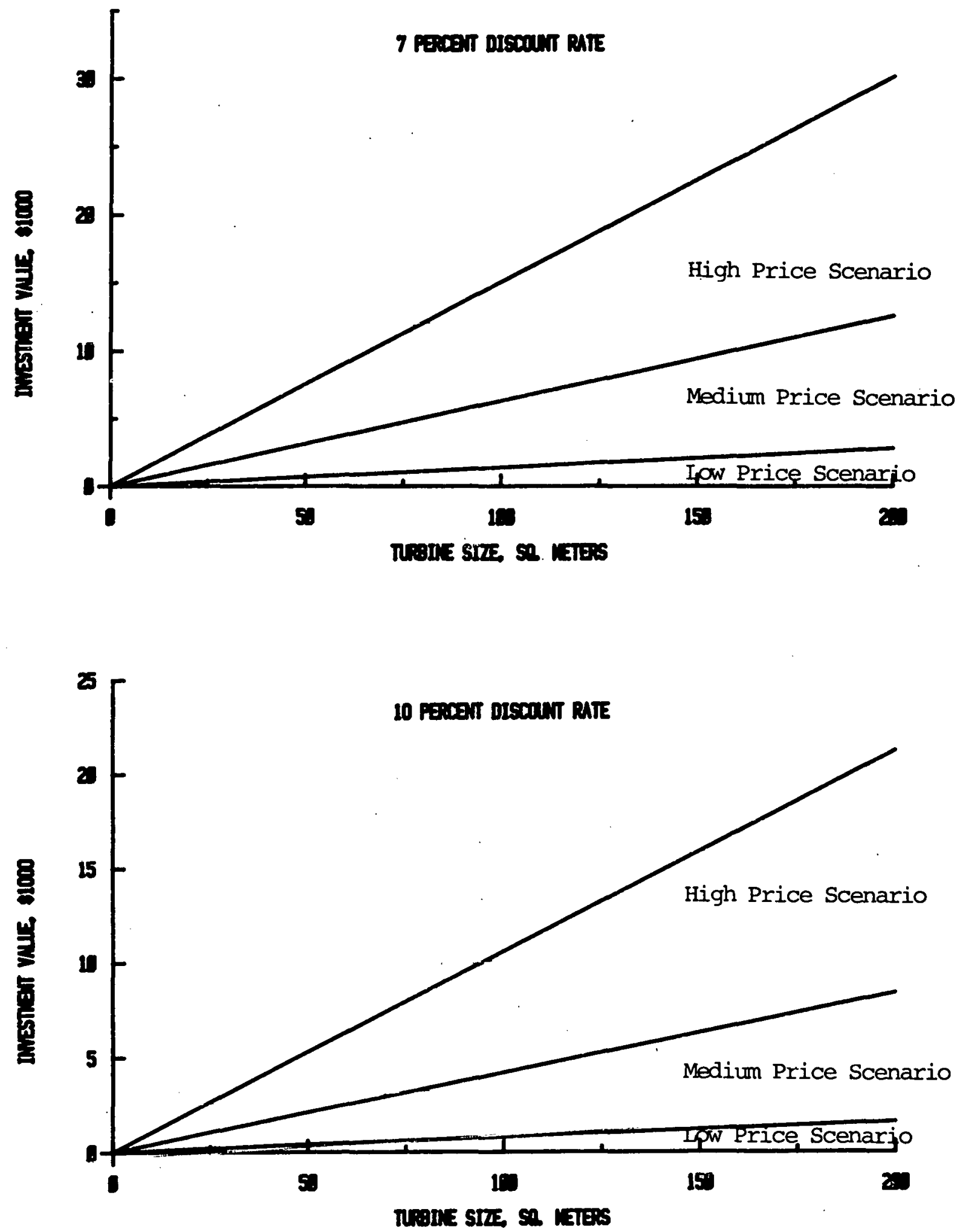

Figure B-2. Breakeven investment value (1980 dollars) by turbine size for IPG by energy price scenario, wind assist without sale of surplus electricity, Region A. 

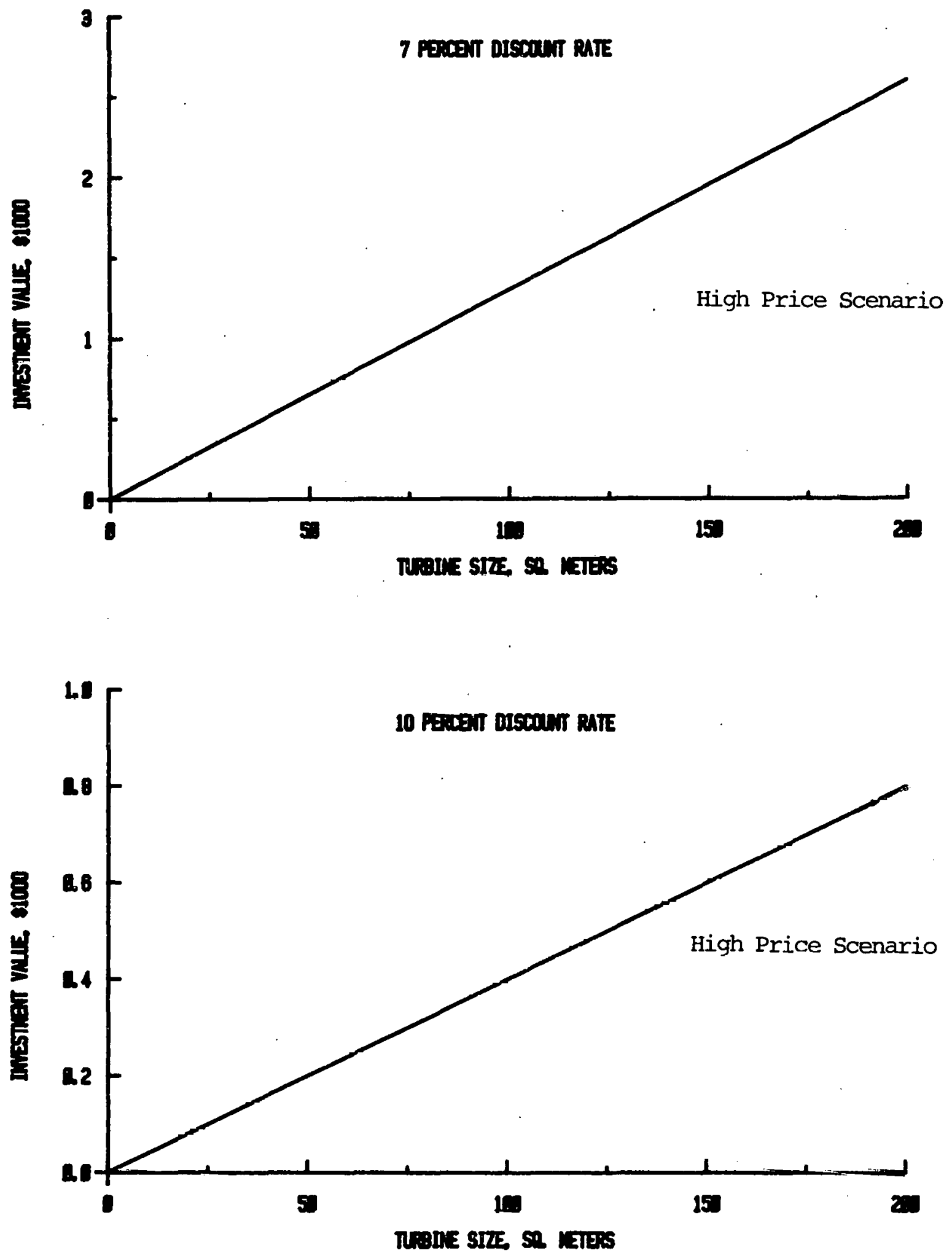

Figure B-3. Breakeven investment value (1980 dollars) by turbine size for natural gas by energy price scenario, wind assist without sale of surplus electricity, Region A. 

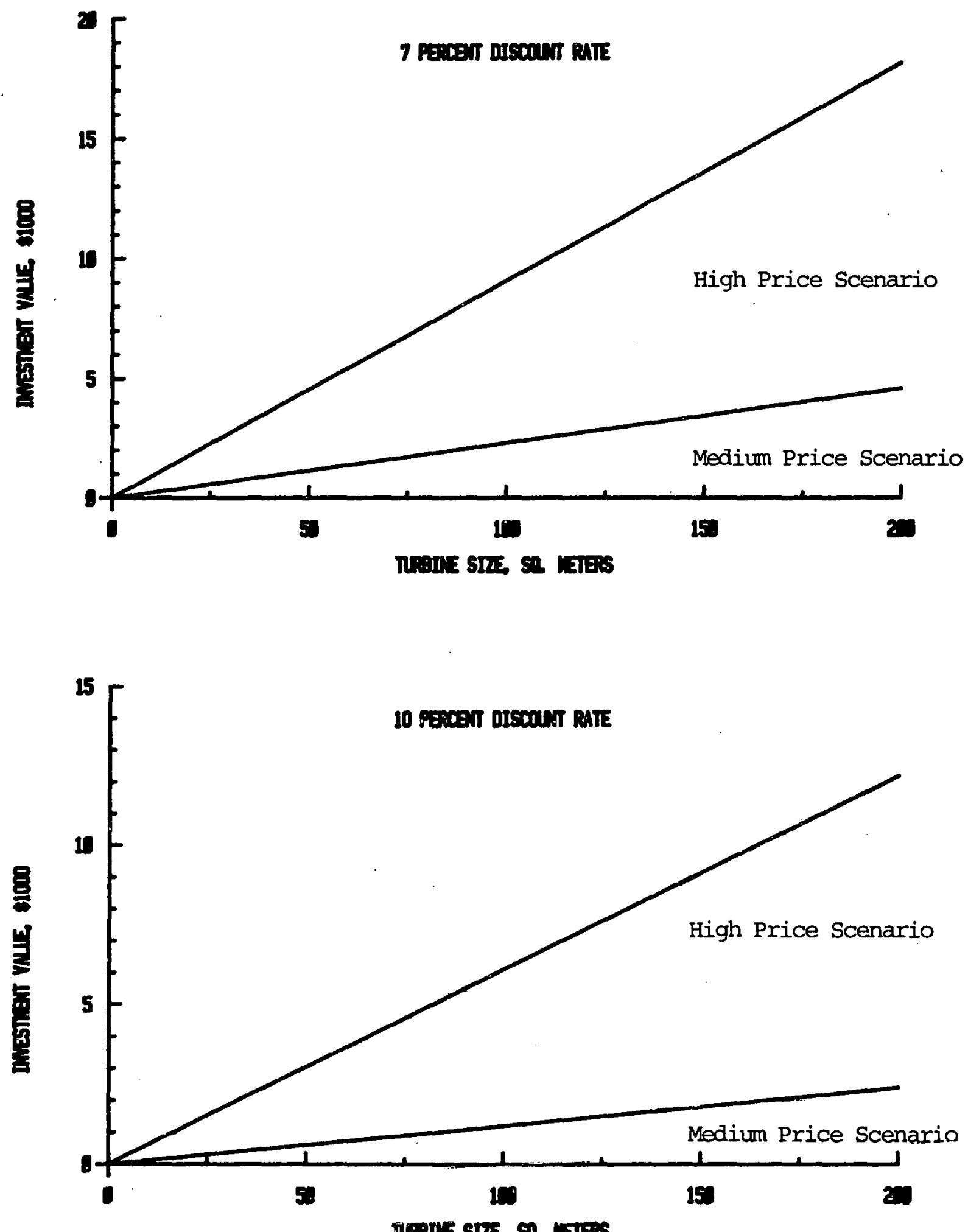

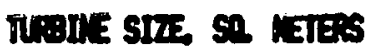

Figure B-4. Breakeven investment. value (1980 dollars) bv turbine size for diesel by energy price scenario, wind assist without sale of surplus electricity, Region B. 

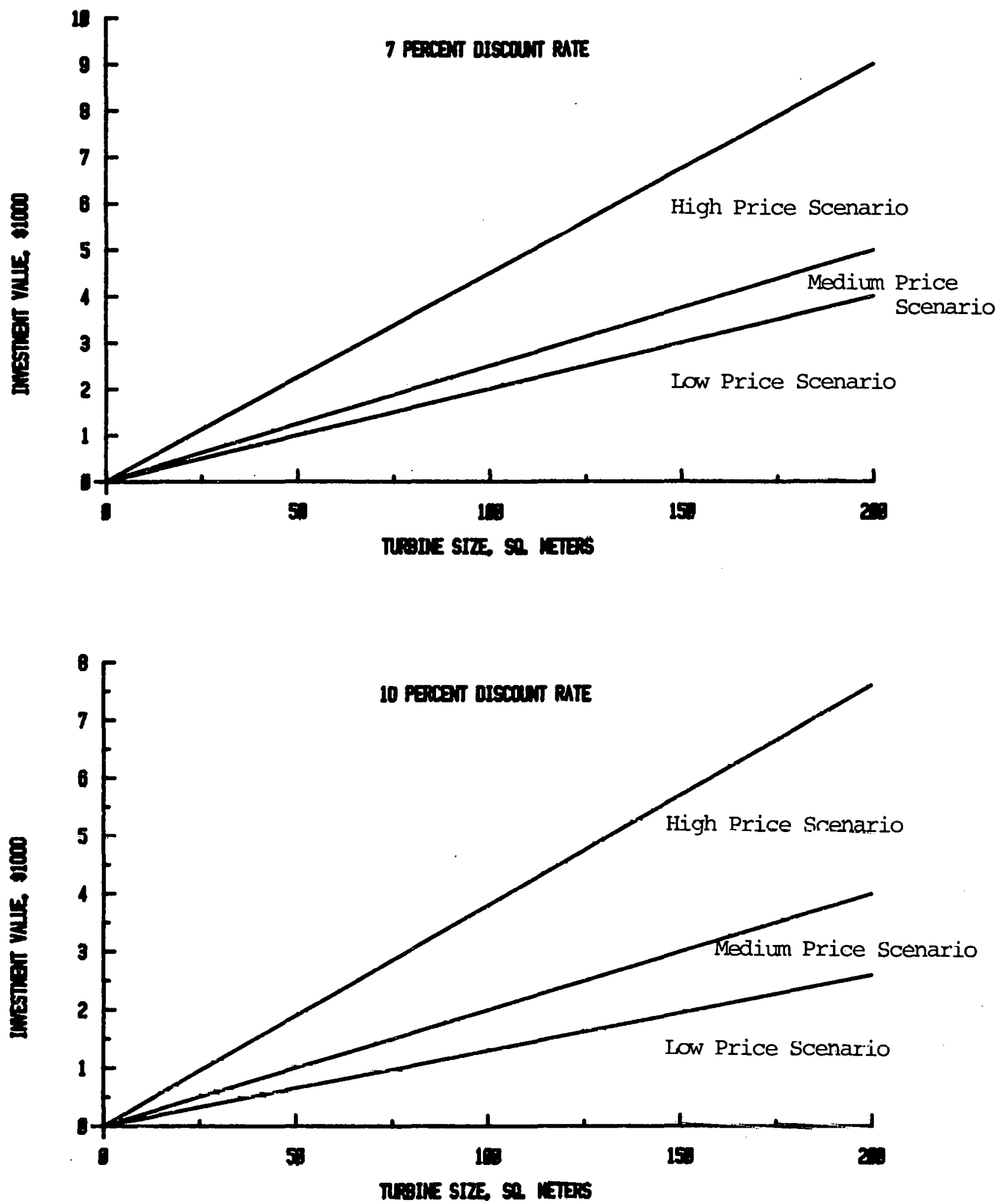

Figure B-5. Breakeven investment value (1980 dollạrs) by turbine size for natural gas by energy price scenario, wind assist without sale of surplus electricity, Region D. 
APPENDIX C

Breakeven Investment Values, Wind Assist

With Sale of Surplus Electricity 

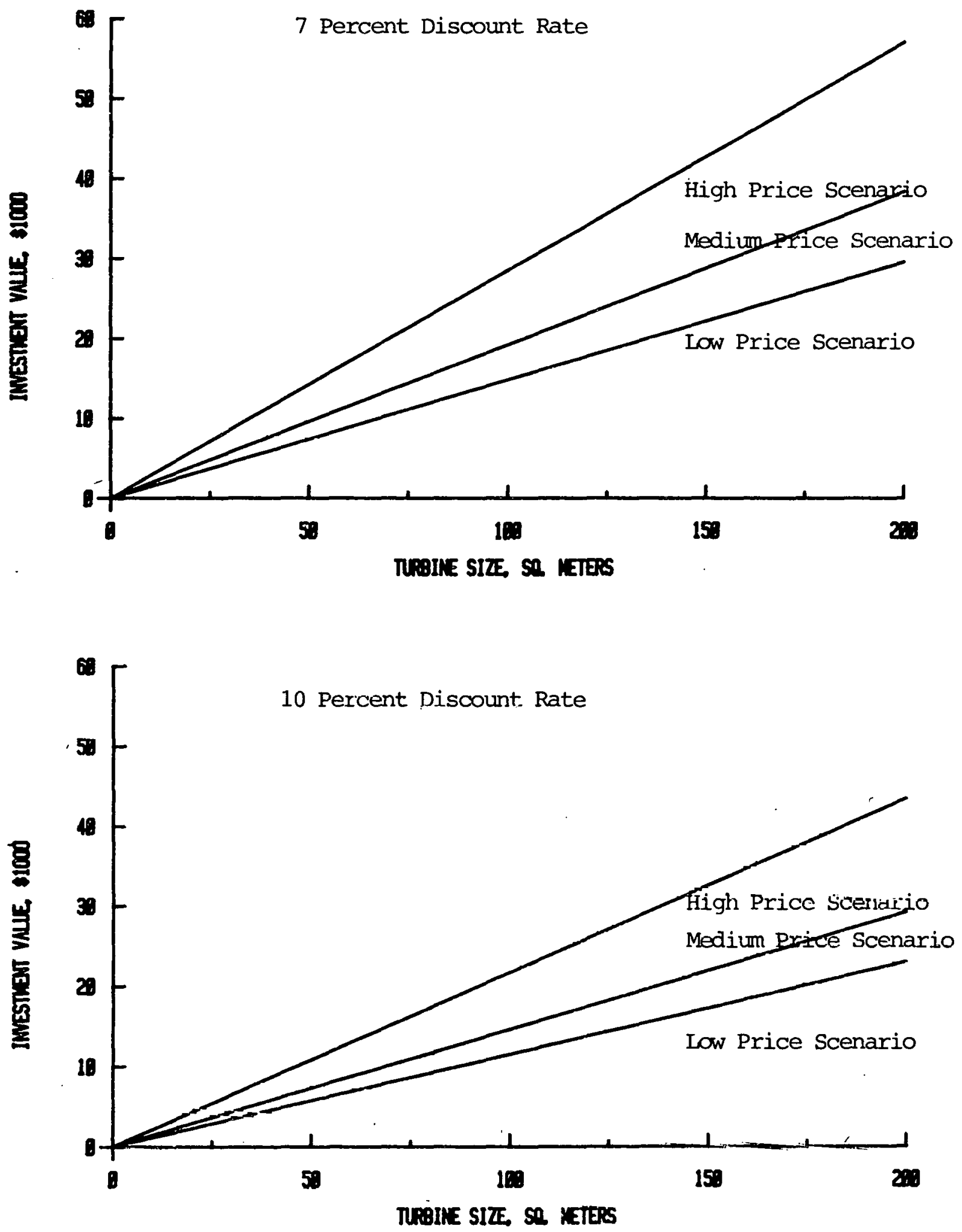

Figure C-1. Breakeven investment value (1980 dol 1.ars) by turbine size for electricity by energy price scenario, wind assist with sale of surplus electricity, Region A. 

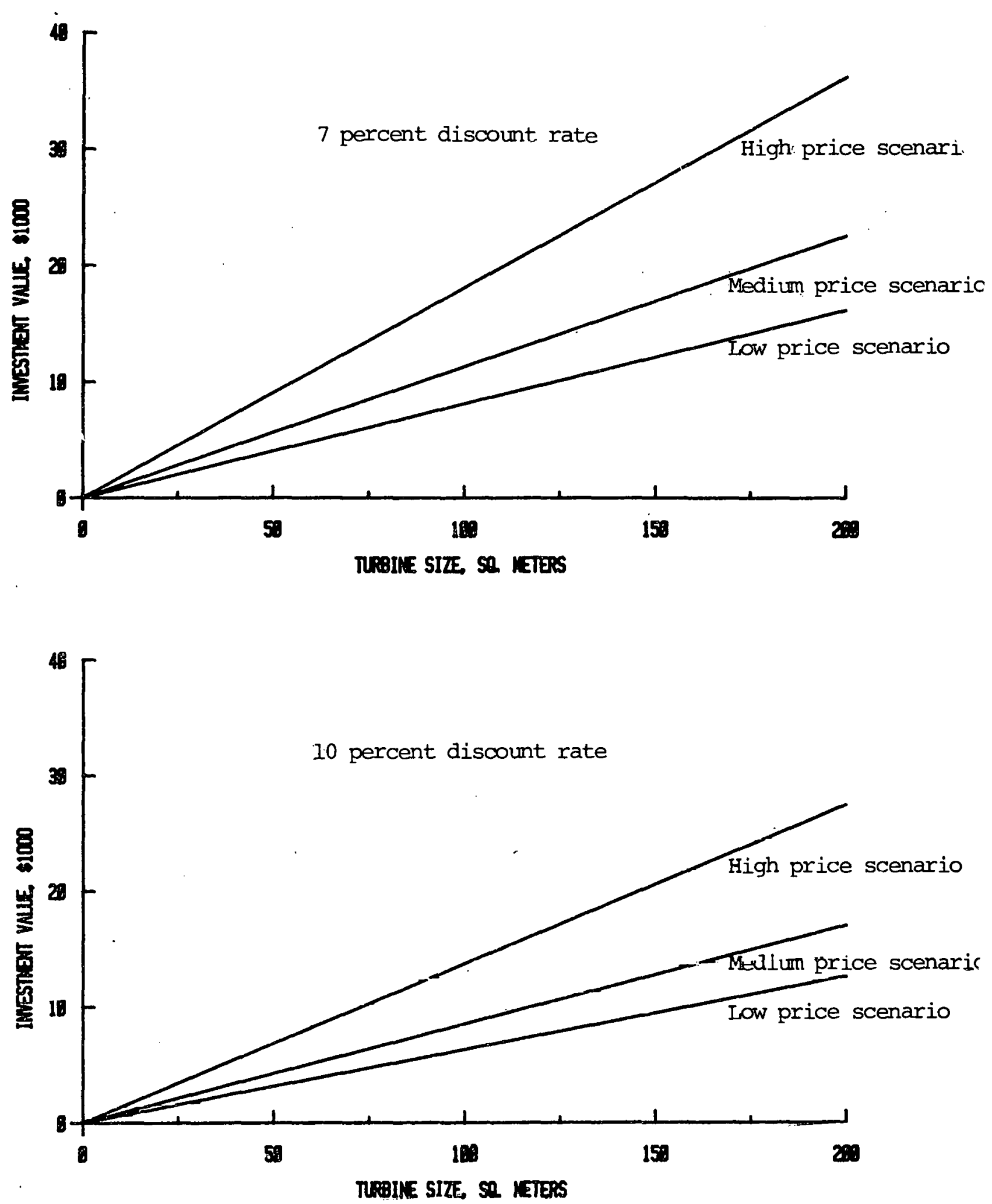

Figure C-2. Breakeven investment value (1980 dollars) by turbine size for electricity by energy price scenario, wind assist with sale of surplus electricity, Region $B$. 

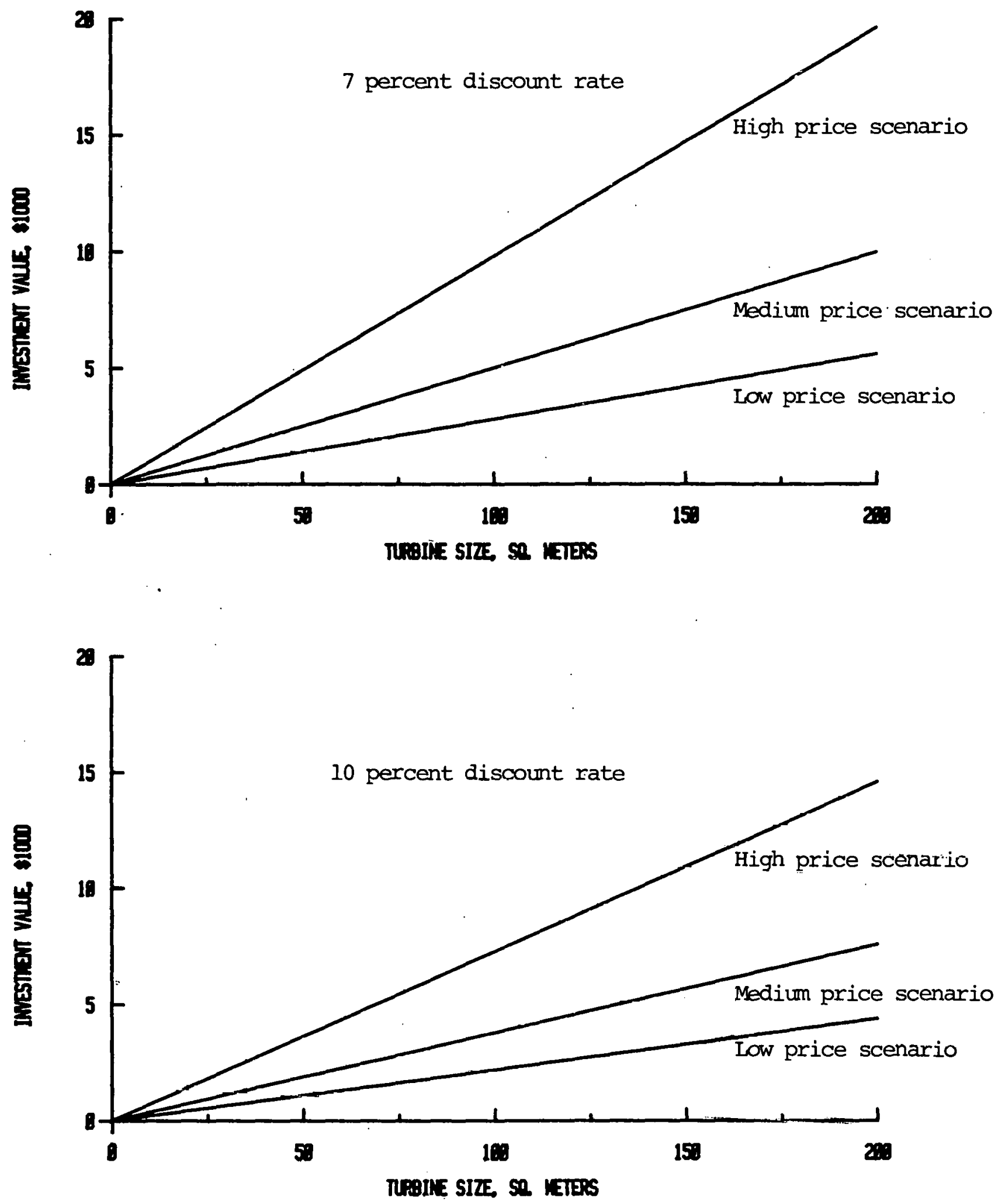

Figure C-3. Breakeven investment value (1980 dollars) by turbine size for electricity by energy price scenario, wind assist with sale of surplus electricity, Region $C$. 

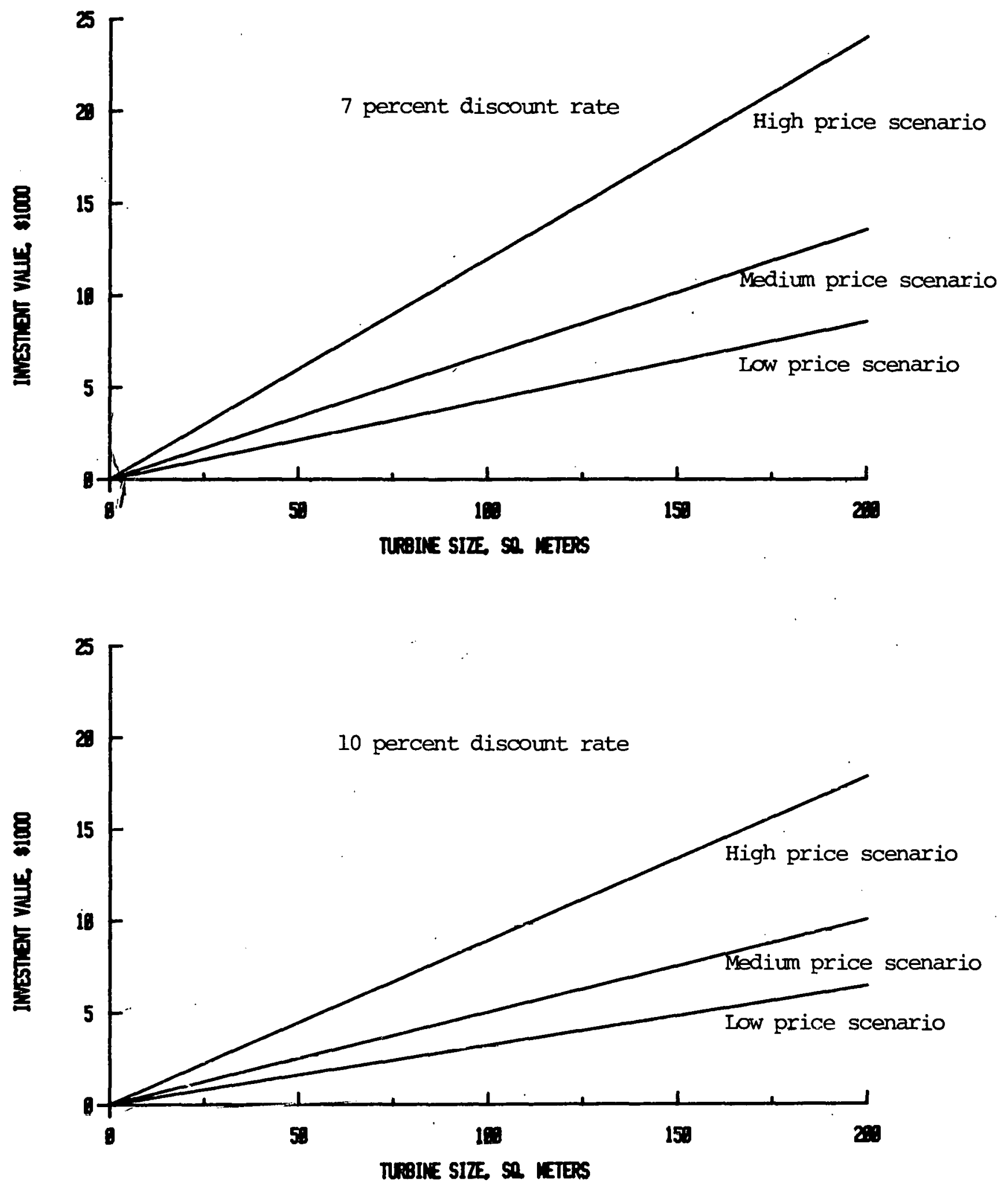

Figure C-4. Breakeven investment value (1980 dollars) by turbine size for electricity by energy price scenario, wind assist with sale of surplus electricity, Region D. 

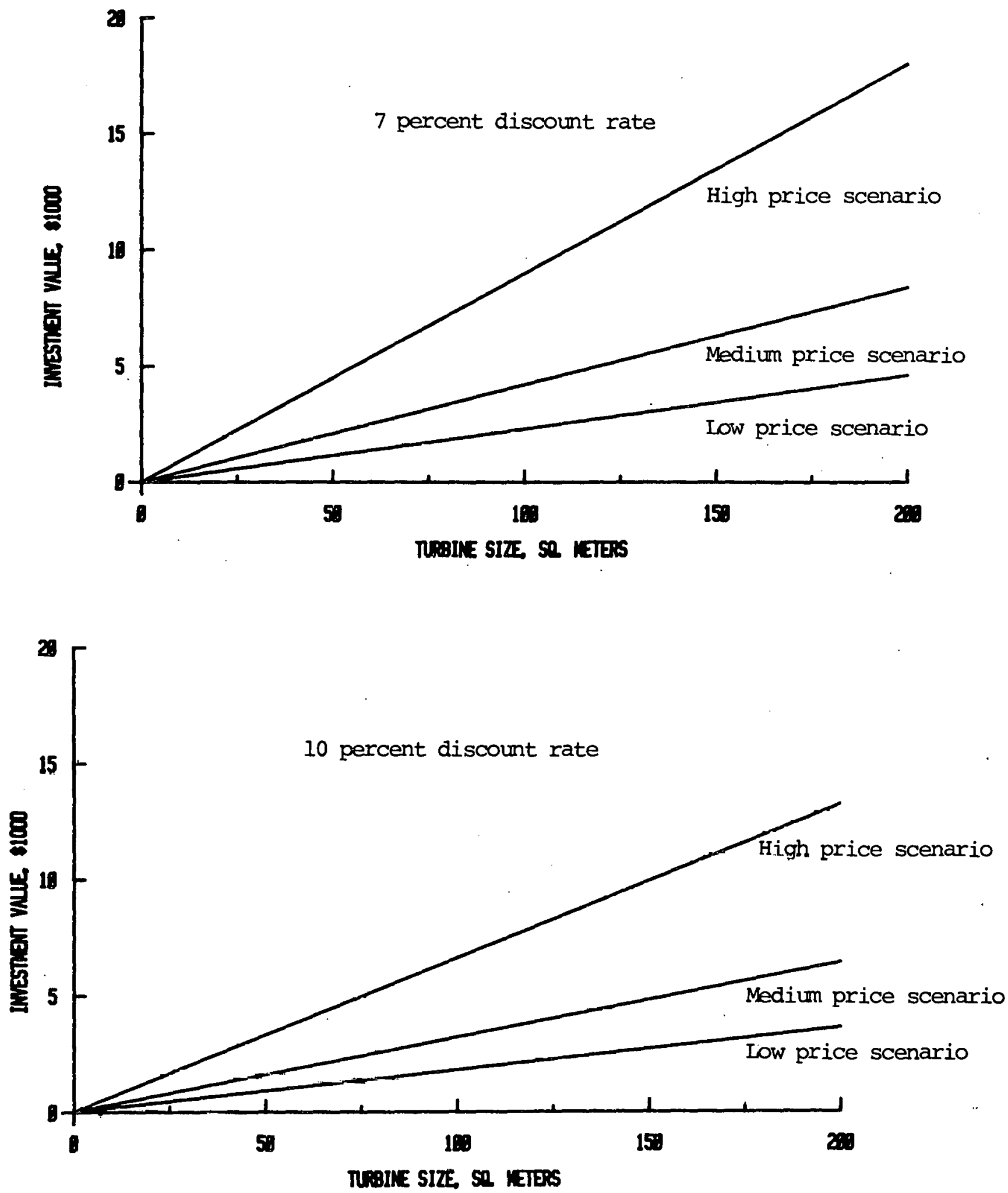

Fiqure C-5. Breakeven investment value (1980 dollars) by turbine size for electricity by energy price "cenario, wind assist with sale of surplus electricity, Region E. 

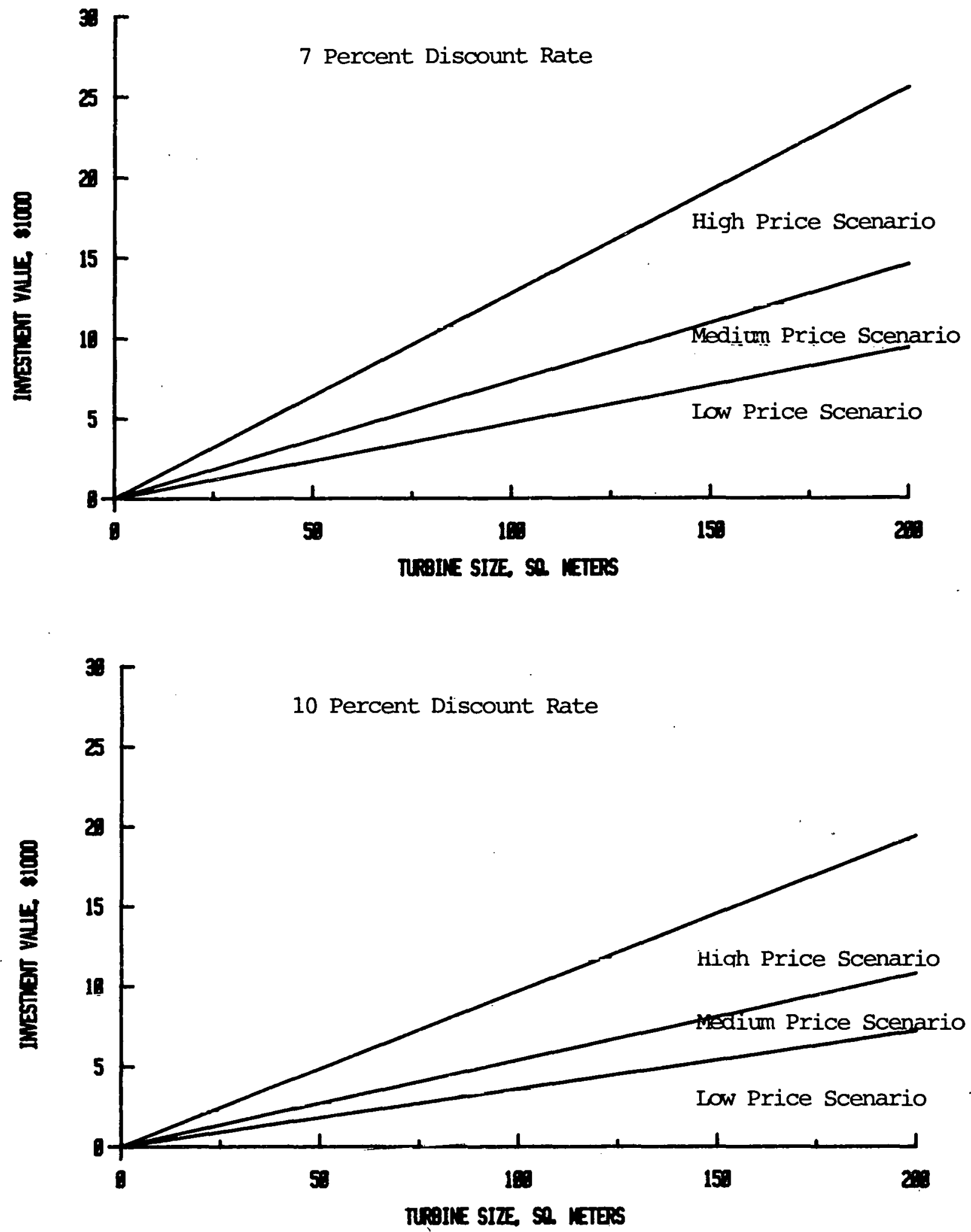

Figure C-6. Breakeven investment value (1980 dollars) by turbine' size for electricity by energy price scenario, wind assist with sale of surplus electricity, Region F, 

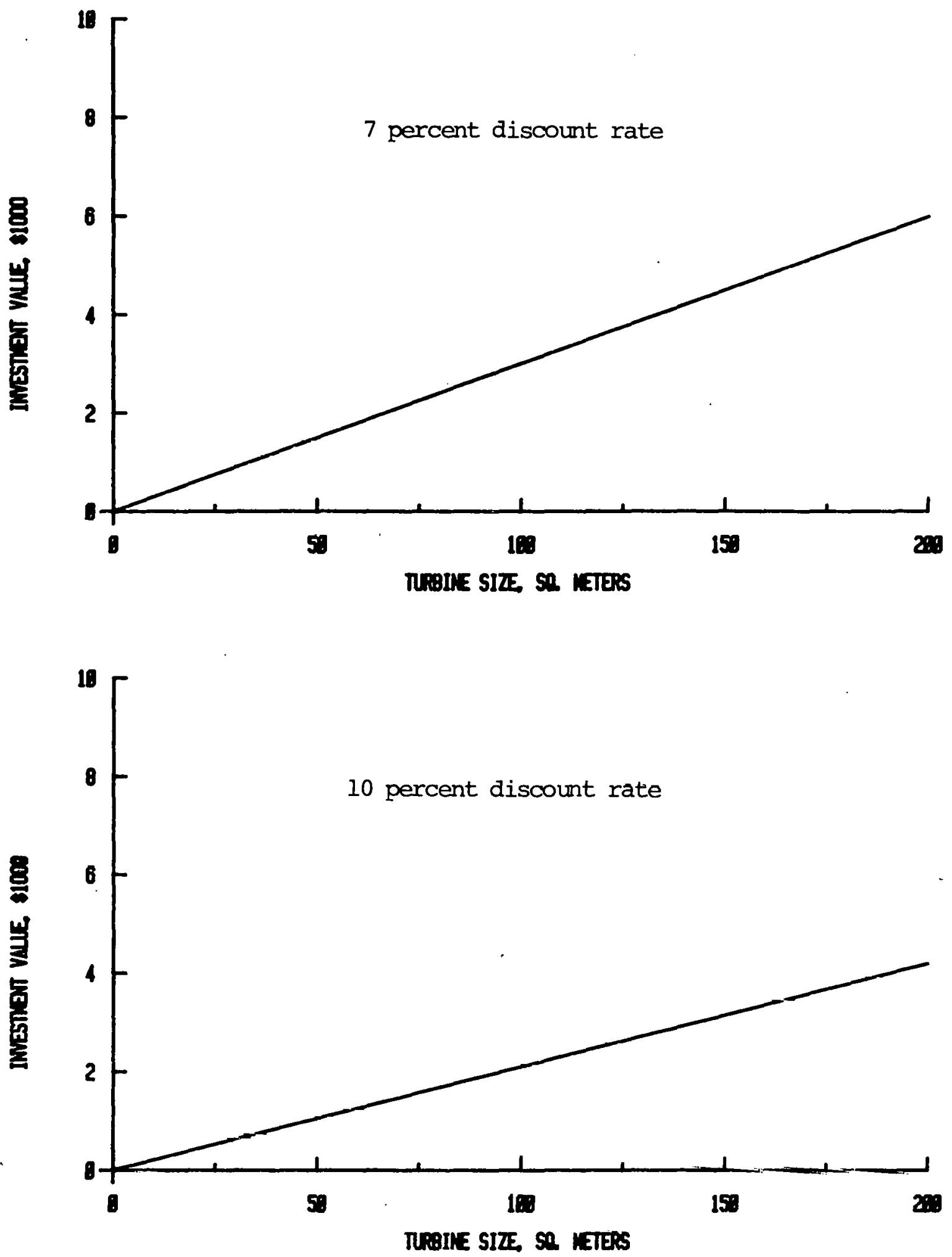

Figure C-7. Breakeven investment value (1980 dollars) by turbine size for electricity by energy price scenario, wind assist with sale of surplus electricity, Region G. 
APPENDIX D

Breakeven Investment Values, Stand Alone Systed 

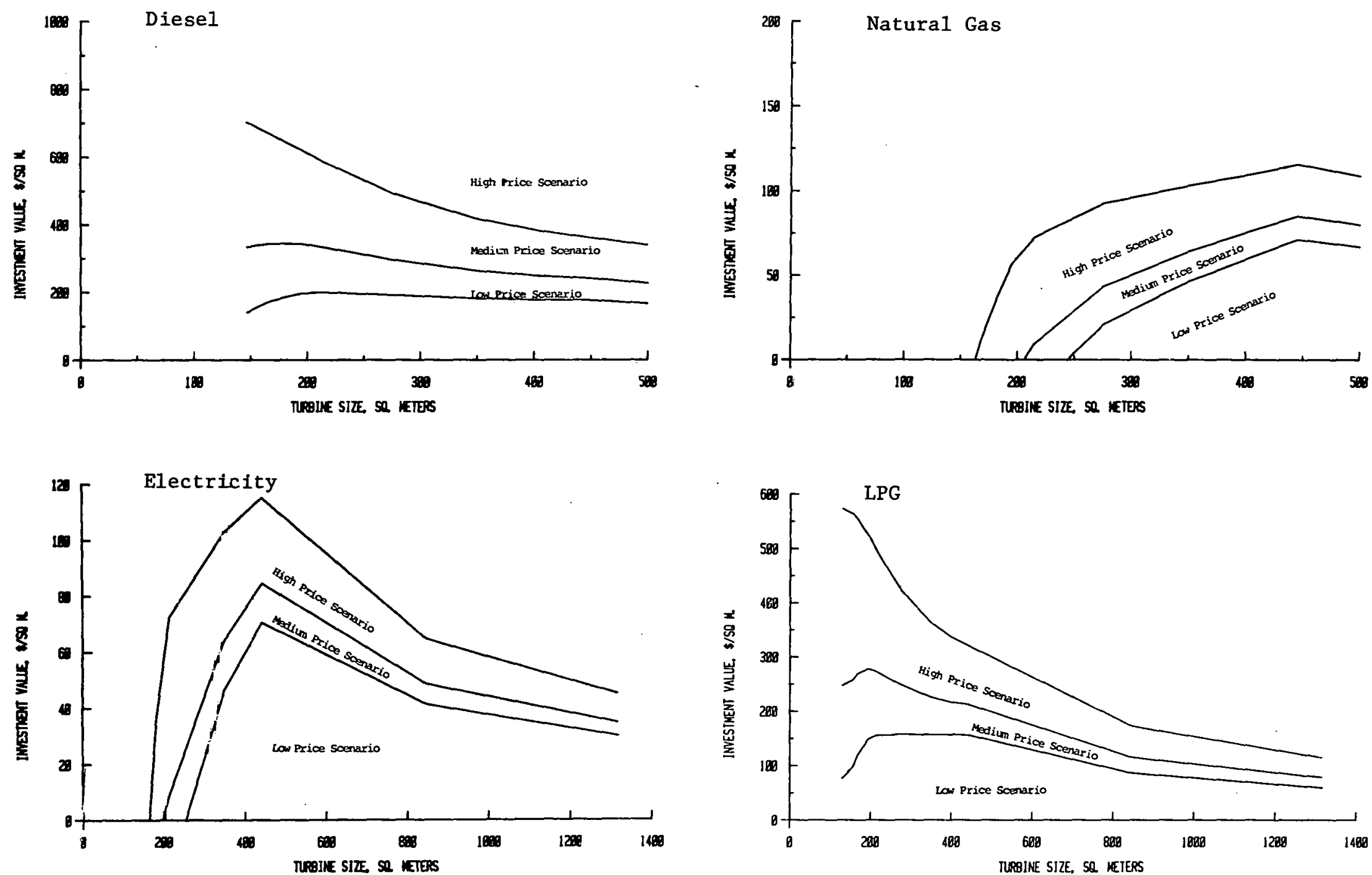

Figure D-1. Breakeven investment value (1980 dollars) by turbine size and energy source, by energy price scenario, stand alone system, Region A. 

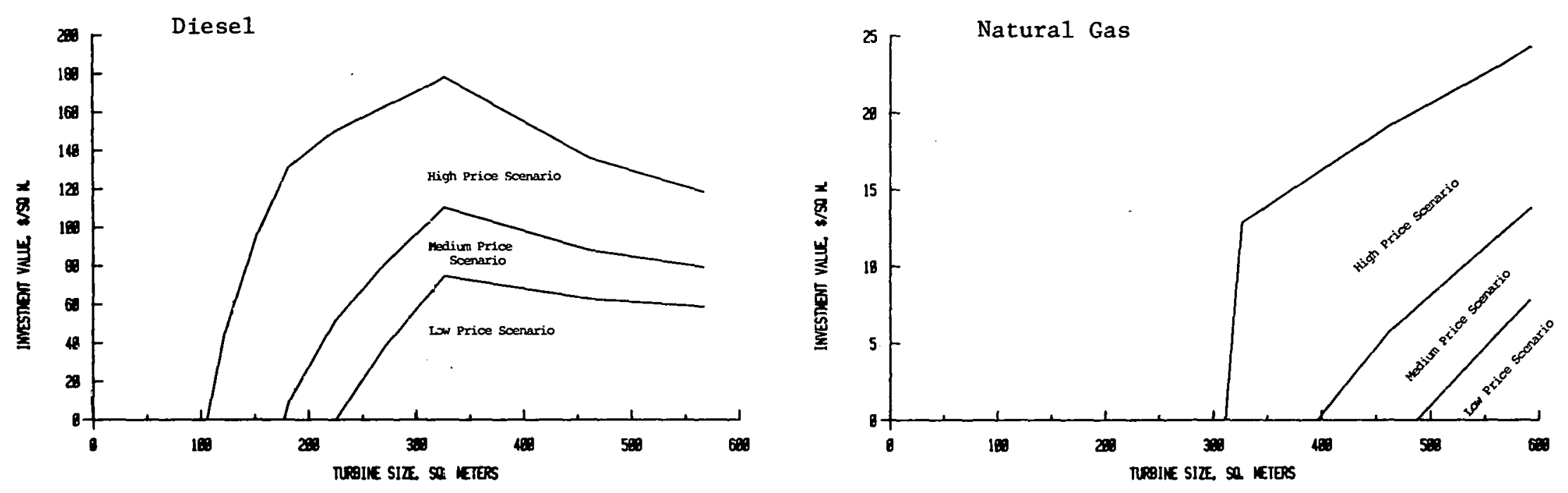

$\vec{v}$

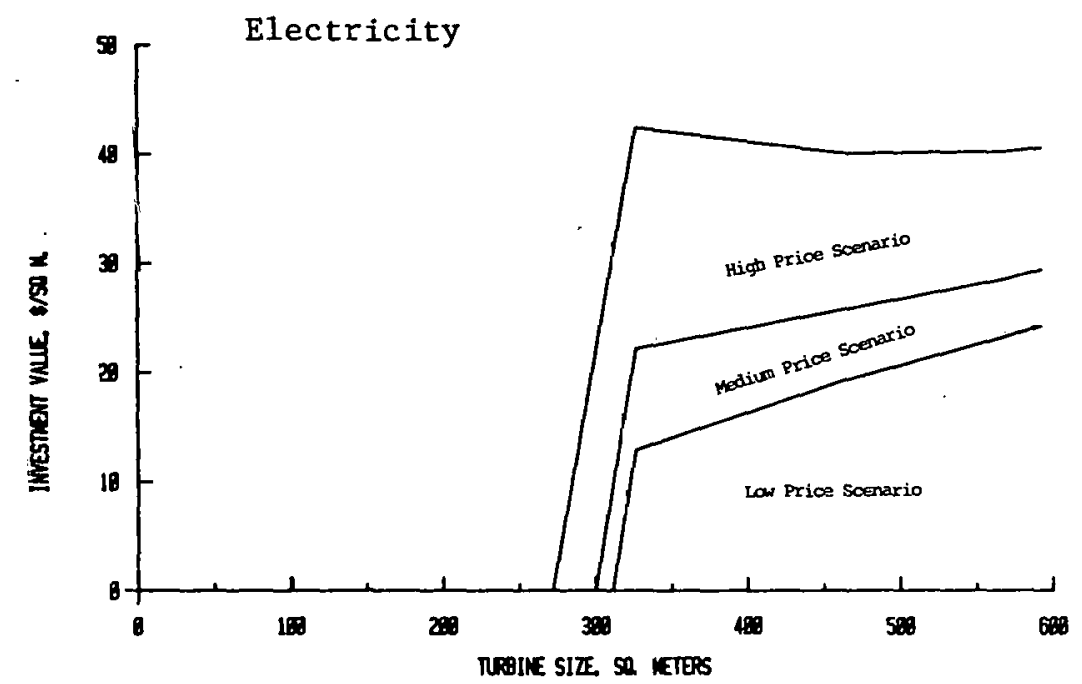

Figure D-2. Breakeven investment value (1980 dollars) by turbine size and energy source, by energy price scenario, stand alone system, Region $B$. 

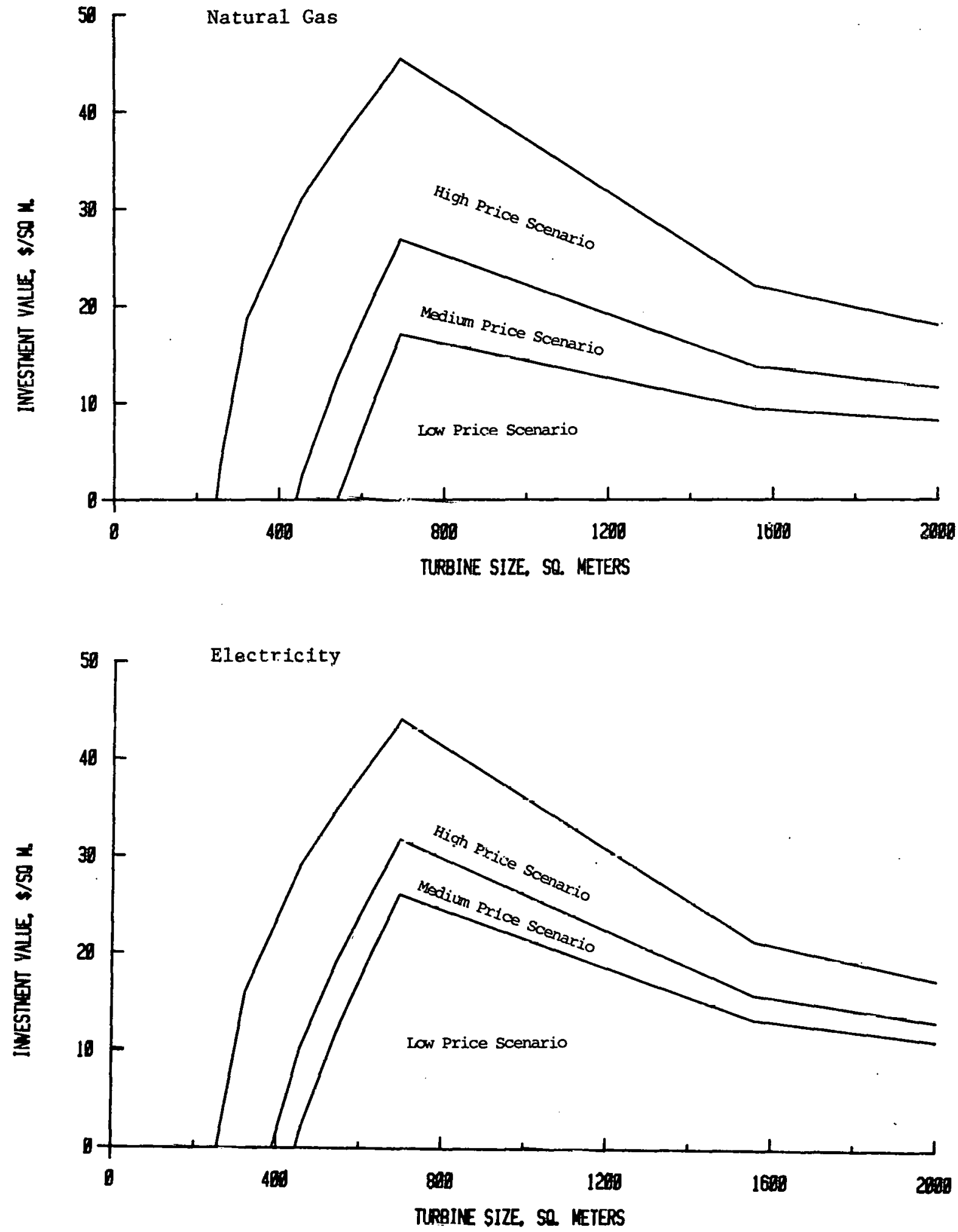

Figure D-3. Breakeven investment value (1980 dollars) by turbine size and energy source, by energy price scenario, stand alone system, Region C. 


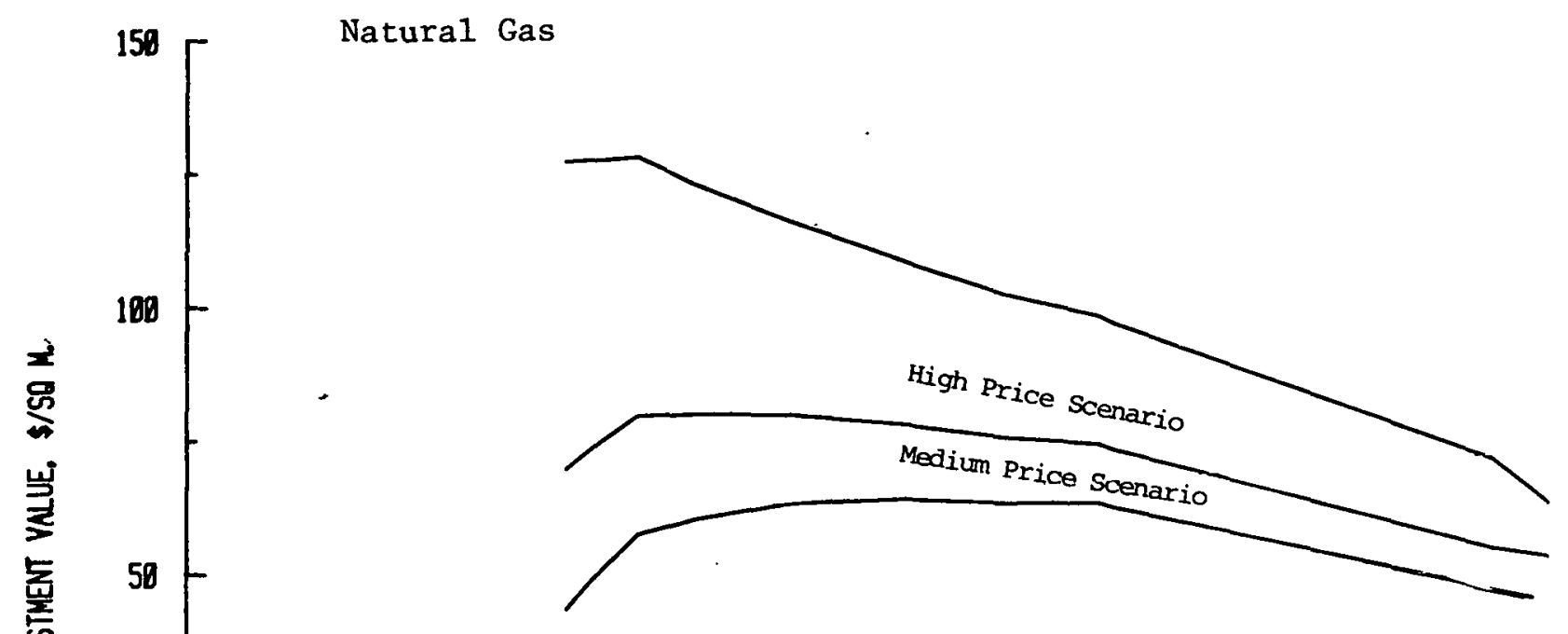

Low Price Scenario

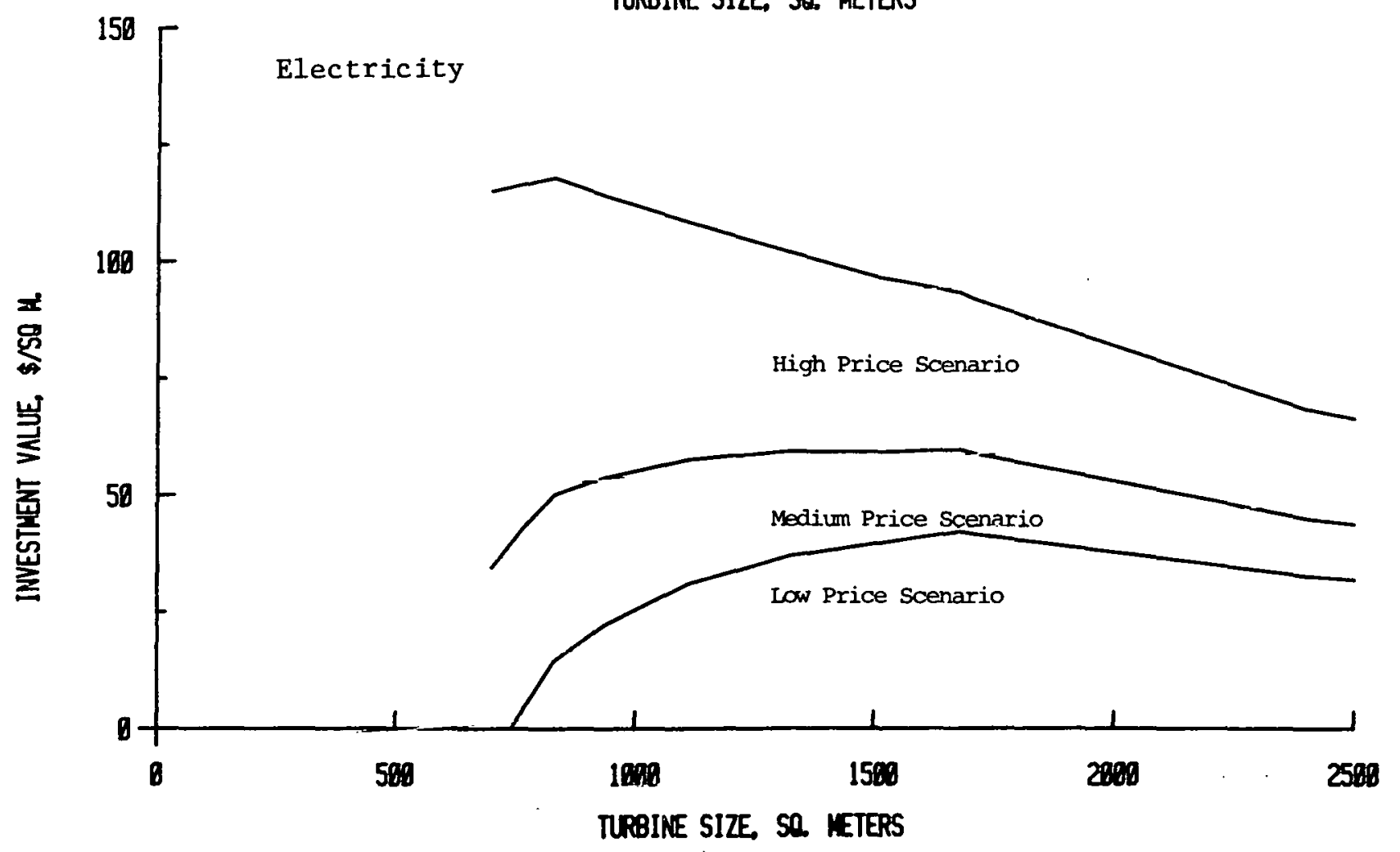

Figure D-4. Breakeven investment value (1980 dollars) by turbine size and energy source, by energy price scenario, stand alone system, Region $D$. 


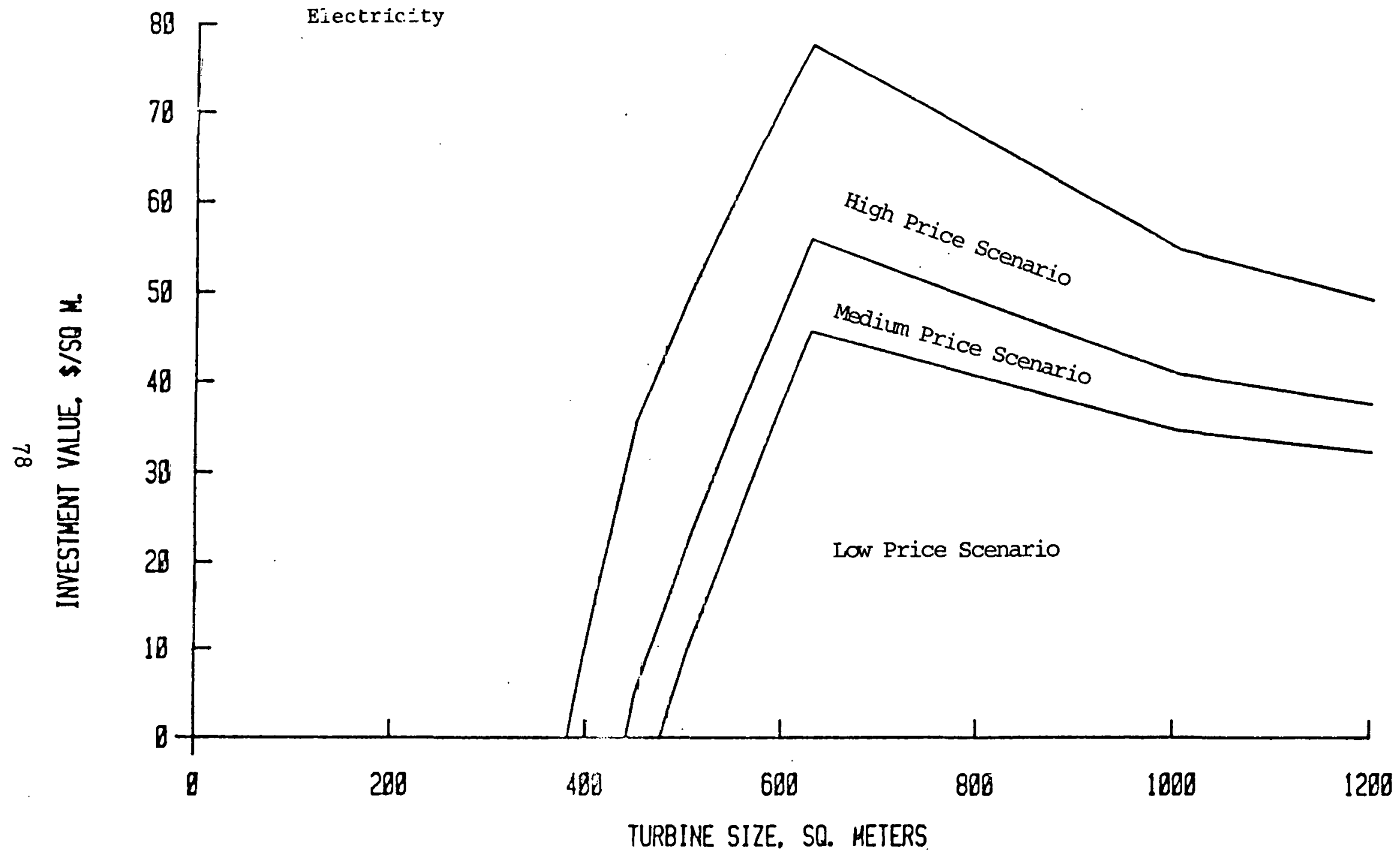

Figure D-5. Breakeven investment value (1980 dollars) by turbine size for electricity, by energy price scenario, stand alone system, Region E. 

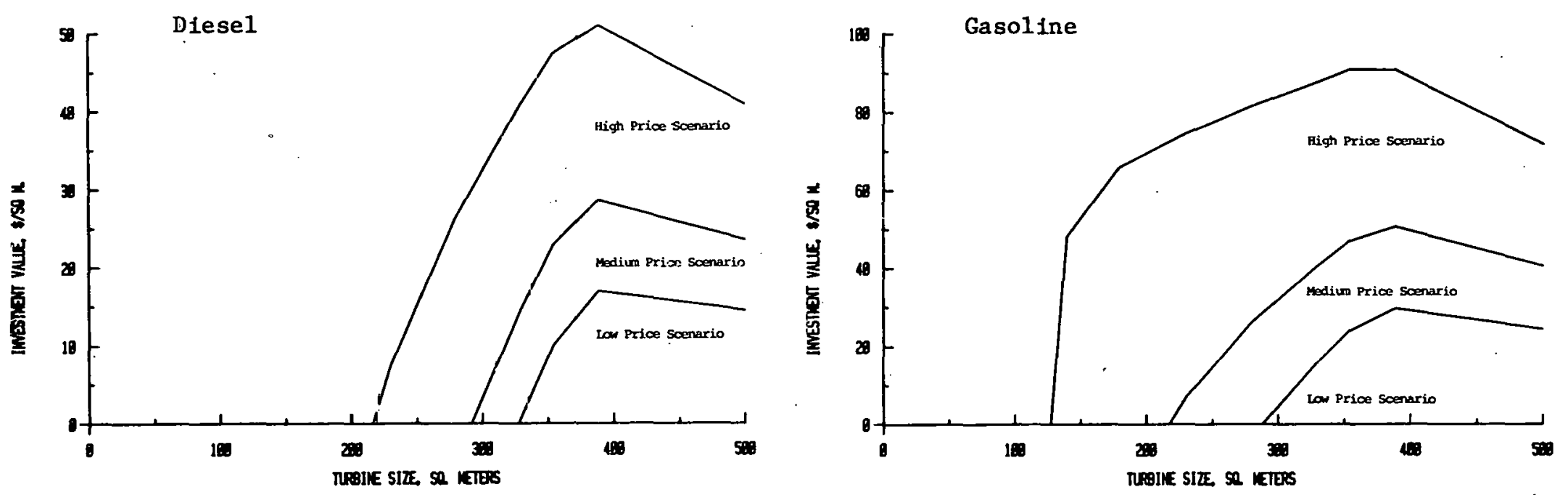

ஸี

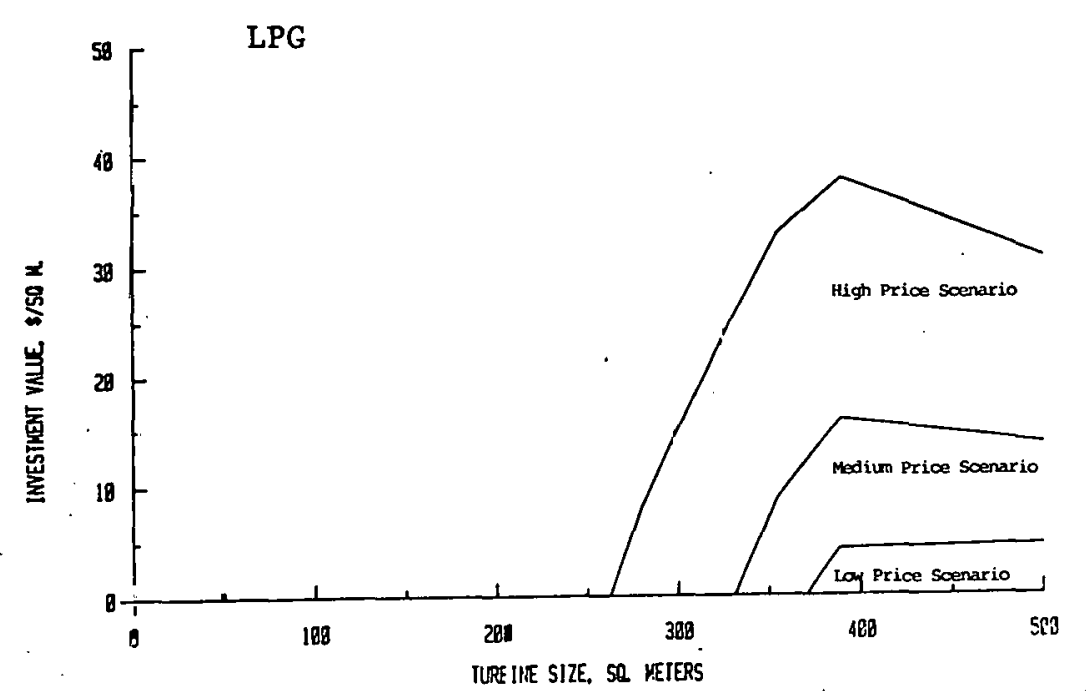

Figure D-6. Breakejen investment value (1980 dollars) by turbine size and energy source, by energy price scenario, stand alone, system, Region F. 


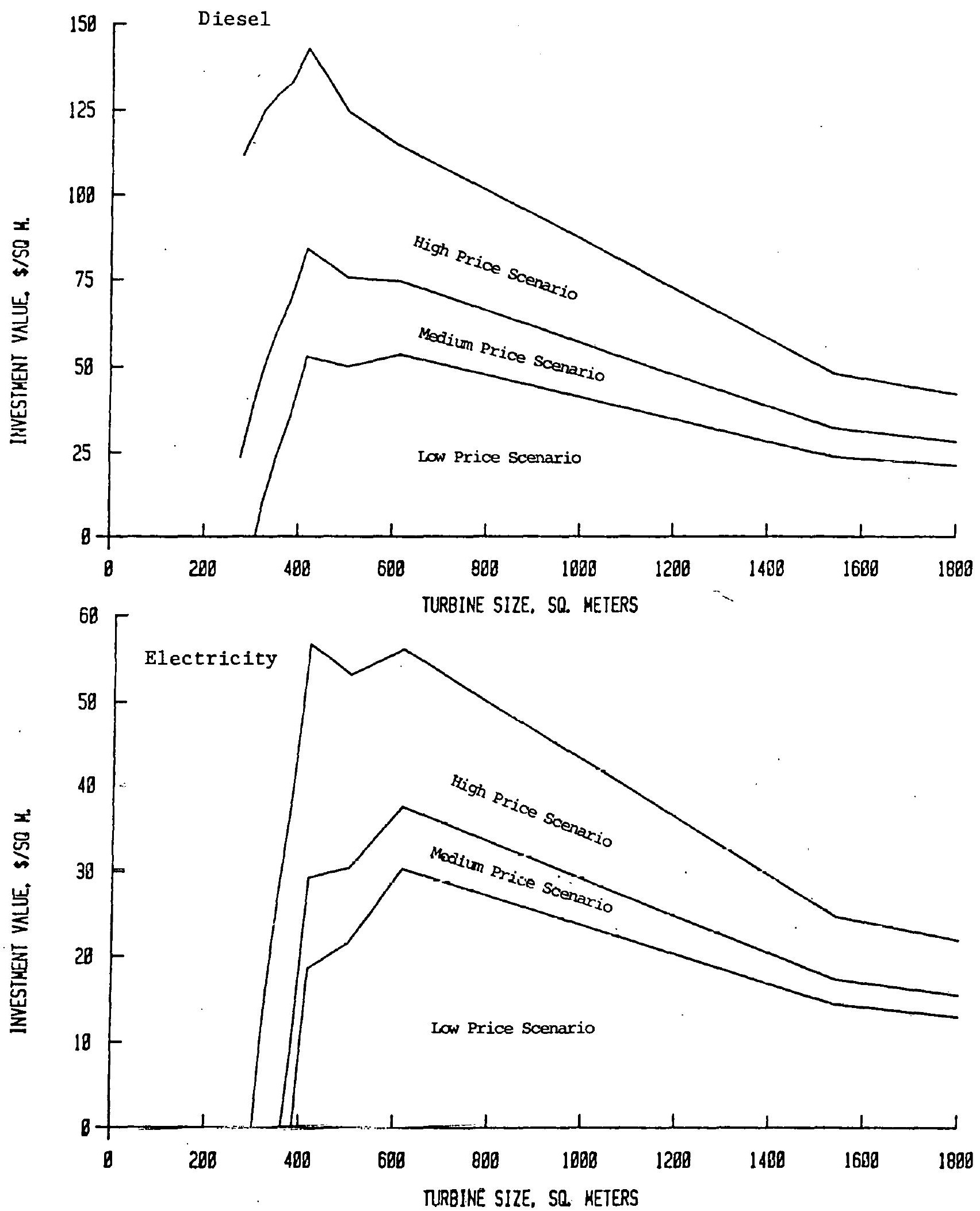

Figure D-7. Breakeven investment valuc (1980 dullars) by turbine size and energy source, by energy price scenario, stand alone system, Region G. 
* U.S. GOVERNMENT PRINTING OFFICE: 1981- 771-039/33B 